\title{
AN ASSESSMENT OF LATE PLEISTOCENE TO MIDDLE HOLOCENE LAKE LEVEL FLUCTUATIONS IN SURPRISE VALLEY, CALIFORNIA
}

\author{
AN HONORS THESIS \\ SUBMITTED TO THE \\ DEPARTMENT OF GEOLOGICAL AND ENVIRONMENTAL \\ SCIENCES \\ OF STANFORD UNIVERSITY \\ IN PARTIAL FULFILLMENT OF THE REQUIREMENTS \\ FOR THE DEGREE OF \\ BACHELOR OF SCIENCE WITH HONORS
}

Daniel Enrique Ibarra

June 2012 
Approved for the Department:

I certify that I have read this thesis and that, in my opinion, it is fully adequate in scope and quality as a thesis for the degree of Bachelor of Science with Honors.

Kate Maher

Principle Advisor

I certify that I have read this thesis and that, in my opinion, it is fully adequate in scope and quality as a thesis for the degree of Bachelor of Science with Honors.

Anne E. Egger

Second Reader 


\section{ACKNOWLEDGEMENTS}

I would like to thank my advisor, Professor Kate Maher, for having the confidence in me to set out and plan a senior thesis while also working on our project studying the uranium isotope proxy in soil minerals. Kate has pressed me to delve deeply into the world of isotope geochemistry and geochronology, taught me valuable skills both in the field and back in the laboratory, and challenged me to integrate different disciplines of science into my research. Pursuing a senior thesis in her lab was an intellectually engaging process and an irreplaceable capstone undergraduate research experience.

Professor Anne Egger exhibits constant support, sound advice and sheer passion for science, all of which inspired me to pursue a degree in GES. Anne's knowledge of Surprise Valley was invaluable to this project and it was fitting that I worked on a senior thesis with her after taking my first geology classes from her. I would also like to thank Professor Dennis Bird and Dr. Richard Nevle for their continued advocacy and 'you can do it' message towards all of the Earth Science undergraduates.

I am grateful to all of the members, past and present, of the Environmental Isotope Geochemistry research group - Dr. Jessica Oster, Abe Torchinsky, Miguel Cruz, Cynthia McClain, Pablo Garcia del Real, Kim Lau, Dana Thomas, Aya Schneider-Mor, Valerie Rosen, Claire Kouba, and Joey Nelson - for creating an intellectually stimulating research environment. Additionally, wrapping up this thesis was truly a whirlwind and literarily none of it would have happened without the ICP-MS lab manager Caroline Harris or the clean lab manager Karrie Weaver. In particular, Caroline has been a major part in developing my laboratory and research skills over the last several years.

I would also like to thank Hari Mix, Jeremy Caves, Sverre LeRoy, Mike Osbourne, Danny Naylor, Kevan Moffett, Dr. Dan Horton, Dr. Jessica Oster, Gabriella Faran, Elif Tasar, and Sarah Lummis for thoughtful discussions and editing as my thesis evolved from a proposal to a finished product. Additionally, Guangchao Li and Dave Mucciarone carried out the elemental and stable isotope analyses. Sabina Kraushaar provided field assistance and Dr. Jonathan Glen generously provided the continuous elevation transect data.

I am often inspired by the dedication of the faculty in the School of Earth Sciences and School of Engineering at Stanford to teach thought provoking, challenging and enjoyable classes. The professors that influenced me the most during my time as an undergraduate at Stanford were Page Chamberlain, Leif Thomas, Noah Diffenbaugh, 
Lynn Hildeman (my Atmosphere/Energy Engineering advisor), Mark Jacobson, Karl Knapp, Elizabeth Miller, Wendy Mao, Marty Grove and Jessica Warren.

Finally, I would like to thank my family, and friends for their support, encouragement and loyalty throughout the last four years. Sarah Lummis, Zach Ming, Jason Gonazalez, Poncie Rutsch, Julia Brownell, Kaz Gunning, Ishan Nath, Allison Fink, Autumn Burnes, Gil Shotan, Stewart Youngblood and Alexander Menke, I am proud to be graduating with you as the Stanford Class of 2012! In particular, I am grateful to Sarah Lummis for being a constant source of encouragement and care on a daily basis. My parents, Dennis and Diana Ibarra, and brother, Eric, have been a steadfast source of strength and inspiration through everything I have chosen to undertake, and I am grateful for their unwavering support despite being on opposite ends of the world.

My work has been funded through a Stanford University Vice Provost for Undergraduate Education Major Grant (2011) and a School of Earth Sciences Summer Undergraduate Research Fellowship (2010). Analytical measurements were supported by NSF EAR-0921134 award to Professor Maher. 


\section{ABSTRACT}

Knowledge of Earth's climate history and sensitivity, combined with modeling past and future climate, are central to informing policy decisions regarding future climate change. The hydrologic response to future warming scenarios due to increased anthropogenic $\mathrm{CO}_{2}$ emissions remains uncertain. Freshwater availability in the arid western United States is projected to decrease in availability as increased agricultural, urban and industrial uses continue to stress supplies. Motivated by the potential for dramatic future hydrologic changes, studies recording the abrupt transitions between different equilibrium states of natural past climate variability shed light on our understanding of the modern climate system.

The presence of pluvial lakes in the Basin and Range Province, in the western United States, during the late Pleistocene (40 to $10 \mathrm{ka}$ ) indicates far greater moisture availability during the Pleistocene glacials. This study investigates the timing and magnitude of the most recent pluvial lake cycle that filled Surprise Valley, California using geophysical, geochemical and geochronologic tools. Spanning 31.2 to $4.6 \mathrm{ka}$, this new lake level record places the highest lake level, at 180 meters above present day playa, at $13.9 \pm 1.2 \mathrm{ka}$. This age appears to be nearly synchronous with highstands of Lake Lahontan to the south and the Chewaucan Basin to the north. Additionally, most of the Basin and Range lake highstands, including Lake Surprise, follow peaks in precipitation minus evapotranspiration (P-ET) by 8-10 kyr. By compiling a diverse set of paleoclimate data available for western North America, I found that the timing and geographic distribution of lake highstands is inconsistent with increased precipitation in response to shifting westerly winds, the current model for the genesis of large lakes in western North America. Rather, lakes levels are more strongly correlated with changes in summer insolation, suggesting that lake highstands were likely facilitated by colder temperatures and increased humidity due to the presence of continental ice sheets and increased atmospheric convergence. I compared the constraints from lake and soil-based records to Atmosphere-Ocean General Circulation Model simulations from the Paleoclimate Model Intercomparison Project 2. Based on model-proxy intercomparison, the Atmosphere-Ocean General Circulation Models, the same models used to also assess future climatic changes, poorly predict hydrologic quantities for the Last Glacial Maximum. 


\section{TABLE OF CONTENTS}

ACKNOWLEDGMENTS

ABSTRACT

1. INTRODUCTION

2. BACKGROUND

2.1 Late Pleistocene Pluvial Lakes in Western North America

2.2 Geologic and Climatic Setting

2.2.1 Surprise Valley, California

2.2.2 Chewaucan Basin, Oregon

$2.3^{230} \mathrm{Th}-\mathrm{U}$ Geochronology

3. METHODS

3.1 Field Methods

3.1.1 Elevation Transects

3.1.2 Sample Collection

3.2 Laboratory Methods

3.2.1 ${ }^{230} \mathrm{Th}-\mathrm{U}$ Geochronology

3.2.1.1 Spike Calibration

3.2.1.2 Sample Dissolution

3.2.1.3 Column Chemistry

3.2.1.4 Isotopic Analyses

3.2.2 $\delta^{18} \mathrm{O}, \delta^{13} \mathrm{C}$ and $\mathrm{Sr} / \mathrm{Ca}$ Analyses

iii

4. RESULTS

4.1 Elevation Transects

$4.2{ }^{230} \mathrm{Th}-\mathrm{U}$ Geochronology

$4.3 \delta^{18} \mathrm{O}, \delta^{13} \mathrm{C}$ and $\mathrm{Sr} / \mathrm{Ca}$ Analyses

5. DISCUSSION

5.1 Assessing Surprise Valley as a Terminal Basin

5.2 Lake Levels of Late Pleistocene To Middle Holocene Lake

Surprise

5.3 Comparison of Results to Existing Lake Records and Other

Paleoclimate Proxy Records

5.4 Global Climate Model and Paleoclimate Records

6. CONCLUSION

7. APPENDICES

7.1 Map of Lake Chewaucan, Oregon Sample Locations 49

7.2 Surprise Valley Watershed Statistics $\quad 50$

7.3 Spike Calibration 51

7.4 Column Chemistry Modified Recipe 54

7.3 Explanation of the Detrital Thorium Age Correction Methods 55

7.6 Elevation Transect Data Tables 56

8. WORKS CITED 


\section{LIST OF FIGURES}

Figure 1. $\quad$ Map of the Western United States with Late Pleistocene Pluvial 3

Figure 2. Maps of the Surprise Valley Watershed and the Primary Study Area 7

Figure 3. Historical Hydrologic and Climate Data for the Surprise Valley 11 Watershed.

Figure 4. Tufa Sample and Field Images $\quad 15$

Figure 5. Surprise Valley Elevation Transect Data $\quad 24$

Figure 6. Isochron Plots Calculating Detrital Corrected Activity Ratios 29

Figure 7. Isochrons $\left(\left({ }^{230} \mathrm{Th} /{ }^{238} \mathrm{U}\right)\right.$ vs. $\left.\left({ }^{234} \mathrm{U} /{ }^{238} \mathrm{U}\right)\right)$ for Surprise Valley Tufa 31

Figure 8. $\quad \delta^{18} \mathrm{O}, \delta^{13} \mathrm{C}$ and $\mathrm{Sr} / \mathrm{Ca}$ Measurements from Surprise Valley Tufa 33

Figure 9. $\quad$ Lake Surprise Lake Level Curve 37

Figure 10. Compilation of Regional Western North America Paleoclimate $\quad 41$

Figure 11. LGM Anomaly Maps for HadCM3 - Winds, Precipitation and 44

Figure 12. LGM Anomaly Maps for HadCM3 - Total Cloud Cover, 45

Evaporation, Precipitation Minus Soil Evaporation and Precipitation Minus Evapotranspiration

Figure A1. Map of Chewaucan Basin and Sample Collection Locations 49

Figure A2. $\quad{ }^{236} \mathrm{U}$ concentration calibration in StUTh1 52

Figure A3. $\quad{ }^{229}$ Th concentration calibration in StUTh1 54

\section{LIST OF TABLES}

Table 1. Average Identified Shoreline Elevations 23

Table 2. $\quad{ }^{230}$ Th-U Geochronology Measurements and Bulk Silicate Earth Detrital 27 Correction Ages

Table 3. Total Sample Dissolution Detrital Correction Activity Ratios and Ages 30

Table 4. Summary of $\delta^{18} \mathrm{O}$ and $\delta^{13} \mathrm{C}$ Analyses for Surprise Valley Tufa Samples 32

Table 5. Summary of Sr/Ca Analyses for Surprise Valley Tufa Samples 32

Table 6. Western North America Lake Stand Ages $\quad 38$

Table A1. Surprise Valley Watershed Climatic and Hydrologic Parameters 50

Table A2. Calibrated ${ }^{236}$ U Concentration in StUTh1 51

Table A3. Calibrated ${ }^{229}$ Th Concentration in StUTh1 53

Table A4. Column Chemistry Procedure for Separation of Th and U 54

Tables

A5-12. Elevation Transects Raw Data 


\section{INTRODUCTION}

Modern climate observations indicate that $\mathrm{CO}_{2}$-induced temperature increases are intensifying the global hydrologic cycle (Huntington, 2006; Barnett et al., 2008). Projecting into the $21^{\text {st }}$ century, increased anthropogenic greenhouse emissions, primarily $\mathrm{CO}_{2}$ from fossil fuel combustion, will cause changes in the seasonal and long-term availability of water, shifting the balance between precipitation and evapotranspiration (Seager et al., 2007). Changes in the spatial patterns and amount of rainfall caused by this hydrologic intensification in the climate system will also affect water resources (Meehl et al., 1999; Huntington, 2006), annual snow packs (Mote et al., 2004; Barnett et al., 2005), species migration (Walther et al., 2002), and may result in more extreme weather events such as flooding and drought (Meehl et al., 1999). Atmosphere-Ocean General Circulation Models (AOGCMs) are commonly used to model the effects of increased global temperatures, forced by increased anthropogenic $\mathrm{CO}_{2}$ emissions. However, among AOGCM simulations there is widespread disagreement regarding future shifts in hydrologic parameters, both in the direction of change (e.g. increased or decreased precipitation) and the magnitude of change (Seager et al., 2007; Solomon et al., 2007). At the same time, accurately predicting changes in groundwater and surface water availability for agricultural, urban and industrial uses will become increasingly important.

The predictive power of AOGCM models can be assessed using historical climate observations as baselines. Recent evaluations of an ensemble of AOGCMs using paleoclimatic data indicate that models appear to reproduce the directional changes in modeled parameters (e.g. rainfall and evaporation) and the large-scale climate patterns found in the geologic record, but appear to underestimate the magnitude of regional changes (Braconnot et al., 2012).

Reconstructing past changes in moisture availability during glacial-interglacial cycles places constraints on future changes in the hydrologic cycle in response to rising atmospheric $\mathrm{CO}_{2}$. The same AOGCMs used to predict future climate scenarios (Solomon et al., 2007) are also used to assess past climates (e.g. Braconnot et al., 2007; Laîné et al., 2009). The geologic record can be used to test the ability of AOGCMs to reproduce hydrologic and environmental responses to climatic forcings categorically different from those found within the modern or historical (late 1800s to present) climate record. Climate models simulating the Last Glacial Maximum (LGM, 19-26 ka) diverge in their prediction of past changes in rainfall amounts in the northeastern California/southern 
Oregon region, which is situated in the transition zone between a more arid Pacific Northwest and a wetter central and Nevada during the LGM (Kim et al., 2008; Laîné et al., 2009). Proxy-model intercomparison can indicate geographic regions of large uncertainty, test the magnitude and direction of climate parameters calculated in the models, and determine the response of the climate system to feedbacks on local and global scales (Booth et al., 2006; Braconnot et al., 2012). These feedbacks may include sea-land-ice sheet dynamics, vegetation changes, and surface albedo effects.

Ultimately, the ability to make confident predictions using AOGCMs for future warming scenarios will require geographically extensive paleoclimatic data to test the models' ability to predict past climate. Thus, producing paleoclimate records with welldated chronologies is important not just for our understanding of regional or global scale changes that occurred in the past, but also for future predictions of temperature, water availability, and seasonality. Paleoclimate data, such as those recorded in lake sediments and lake shorelines, can be used as a baseline for verification and interpretation of climate models (Booth et al., 2006). Paleoclimate data reconstructions are abundant in the oceans and at high latitudes in ice cores, but there are limited records from the continents at midlatitudes. Examples include $\delta^{18} \mathrm{O}$ and $\delta^{13} \mathrm{C}$ data from cave deposits (e.g. Oster et al., 2009; Wagner et al., 2010), basin analysis from lake sediment cores (e.g., Negrini et al., 2000; Cohen et al., 2000; Licciardi et al., 2001), dating of lake shoreline deposits (e.g. Oviatt et al., 1992; Garcia and Stokes, 2006), dating fluvial terraces (e.g. Sharp et al., 2003) and $\delta^{18} \mathrm{O}$ and $\delta^{13} \mathrm{C}$ data from soil carbonates (e.g. Amundson et al., 1996). This study seeks to fill gaps temporally and geographically in the paleoclimate record of the western United States. By constraining the timing and magnitude of fluctuations of the two lake systems in northeastern California (Surprise Valley) and southern Oregon (Chewaucan Basin), this study will increase the spatial coverage of paleoclimate data used to evaluate and test the different climate models in a region where they disagree. 


\section{BACKGROUND}

\subsection{Late Pleistocene Pluvial Lakes in Western North America}

Vast pluvial lakes occupying inward draining basins covered the landscape of western North America during the late Pleistocene (Figure 1). The presence of large lakes in the now-arid valleys of the Basin and Range during Pleistocene glacial periods points to a fundamentally different hydrologic balance, requiring either increased precipitation and/or decreased evaporation during the late Pleistocene glacial periods (Benson et al., 1990; Reheis, 1999a). Additionally, decreased temperature and increased relative humidity may have played a role in both increasing precipitation and/or decreasing evaporation. The net effect of the temperature changes is enhanced runoff within a given watershed, and diminished surface evaporation, leading to hydrologic conditions capable of creating and maintaining a lake system (Reheis, 1999a).

A lake's shoreline erosional features, along with the sedimentary facies, minerals and organic materials found in lake sediment cores, record the age of lake levels and the paleoenvironmental conditions (Adams and Wesnousky, 1998; Felton et al., 2006; Godsey et al., 2011). Therefore, the timing of fluctuations during past lake cycles can be determined by dating beach deposits such as tufa (Ku et al., 1998; Garnet et al., 2004) and studying lake sediment cores (e.g. Licciardi et al, 2000; Zic et al., 2002). Lake records provide spatially and temporally widespread paleoclimate data used to identify climatic processes driving precipitation patterns during the late Pleistocene. Small, closed basin pluvial lakes, such as those considered here, are perhaps most sensitive to changes in surface hydrology caused by increases in effective moisture (e.g. Licciardi, 2001; Garcia and Stokes, 2006). In the Great Basin, the chronology of lake highstands and later stillstands (e.g. periods of lake level equilibrium below the highstand) indicates a peak in moisture availability during and following the Last Glacial Maximum (LGM, 19-26ka) (Tchakerian and Lancaster, 2002) and also records the subsequent transition to more arid conditions during the Pleistocene to Holocene deglaciation. However, the atmospheric and hydrologic mechanisms explaining the late, post LGM lake highstands is still an outstanding research question in the paleoclimatology of western North America.

Paleoshoreline age records in pluvial lake basins also enhance ongoing research in the fields of paleohydrology, paleoenvironment and neotectonics. Distinct, constructional shorelines are excellent recorders of lake-level fluctuations because they are rapidly formed by wave action (Scholfield et al., 2004; Felton et al., 2006; Jewell, 2007; Jewell 
and Nicoll, 2011). Shoreline age data constrain short-term changes in the hydrologic balance of a particular lake system. Additionally, as horizontal geomorphic features, shorelines are paleohorizontal datums that have been used to measure both brittle faulting and broad unwarping of the lithosphere (Bills and May, 1987; Adams and Wesnousky, 1998; Oldow and Singleton, 2008). However, due to subsequent erosion, isostatic rebound and eolian inputs, natural variability is often observed in shoreline deposits (Scholfield et al., 2004; Jewell, 2007; Jewell and Nicoll, 2011) and it is important to recognize these processes when interpreting elevation data. Past studies have used a variety of techniques to quantify a lake's past hydrologic budget, climatic history and paleoenvironment. Interpreting results from geomorphic mapping, geophysical methods (such as terrestrial LiDAR on shoreline features), geochemistry (stable isotope analysis and elemental analysis of sediments or shoreline deposits), and geochronology (U-series, ${ }^{14} \mathrm{C}$ dating and/or cosmogenic nuclides) enable the geologic history of a lake system to be unraveled. 


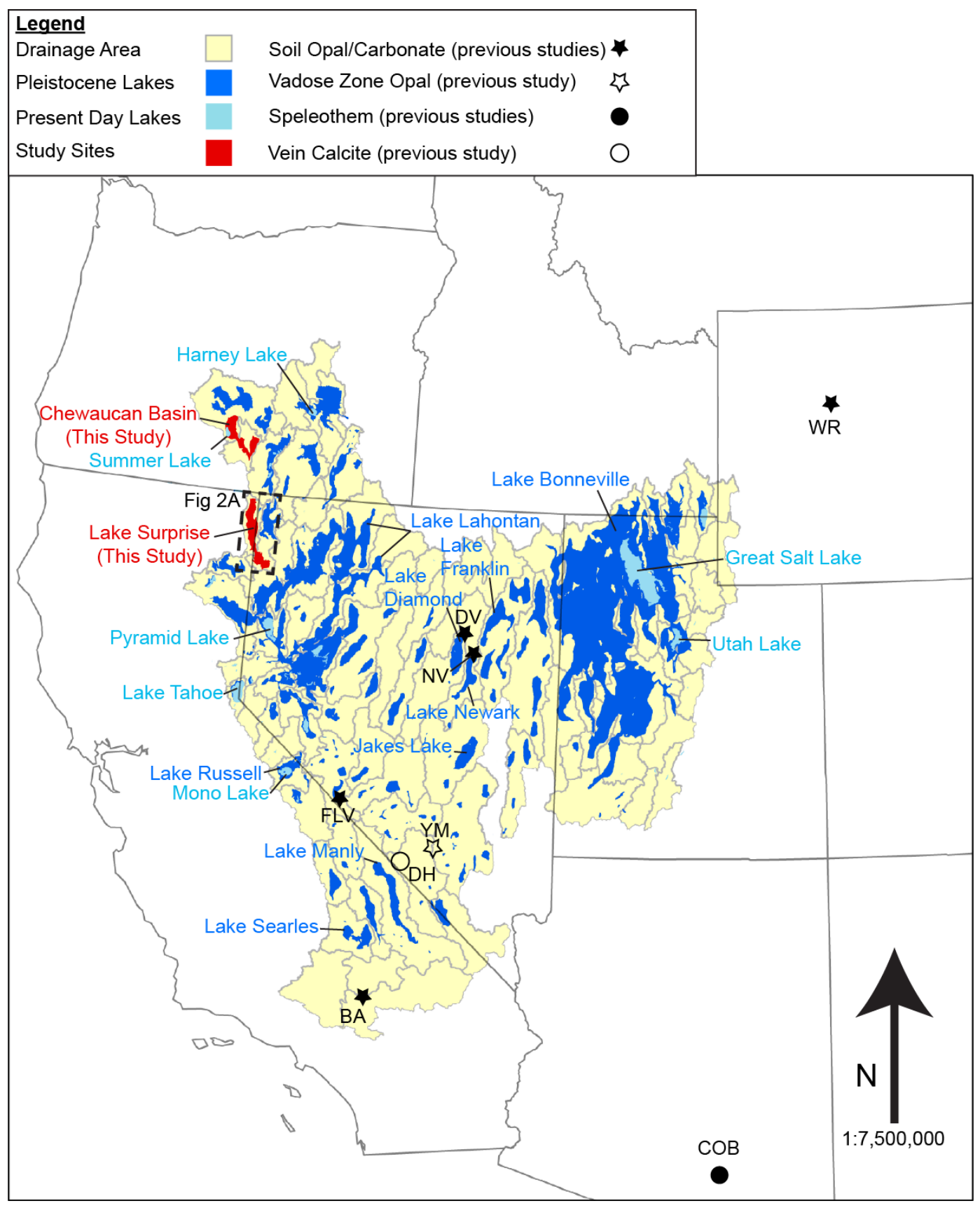

Figure 1. Map of the Western United States with Late Pleistocene Pluvial Lakes and Additional Paleoclimate Records (adapted from Reheis, 1999b). The yellow outline is the EPA defined Basin and Range province based on watershed regions. The dark blue areas indicate basins filled with lake systems during the late Pleistocene and light blue are modern lakes. The red areas are Lake Surprise and the Chewaucan Basin lake systems (this study). The additional paleoclimate records, used for comparison are found denoted by the black stars and circles. Data from previous studies includes a $\Delta$ P-ET proxy using $\left({ }^{234} \mathrm{U} /{ }^{238} \mathrm{U}\right)_{0}$ for pedogenic carbonates from Wind River, Wyoming (WR) (Sharp et al., 2003), deep vadose zone opal from Yucca Mountain (YM) (Paces et al., 2010) and pedogenic opal from Diamond Valley, Nevada (DV), Newark Valley, Nevada (NV), Fish Lake Valley, Nevada (FLV) and Barstow, California (BA) (Maher et al., in prep); vein calcite from Devils Hole, Nevada (DH) (Winograd et al., 2006); speleothem from Cave of the Bells, Arizona (COB) (Wagner et al., 2010); and the timing of lake highstands at Lake Bonneville, Utah (Oviatt et al., 1992); Lake Lahontan, Nevada (Adams and Wesnousky, 1998); Lake Newark, Nevada (Kurth et al., 2011); Lake Diamond, Nevada (Tackman, 1993); Lake Jakes Lake, Nevada (Garcia and Stokes, 2006); Lake Manly, California (Ku et al., 1998) and Searles Lake, California (Lin et al., 1998). 


\subsection{Geologic and Climatic Setting}

Extensional faulting in the Basin and Range province in the western United States formed numerous N-S-trending basins throughout the region. Most are closed basins (also referred to as terminal or endorheic basins), such that the basin retains all precipitation and allows no outflows of water to adjacent basins. Many of these closed basins sustained pluvial lakes during glacial periods of the Pleistocene but have since diminished in size or developed playa lakes during the Holocene (Figure 1) (Reheis, 1999a; Orme, 2008). Playas contain shallow lakes seasonally (during winter months) or during prolonged wet spells such as El Nino years (Orme, 2008).

In the late Pleistocene, highstands in these closed basins appear to postdate the LGM (Garcia and Stokes, 2006). However, changes in lake water levels are not necessarily synchronous between adjacent or nearby basins. These variations may be due to changes in the storm tracks that deliver moisture, basin-to-basin variability in water storage capacity, the surface area available to evaporation relative to lake volume, and linkages to adjacent basins (Orme, 2008). Lake level fluctuations in many systems (e.g. Bonneville, Lahonton, Russell, and Searles shown in Figure 1) have been attributed to the position of the mean winter westerly storm tracks (or jet stream) that bring winter precipitation to the region (Benson et al., 1990; Benson et al., 1998). The latest Pleistocene lake highstand and geochemical variations in the Chewaucan Basin have also been explained by changes in the position of the mean westerly storm tracks (Licciardi, 2001; Negrini, 2002; Zic et al., 2002), but this record has not been compared to other basins. Other research on smaller closed basins, such as Lake Franklin, NV (Figure 1), has concluded that local lake/atmosphere feedback processes, including parameters such as increased cloud albedo, increased relative humidity and lowered net evaporation, better explain the presence of lake systems during glacial periods of the late Pleistocene (Garcia and Stokes, 2006).

Surprise Valley, CA, and the Chewaucan Basin, OR, on the western edge of the Basin and Range (Figure 1) capture precipitation brought by the westerly storm systems. Both basins are geographically positioned closer to the Pacific Ocean relative to other lake records from the Basin and Range. Thus, changes in lake levels should be more directly linked to changes in the intensity and geographic position of westerly storm tracks. The following is a summary of the geologic and climatic setting for the main study site, Surprise Valley, CA, and the Chewaucan Basin, OR. 


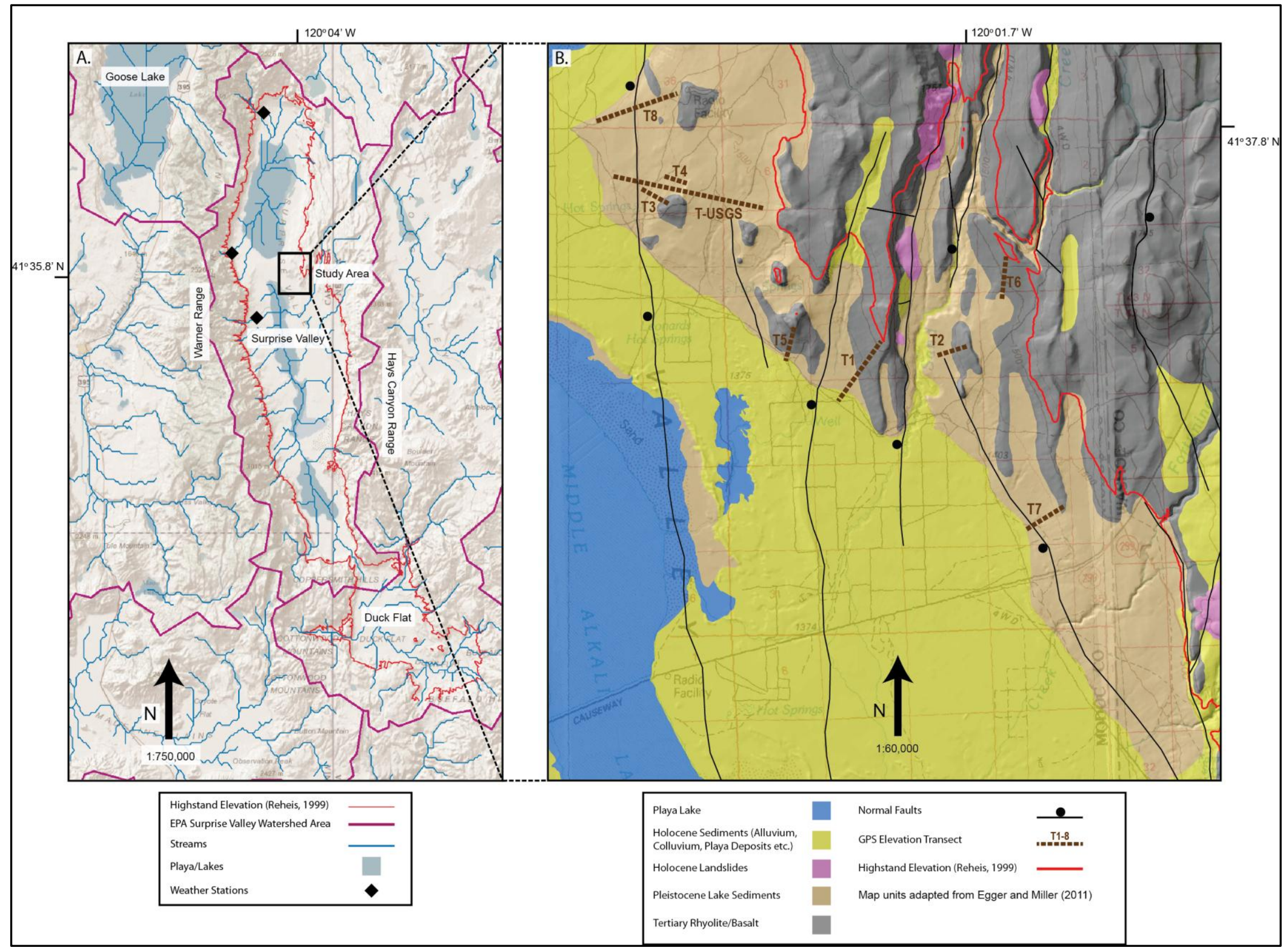


Figure 2. Maps of the Surprise Valley Watershed and the Primary Study Area (Previous Page). (A) Shaded relief map of Surprise Valley (1:750:000) with the Environmental Protection Agency (EPA) Surprise Valley watershed outlined in magenta. The highstand elevation estimated by Reheis (1999b) is denoted by the red outline. The location of the three weather stations used in this study (data summarized in Figure. 3) is denoted by black diamonds. (B) Simplified

geological map of the study area (1:60,000), with a Digital Elevation Model (DEM) and USGS 100k topography map used as a baselayer, adapted from Egger and Miller (2011) ArcGIS database and field observations, with observed and inferred faults (black lines), the Reheis (1999b) highstand elevation (magenta lines) and GPS elevation transects (brown lines, numbered T1-8 for the handheld GSP transects and

T-USGS for the continuous transect obtained from Dr. Jonathan Glen). EPA's watershed regions are a publicly available dataset

(http://cfpub.epa.gov/surf/huc.cfm?huc code=18080001) and the stream data are based on high-resolution elevation data obtained from NASA's Shuttle Radar Topography Mission and made publicly available by the USGS HydroSHEDS program (http://hydrosheds.cr.usgs.gov/). 


\subsubsection{Surprise Valley, California}

Surprise Valley $\left(41.53^{\circ} \mathrm{N}, 120.17^{\circ} \mathrm{W}\right)$, in northeast California, sits on the northwest margin of the Basin and Range province (Figures 1 and 2). The N-S trending valley is a high altitude desert with three seasonal playa lakes. Surprise Valley is bounded on the west by the Surprise Valley fault, but the eastern margin is more complex, and the valley transitions from a full-graben in the south to a half-graben in the north (Personius et al., 2008; Egger et al., 2009; Lerch et al., 2009; Egger and Miller, 2011). The accommodation zone between the half-graben in the north upper lake basin and the full graben in the middle and lower lake basins contains the most lake-related features, such as terraces and visible shorelines sets.

The modern watershed area demarcation by the Environmental Protection Agency (EPA) and USGS HydroSHEDS stream analysis demonstrate that Surprise Valley is a closed, terminal basin (Figure 2A). As a terminal basin, the establishment of a seasonal, decadal or millennial lake at Surprise Valley should be directly correlated to precipitation falling within the area of the watershed. The highstand elevation reported by Reheis (1999b) along with the modern topography suggests that minimal overflow occurred at the highstand to the south into Duck Flat. Thus, Duck Flat is considered part of the lake system.

It was recognized by early geologists that the highstand shoreline and sets of lower elevation shorelines appeared laterally continuous through the valley and into Duck Flat. The presence of an ancient lake system in Surprise Valley was first postulated by I.C. Russell (1884), and was first surveyed and described extensively by R.J. Russell (1927). Previous mapping and GPS transect work by Zimbelman et al. (2009), Sack (2002), Elder and de la Fuente (2009) and Reheis (1999b) suggests that the high stand, and thus the receding shorelines of Lake Surprise are similar to late Pleistocene $(<100 \mathrm{ka})$ lakes commonly seen in other valleys in the Basin and Range province. Zimbelman et al. (2009) measured the high stand shoreline in the south part of the valley at 1533.6 meters whereas Reheis (1999b) reports 1567 meters (Figure 2A). Because Surprise Valley is thought to have been a closed basin with no overflow (Sack, 2002), highstand shorelines likely correspond to glacial periods as previously found in other Basin and Range terminal basins. Preliminary work by Elder and Juan de Fuqa (2009) suggests that the highstand is Marine Isotope Stage (MIS) 2 ( $17 \mathrm{ka})$ based on dating of landslide deposits that were cut and reworked by Pleistocene Lake Surprise in the north end of the valley. 
The primary purpose of this study was to date both the highstand shoreline and lower stillstand shorelines using ${ }^{230} \mathrm{Th}-\mathrm{U}$ geochronology of lake tufas found at the shoreline surfaces on the exposed bedrock.

The meteorological data shown in Figure 3 demonstrates why a modern lake does not persist year-round in Surprise Valley. Precipitation and relative humidity roughly covary, with increased humidity and precipitation occurring during the winter months. Predictably, temperature and evapotranspiration also covary, with increased temperatures and increased evapotranspiration occurring during the summer months. The net difference between precipitation and evapotranspiration (P-ET) of the historical meteorological data sets (see references in Figure 3 caption) indicate an average net loss of water from the basin of $-6.96 \mathrm{~cm} /$ month, with a yearly P-ET of $-0.83 \mathrm{~cm}$. During a typical year, playa lakes form during the wetter, colder winter season in all three subbasins (upper, middle, and lower) of Surprise Valley. During December to February, PET is positive, averaging $6.03 \mathrm{~cm} /$ month. Seasonal swings in the relative humidity in the historical meteorological data show an average relative humidity of $72.43 \%$ during the winter months, whereas during summer months relative humidity averages $42.80 \%$. A summary of the hydrologic and climatic data for the Surprise Valley watershed can be found in the Appendix, Table A1. 

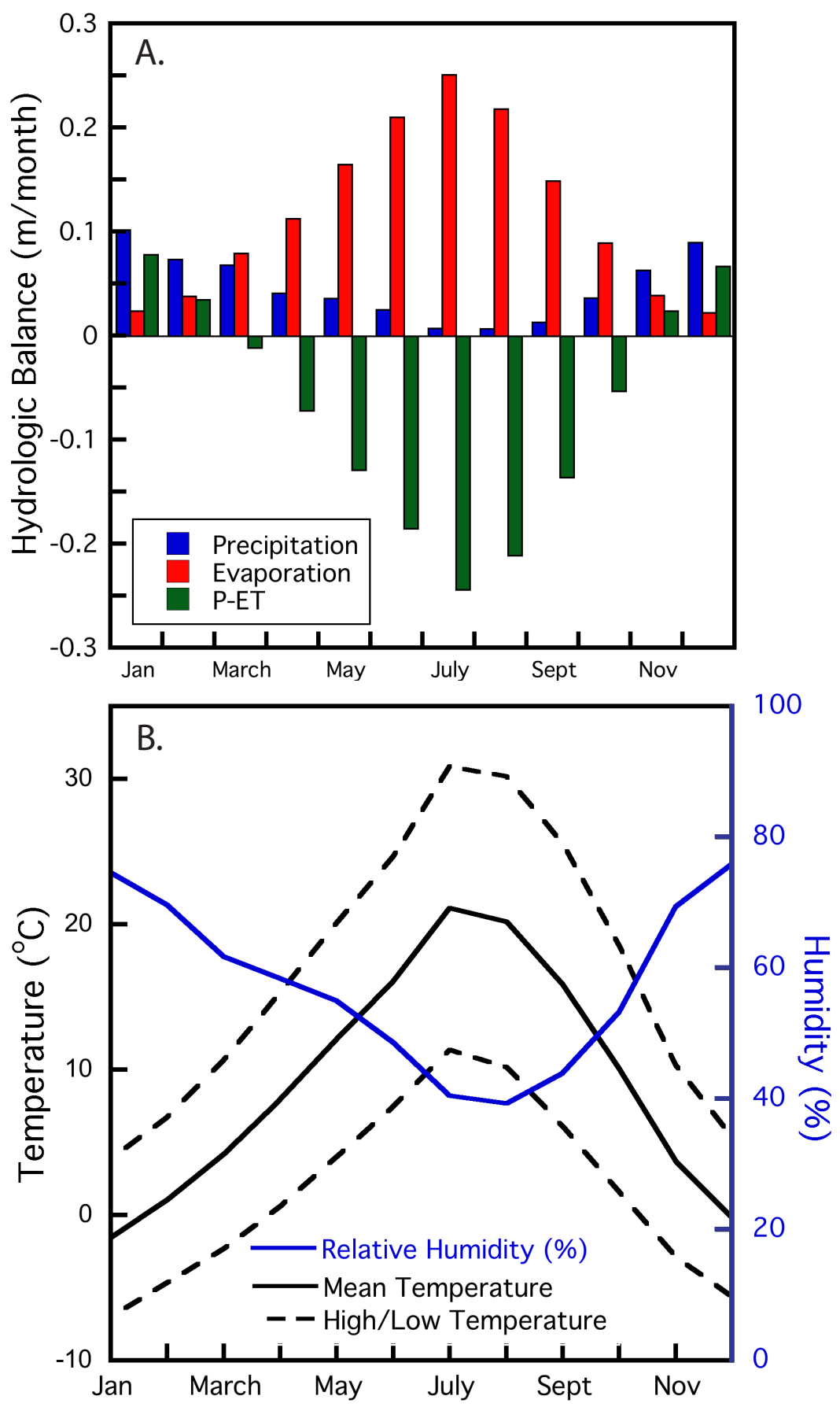

Figure 3. Historical Hydrologic and Climate Data for the Surprise Valley Watershed. (A)

Precipitation, evapotranspiration and calculated precipitation minus evapotranspiration (P-ET). Units are all $\mathrm{m} /$ month. (B) Mean, high and low temperature $\left({ }^{\circ} \mathrm{C}\right)$, and relative humidity $(\%)$. The precipitation and temperature data is a composite average from three historical datasets maintained by the Western Regional Climate Center (WRCC, http://www.wrcc.dri.edu/) spanning 1894-2012 from the Cedarville, Lake City and Fort Bidwell, CA weather stations (all sites within Surprise Valley, see Figure 2B). Both temperature and precipitation are directly measured with precipitation being both rain and snow amounts, adjusted for liquid water amounts. The evaporation and relative humidity data was obtained from the Pacific Northwest Cooperative Agricultural Weather Network database (AgriMet, http://www.usbr.gov/pn/agrimet/index.html) for Cedarville, CA; the database spans the period 1985-2011. Relative humidity is directly measured and evaporation data is computed using the Kimberly Penman procedure (Dockter, 1994) using other climate variables such as wind speed, surface water availability, and temperature. 


\subsubsection{Lake Chewaucan Basin, Oregon}

Summer Lake $\left(42.69^{\circ} \mathrm{N}, 120.55^{\circ} \mathrm{W}\right)$, in south-central Oregon, sits within the greater ancient Lake Chewaucan basin, a large pluvial lake system, with a proposed highstand at 13ka (Licciardi, 2001; Negrini, 2002). At its peak, Lake Chewaucan covered $1244 \mathrm{~km}^{2}$, was $114 \mathrm{~m}$ deep and filled four sub-basins (Liccardi, 2001). Summer Lake sits in the northwest end of the sub-basins and is connected to the Upper Chewaucan Marsh by an overflow channel in its southeastern corner. Further southeast the Chewaucan Basin encompasses Lake Abert and the Lower Chewaucan Marsh as well (see Figure 1 and Appendices, Figure 1A). The Chewaucan Basin has been the subject of numerous studies of past lake history (e.g. Cohen et al., 2000; Negrini et al., 2000; Licciardi, 2001; Zic et al., 2002). Researchers have taken advantage of the extensive tephra layers, well-preserved sediments and fossils. In particular, Licciardi (2001) constrained the timing of the lake-surface fluctuations during the latest Pleistocene lake cycle. I will compare my ages from ${ }^{230} \mathrm{Th}-\mathrm{U}$ geochronology to the ${ }^{14} \mathrm{C}$ dated lake level record produced by Licciardi (2001).

\section{$2.3{ }^{230}$ Th-U Geochronology}

Relative ages of surfaces have successfully been applied to Basin and Range shorelines and alluvial fans by using a combination of soil-profile development, tephra chronology, radiocarbon chronology, geomorphic position, and the extent of $\mathrm{CaCO}_{3}$ accumulation (eg. Harden et al., 1991; Tackman, 1993; Redwine, 2003). However, the optimum age dating technique will provide numerical ages. Absolute age-dating techniques include radiocarbon geochronology, ${ }^{230} \mathrm{Th}-\mathrm{U}$ geochronology and the use of cosmogenic isotopes (such as ${ }^{36} \mathrm{Cl},{ }^{10} \mathrm{Be},{ }^{26} \mathrm{Al},{ }^{3} \mathrm{He}$ ) (Benson, 2003). This study used ${ }^{230} \mathrm{Th}-\mathrm{U}$ geochronology of tufas to provide absolute ages of surfaces.

Uranium, a radioactive element, consisting of $99.28 \%{ }^{238} \mathrm{U}\left(\mathrm{t}_{1 / 2}=4.46 \mathrm{Gyr}\right)$, decays via the following sequence: ${ }^{238} \mathrm{U} \rightarrow{ }^{234} \mathrm{Th} \rightarrow{ }^{234} \mathrm{~Pa} \rightarrow{ }^{234} \mathrm{U} \rightarrow{ }^{230} \mathrm{Th}$. The ${ }^{234} \mathrm{Th}$ and ${ }^{234} \mathrm{~Pa}$ daughter isotopes are short-lived compared to ${ }^{238} \mathrm{U},{ }^{234} \mathrm{U}$ and ${ }^{230} \mathrm{Th}$. Samples can be dated using the activity ratios of the two long-lived daughter isotopes $\left({ }^{234} \mathrm{U} /{ }^{238} \mathrm{U}\right)$ and $\left({ }^{230} \mathrm{Th} /{ }^{238} \mathrm{U}\right)$, where parentheses denote activity ratios. Due to the relatively short halflives of ${ }^{230} \mathrm{Th}\left(\mathrm{t}_{1 / 2}=75.4 \mathrm{kyr}\right)$ and ${ }^{234} \mathrm{U}\left(\mathrm{t}_{1 / 2}=245 \mathrm{kyr}\right){ }^{230} \mathrm{Th}-\mathrm{U}$ geochronology has an 
upper age limit of about $500 \mathrm{ka}$. The equation for calculating the ingrowth of ${ }^{230} \mathrm{Th}$ is (Kaufman and Broecker, 1965):

$\frac{{ }^{230} \mathrm{Th}}{{ }^{234} \mathrm{U}}=\frac{1+\mathrm{e}^{-\lambda_{0} t}}{{ }^{234} \mathrm{U} \backslash{ }^{238} \mathrm{U}}+\left(1-\frac{1}{{ }^{234} \mathrm{U} \backslash{ }^{238} \mathrm{U}}\right)\left(1-\frac{\lambda_{0}}{\lambda_{0}-\lambda_{4}}\right)\left[1-e^{-\left(\lambda_{0}-\lambda_{4) t}\right.}\right]$

where $\lambda_{0}$ and $\lambda_{4}$ are decay constants for ${ }^{230} \mathrm{Th}$ and ${ }^{234} \mathrm{U}$, respectively, $t$ is the time since the mineral formed and $\mathrm{Th}$ and $\mathrm{U}$ are the concentrations of the given Th or $\mathrm{U}$ isotope. Under oxidizing conditions typical of surface waters, $\mathrm{U}$ is mobile as the hexavalent uranlyl ion $\left(\mathrm{U}(\mathrm{VI}) \mathrm{O}_{2}{ }^{2+)}\right.$ and is readily incorporated into secondary minerals such as carbonates $(\mathrm{Ku}$, 2000; Reeder et al., 2001). In contrast, Th is relatively insoluble under oxic conditions, and ideal samples have low initial Th concentrations such that all ${ }^{230} \mathrm{Th}$ is derived from radioactive decay of ${ }^{234} \mathrm{U}$ in the sample. However, by measuring the abundance of ${ }^{232} \mathrm{Th}$ in the sample, corrections can be made for any "detrital Th" (e.g. Th derived from other processes aside from purely radioactive decay) that may have originally been incorporated into the mineral (Edwards et al., 1987; Ludwig and Titterington, 1994; Neymark and Paces, 2000; Sharp et al., 2003; Paces et al., 2004; Maher et al., 2007; Fletch et al., 2010). 


\section{METHODS}

\subsection{Field Methods}

\subsubsection{Elevation Transects}

Elevation transects were obtained with GPS measurements up gently sloping hills formed primarily on basalt dip slopes and rhyolite plugs (see Figure 2 for location of study area and transects). This location, in the middle of Surprise Valley, has extensive, laterally continuous shoreline features that can be correlated among different hillslopes (Figure 4B). Lake levels were characterized by identifying the edge of horizontal terraces below a crest or rise in topography. Figure 4B and 4C show horizontal terraces, assumed to indicate the erosion of bedrock via wave action at different lake water levels. Eight transects were carried out (for locations see Figure 2B) using a handheld Garmin Oregon 550t GPS unit to measure the distance from origin and elevation of each identified shoreline feature. In addition to the handheld GPS measurements, one very accurate continuous transect was obtained from USGS scientist Jonathan Glen. This transect, originally walked to measure near surface magnetic anomalies simultaneously with GPS co-ordinates, captured the shoreline set from near valley bottom at $1402 \mathrm{~m}$ to $1470 \mathrm{~m}$ in the vicinity of transects 3, 4 and 8 (see Figure $2 \mathrm{~B}$ for location). 


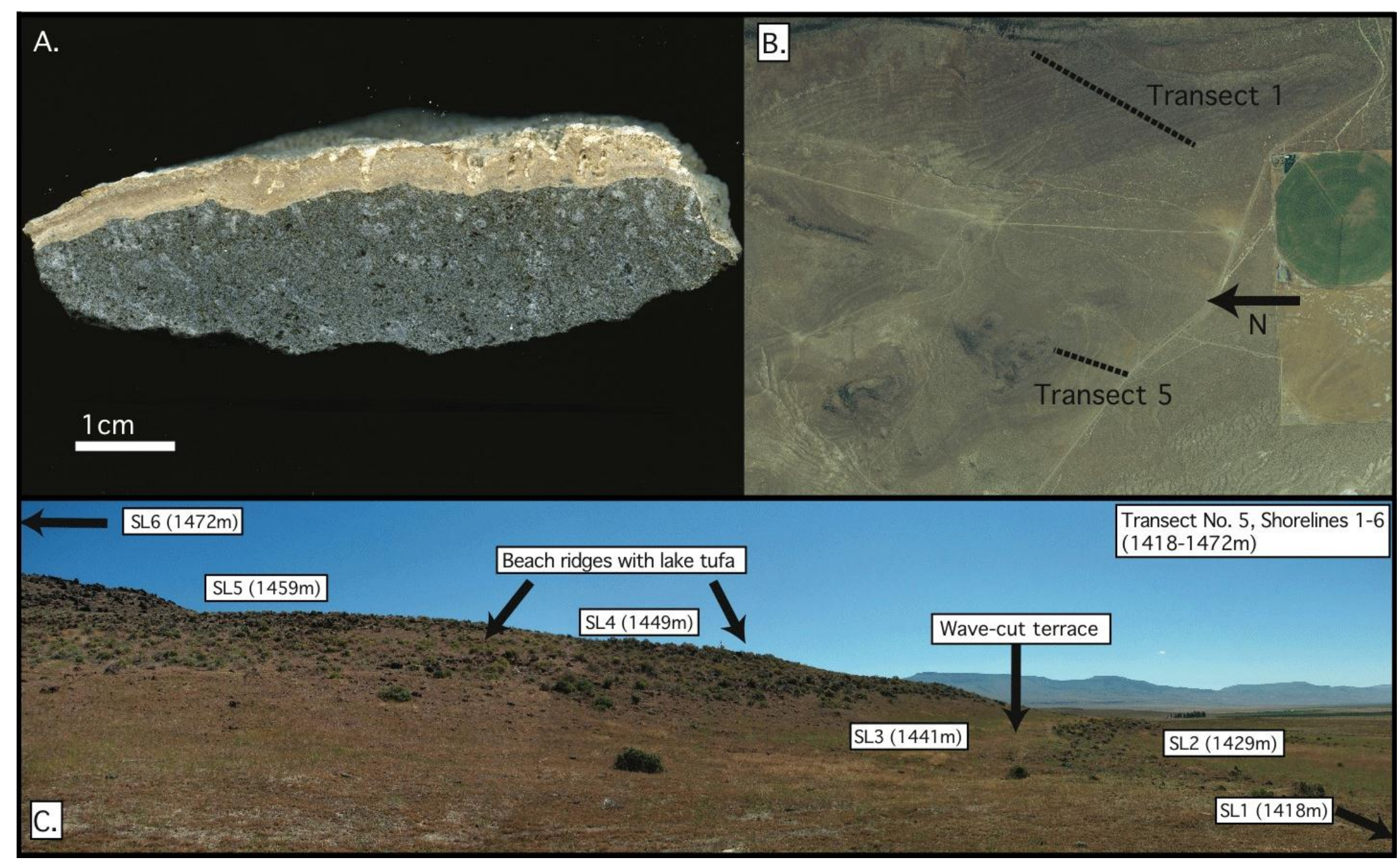

Figure 4. Tufa Sample and Field Images. (A) Scanned cut cross section of example tufa sample collected in situ on basalt bedrock. This is sample SVT18-1, elevation $1552 \mathrm{~m}$ just below the highstand elevation of $1565.5 \mathrm{~m}$. (B) Cropped Digital Orthophoto Quadrangles imagery derived from aerial photos. Laterally continuous shoreline features (terraces and beach ridges) are visible among multiple dip slopes. The location of transects 1 and 5 are denoted by the dashed line. (C) Side view of transect no. 5 standing on shoreline no. 3. Lake levels were characterized by identifying the edge of horizontal wave-cut terraces below a rise in topography associated with beach ridges. 


\subsubsection{Sample Collection}

Tufa samples were collected in situ from exposed bedrock on the front edge or crest of the wave-cut terraces and are assumed to correspond to lake levels at that terrace elevation. Eighteen tufa samples were collected in Surprise Valley in the same area as the elevations transects (Figure 2B). All samples were laminar and encrusted on exposed bedrock (Figure 4A). Tufa is not present at all shoreline elevations, and varies in thickness $(0.1-5 \mathrm{~cm})$ and abundance. Six of eleven shorelines included tufa clasts on the slopes along transects 1, 2 and 5, and all of these were sampled. ${ }^{230} \mathrm{Th}-\mathrm{U}$ geochronology is optimal for lake tufas, such as those found on the exposed bedrock below the wavecut surfaces at Surprise Valley, CA. ${ }^{230}$ Th-U geochronology can also be applied to soil carbonates from the soils developed on surfaces (e.g. Sharp et al., 2003), such as the horizontal shoreline surfaces of shoreline sets found at Summer Lake, OR (Figure 4C).

Hydrothermal carbonate deposits can be found around Surprise Valley corresponding to modern and extinct hot springs (Egger and Miller, 2011), but these were avoided. Sampling of lacustrine tufa was not carried out in the vicinity of these hydrothermal deposits to avoid potential sampling tufa that may have been diagentically altered.

Additionally, three tufa samples (from elevations of 1333, 1326, and 1319 meters) were collected from the Chewaucan Basin, at the north end of modern Summer Lake (See Figure A1 in Appendices for sampling locations). 


\subsection{Laboratory Methods}

The following is a summary of the laboratory work carried out on the tufa samples. This included the application of ${ }^{230} \mathrm{Th}-\mathrm{U}$ geochronology (column chemistry and isotopic analysis), stable isotopic analyses and elemental analyses. In addition, a thorough calibration of a new ${ }^{229} \mathrm{Th} /{ }^{236} \mathrm{U}$ spike (StUTh1), used for ${ }^{230} \mathrm{Th}-\mathrm{U}$ geochronology, was carried out before the analysis of samples.

\subsection{1 ${ }^{230}$ Th-U Geochronology}

The primary purpose of this study was to date the tufa collected from both basins using the absolute dating technique of ${ }^{230} \mathrm{Th}-\mathrm{U}$ geochronology. I processed 21 samples and two aliquots of secular equilibrium opal standard (BZVV from Virgin Valley, NV obtained from the Royal Ontario Museum) using the following methods to accurately determine the $\mathrm{Th}$ and $\mathrm{U}$ isotopic ratios of the samples. Following this, the two detrital correction calculation methods (TSD and BSE) were applied to the measured isotope ratios of each set of samples.

\subsubsection{Spike Calibration}

In order to accurately measure the $U$ and Th concentrations of carbonates low in $\mathrm{U}$ and Th, such as the tufas from Surprise Valley and the Chewaucan Basin, a new isotopic spike optimized for measurement by multi-collector inductively coupled plasma mass spectrometer (MC-ICP-MS) was calibrated. Mixed spikes used in ${ }^{230} \mathrm{Th}-\mathrm{U}$ geochronology use isotopes of Th and $U\left({ }^{229} \mathrm{Th}\right.$ and $\left.{ }^{236} \mathrm{U}\right)$ not found naturally. ${ }^{236} \mathrm{U}$ and ${ }^{229} \mathrm{Th}$ are both long-lived byproduct isotopes collected during nuclear reactor energy production and from spent nuclear fuel.

Several parameters had to be evaluated in order to dilute the existing spike to the appropriate concentrations of ${ }^{229} \mathrm{Th}$ and ${ }^{236} \mathrm{U}$ for carbonate rocks. The analytical and laboratory constraints that had to be considered were: (1) the average concentration of $U$ and Th in both young and secular equilibrium carbonate samples likely to be analyzed at the Stanford ICP-MS/TIMS facility; (2) the sensitivity and limits of accuracy on measurements made using the Faraday detectors and ion counters on the $\mathrm{Nu}$ Plasma High Resolution MC-ICP-MS; (3) the optimal spike to sample ratio of ${ }^{229} \mathrm{Th} /{ }^{230} \mathrm{Th}$; and (4) the amount of spike per sample that can be most precisely measured gravimetrically (found 
to be $10-100 \mu \mathrm{L})$. All of these constraints were accounted for when making StUTh1, the mixed spike used in this study.

Following dilution of the spike, the concentrations of ${ }^{236} \mathrm{U}$ and ${ }^{229} \mathrm{Th}$ were determined by using certified gravimetric standards for ${ }^{238} \mathrm{U}$ and ${ }^{232} \mathrm{Th}$ (U standard was CRM 145 from the New Brunswick Laboratory of the US Department of Energy and Th standard was Ames Th Metal from the Ames Laboratory of the US Department of Energy). Neither gravimetric standard has ${ }^{236} \mathrm{U}$ or ${ }^{229} \mathrm{Th}$.

The final ${ }^{236} \mathrm{U}$ concentration, analyzed over the period of sample analysis, based on an error weighted average of the data (see Appendices, Table A2, Table A3, Figure A2 and Figure A3) was found to be $0.91987 \pm 63 \mathrm{ng} / \mathrm{g}(2 \sigma, \mathrm{MSWD}=0.60, \mathrm{n}=18)$, and the ${ }^{229}$ Th concentration was found to be $0.22418 \pm 58 \mathrm{ng} / \mathrm{g}(2 \sigma, \mathrm{MSWD}=0.89, \mathrm{n}=32)$. All error propagation used two sigma percent errors and the errors on the concentration measurements were calculated as the square root of the sum of the analytical and gravimetric errors squared.

\subsubsection{Sample Dissolution}

Tufa samples were cut using a microsaw into 0.5-3 gram chips. Thick laminar samples were targeted to avoid areas of high porosity or possible re-crystallization. To remove dust and clean the tufa, 1-3 gram of sample was rinsed in ethanol and dried.

The clean samples, selected under an optical microscope, were combined with the calibrated mixed spike of ${ }^{236} \mathrm{U}$ and ${ }^{229} \mathrm{Th}$, and then dissolved in $14 \mathrm{~N}$ nitric acid $\left(\mathrm{HNO}_{3}\right)$ and treated with hydrogen peroxide $\left(\mathrm{H}_{2} \mathrm{O}_{2}\right)$ to remove detrital organic material. Some samples did not fully dissolve and contained an insoluble fraction. The insoluble fraction was dissolved using aqua regia $\left(\mathrm{HNO}_{3}-\mathrm{HCl}\right)$, followed by a hydrofluoric acid ( $\left.\mathrm{HF}\right)$ digestion. In preparation for chemical purification samples were brought up in $4 \mathrm{~mL}$ of 1.5 $\mathrm{N} \mathrm{HNO}_{3}$. Two complete procedural blanks were prepared in tandem with sample dissolution.

\subsubsection{Column Chemistry}

The dissolved tufa samples were purified by ion exchange chromatography using Eichrom TRU-spec resin in $0.2 \mathrm{~mL}$ Teflon columns following the procedure of Luo et al., (1997). The column chemistry recipe is outlined in the Appendices, Table A2. An additional step of $0.6 \mathrm{M} \mathrm{HF}$ was included at the end of $U$ collection to ensure maximum $U$ 
collection. For samples with known concentration and the two aliquots of BZVV, the yield of the column chemistry was found to be $\sim 85 \%$ for $U$ and $\sim 75 \%$ for Th. Along with each set of samples, four in total, a column blank was put through the same chemistry as all samples.

\subsubsection{Isotopic Analyses}

The $\mathrm{U}$ and Th column fractions were evaporated to dryness and re-dissolved in $2 \% \mathrm{HNO}_{3}$ and $2 \% \mathrm{HNO}_{3}+$ trace $\mathrm{HF}$, respectively. I analyzed the $\mathrm{U}$ and Th isotopic compositions within the ICP-MS/TIMS Facility at Stanford University, using a Nu Instruments Plasma HR multi-collector inductively coupled plasma mass spectrometer (MC-ICP-MS) equipped with 12 Faradays and 4 discrete dynode secondary electron multipliers (SEM). One of the ion counters (IC0) has an additional decelerating lens filter to improve abundance sensitivity. Measurements were made in dry plasma mode using an Aridus II desolvating nebulizer. All $\mathrm{U}$ and Th isotopic standards and solutions were also diluted in $2 \% \mathrm{HNO}_{3}$ and $2 \% \mathrm{HNO}_{3}+$ trace $\mathrm{HF}$, respectively. Concentrations between samples and standards were matched as closely as possible and washout between measurements was monitored until signals on all detectors returned to background levels. $\mathrm{U}$ isotopes were measured in static mode with ${ }^{236} \mathrm{U}$ and ${ }^{234} \mathrm{U}$ measured simultaneously in the ion counters IC 0 and IC1, and ${ }^{235} \mathrm{U}$ and ${ }^{238} \mathrm{U}$ were measured on Faraday cups. The measured ${ }^{235} \mathrm{U} /{ }^{238} \mathrm{U}$ ratio was used to correct for instrumental mass fractionation based on an exponential law, and bracketing standards of CRM U010 were used to correct the ${ }^{234} \mathrm{U} /{ }^{238} \mathrm{U}$ and ${ }^{236} \mathrm{U} /{ }^{238} \mathrm{U}$ ratios for Faraday/IC gain. A certified isotopic standard, CRM 145 (also known as CRM-112) was analyzed repeatedly during the analytical sessions to assess reproducibility. During the time period of the analyses and spike calibration the measured ${ }^{234} \mathrm{U} /{ }^{238} \mathrm{U}$ was $0.000052613 \pm 41(2 \sigma, \mathrm{n}=37)$ for CRM 145 . The certified ${ }^{234} \mathrm{U} /{ }^{238} \mathrm{U}$ of CRM 145 is $0.000052841 \pm 79(2 \sigma)$.

Th isotopes were measured dynamically with ${ }^{229} \mathrm{Th}$ and ${ }^{230} \mathrm{Th}$ in IC0 and ${ }^{232} \mathrm{Th}$ in Faraday cups. Bracketing standards of IRMM-035 were used to correct samples for instrumental mass fractionation and Faraday/IC gain. The tail contribution from ${ }^{232} \mathrm{Th}$ onto ${ }^{230}$ Th was monitored by concurrently measuring the signal at 0.5 and 0.4 amu on the high mass side of the ${ }^{230} \mathrm{Th}$ peak center and $0.5 \mathrm{amu}$ on the low mass side of the ${ }^{230} \mathrm{Th}$ peak. By statically measuring the tail across the mass spectrum from 229.5 to $230.5 \mathrm{amu}$

we found that a logarithmic correction provided the best model for the tailing of ${ }^{232} \mathrm{Th}$ 
onto ${ }^{230}$ Th (cf. Hoffmann et al., 2007; Sims et al., 2008) and thus a logarithmic tail correction was used to correct standards and samples for the tail contribution at ${ }^{230} \mathrm{Th}$. The abundance sensitivity at 2 amu was less than $80 \mathrm{ppb}$ for most analyses resulting in a small correction for tailing of ${ }^{232} \mathrm{Th}$ onto ${ }^{230} \mathrm{Th}$. Typically, the correction was between $0.5 \%$ and $1.5 \%$ of the ${ }^{230} \mathrm{Th}$ signal. The ${ }^{229} \mathrm{Th} /{ }^{230} \mathrm{Th}$ ratio was not corrected for mass fractionation, which is expected to be small over this mass range. Th Ames Metal was analyzed repeatedly during the analytical sessions to assess reproducibility. During the time period of the sample analyses and spike calibration the measured ${ }^{230} \mathrm{Th} /{ }^{232} \mathrm{Th}$ for $\mathrm{Th}$ Ames Metal was $0.00005744 \pm 44(\mathrm{n}=34)$.

The isotopic measurements of secular equilibrium opal standard, BZVV, gave average activity ratios of $\left({ }^{234} \mathrm{U} /{ }^{238} \mathrm{U}\right)=1.000 \pm 0.003$ and $\left({ }^{230} \mathrm{Th} /{ }^{238} \mathrm{U}\right)=0.984 \pm 0.035$, for the two samples, as expected. This indicated that the methods used for analytical corrections, column chemistry and the calibrated spike concentrations give true isotopic values for samples processed by the methods outlined above. Procedural blanks, (including dissolution) and column blanks measured using the Nu Attom ICP-MS indicated that procedural blanks were $0.68 \mathrm{pg}$ of $\mathrm{U}$ and $3.81 \mathrm{pg}$ of Th, and column blank blanks contributed $1.73 \mathrm{pg}$ of $\mathrm{U}$ and $3.67 \mathrm{pg}$ of Th.

All error propagation used two sigma percent errors and error on the individual ratios was calculated as the sum of the internal and external errors as presented above. Final activity ratios used the decay constants of Cheng et al. (2000). Age calculations were done using the program Isoplot (Ludwig, 2003a,b). Typically samples with $\left({ }^{230} \mathrm{Th} /{ }^{232} \mathrm{Th}\right)<20$ require a detrital Th correction to be applied to the age. The Total Sample Dissolution (TSD hereafter) approach (Bischoff and Fitzpatrick, 1991; Luo and $\mathrm{Ku}, 1991$; Ku et al., 1998; Ku, 2000) has previously been applied to samples with $\left({ }^{230} \mathrm{Th} /{ }^{232} \mathrm{Th}\right)<20$. The $\mathrm{U}$ and $\mathrm{Th}$ isotopic compositions of at least three coeval samples are plotted on two isochrons (e.g. $\left({ }^{234} \mathrm{U} /{ }^{232} \mathrm{Th}\right)$ vs. $\left({ }^{230} \mathrm{Th} /{ }^{232} \mathrm{Th}\right)$ and $\left({ }^{238} \mathrm{U} /{ }^{232} \mathrm{Th}\right) \mathrm{vs}$. $\left.\left({ }^{230} \mathrm{Th} /{ }^{232} \mathrm{Th}\right)\right)$ to obtain the detrital-corrected $\left({ }^{230} \mathrm{Th} /{ }^{238} \mathrm{U}\right)$ and $\left({ }^{234} \mathrm{U} /{ }^{238} \mathrm{U}\right)$ value from the slope of the linear least squares regression. Geochronologic studies of tufa (Lin et al., 1996; Garnet et al., 2003) and evaporites (Ku et al., 1998) employed this approach. The second widely used approach is to assume that the sample's initial $\left({ }^{230} \mathrm{Th} /{ }^{232} \mathrm{Th}\right)$ $\left({ }^{234} \mathrm{U} /{ }^{232} \mathrm{Th}\right)$ and $\left({ }^{238} \mathrm{Th} /{ }^{232} \mathrm{Th}\right)$ are equal to those of either (1) a second, measured and related sample, such as pure detritus, or (2) an assumed isotopic composition such as the average crustal ${ }^{232} \mathrm{Th} /{ }^{238} \mathrm{U}$ (Ludwig and Titterington, 1994). For this study the latter was 
used, and a Bulk Silicate Earth (BSE hereafter) detrital correction was applied by assuming a ${ }^{230} \mathrm{Th} /{ }^{232} \mathrm{Th}$ ratio equal to that of bulk silicate earth $\left(4.46 \times 10^{6} \pm 2.23(2 \sigma)\right)$ and $\mathrm{a}^{232} \mathrm{Th} /{ }^{238} \mathrm{U}$ of $3.8 \pm 1.9(2 \sigma)$. See Appendices, Section 7.3 for additional explanation of the BSE and TSD detrital corrections, as well as the derivation of equations for the TSD method.

\subsection{2 $\delta^{18} \mathrm{O}, \delta^{13} \mathrm{C}$ and $\mathrm{Sr} / \mathrm{Ca}$ Analyses}

Both $\delta^{18} \mathrm{O}$ and $\delta^{13} \mathrm{C}$ were measured against a known carbonate standard, Vienna PeeDee Belemnite (hereafter denoted as VPDB). Measurements were made at the Stable Isotope Biogeochemistry Laboratory at Stanford University. Using 0.05-0.1 mg of crushed sample, the sample is reacted with orthophosphoric acid at $70{ }^{\circ} \mathrm{C}$ in a Thermo Finnigan Kiel III Carbonate Device and measured on a dual inlet Thermo Finnigan MAT 252 stable isotope mass spectrometer. Typical internal precision of the instrument is $<0.06 \%$ for $\delta^{18} \mathrm{O}$ and $<0.03 \%$ for $\delta^{13} \mathrm{C}$ analyses.

$\mathrm{Sr}$ and $\mathrm{Ca}$ concentrations in carbonate were measured on a Thermo Scientific ICAP 6300 Duo View Spectrometer equipped with a Solid State CID Detector at the Environmental Measurements 1 Laboratory at Stanford University. Following the procedures outlined by Davis et al., (2009), 10-100 mg of crushed sample were digested in $14 \mathrm{~N} \mathrm{HNO}_{3}$, diluted with $10 \mathrm{~mL}$ of $2 \% \mathrm{HNO}_{3}$, sonicated, centrifuged and filtered through $0.45 \mu \mathrm{m}$ polyethylene filters. Following filtration, $750 \mu \mathrm{L}$ was further diluted by adding $6.75 \mathrm{~mL}$ of $2 \% \mathrm{HNO}_{3}$ (corresponding to a 10 to 1 dilution). Total dissolved $\mathrm{Ca}$ and $\mathrm{Sr}$ were measured at wavelengths $316.9 \mathrm{~nm}$ and $346.4 \mathrm{~nm} / 421.5 \mathrm{~nm}$ respectively. The Sr concentrations were taken as the average of both wavelengths. The $421.5 \mathrm{~nm}$ concentrations are $99.88 \pm 0.10 \%$ of the $346.4 \mathrm{~nm}$ concentrations, with high correlation among samples and standards $\left(\mathrm{R}^{2}=0.99\right)$. Finally, the analyses of error associated with sample preparation blanks $(\mathrm{Ca}, 2 \sigma=0.17 \%$; $\mathrm{Sr}, 2 \sigma=0.40 \%$ ), and analytical error derived from known standard solutions $(\mathrm{Ca}, 2 \sigma=2.05 \%$; $\operatorname{Sr} 2 \sigma=1.75 \%)$ indicate that total standard error $(2 \sigma)$ was $2.73 \%$ for the $\mathrm{Sr} / \mathrm{Ca}$ ratios. Procedural and analytical blanks were subtracted from the concentrations. 


\section{RESULTS}

\subsection{Elevation Transects}

Where tufa samples were collected, elevation data constrain the lake levels. In addition, multiple transects were carried out to more accurately measure the laterally continuous elevations of lake levels in Surprise Valley. This method was of limited utility because the handheld GPS does not accurately measure elevation. However, the handheld GPS does record latitude-longitude accurately (within 5 to $8 \mathrm{~m}$ ). Thus, instead of using the raw GPS elevations, the latitude-longitude waypoints were imported into ArcGIS and I extracted elevations using a digital elevation model (DEM) by pinning the latitudelongitude co-ordinates to the DEM surface. The elevations extracted from the continuous transect, T-USGS, obtained from Dr. Jonathan Glen correlated well with the average elevation measurements from the handheld GPS/DEM method. Table 1 and Figure 5 summarize the eleven major shoreline elevations identified as laterally continuous among the eight GPS transects (T1 to T8), and the continuous transect (T-USGS) conducted as part of this study (location of transects are given in Figure 2B).

Despite the limitations of the handheld GPS used in this study, the elevations obtained by pinning the latitude-longitude coordinates to a DEM appear to have reproduced elevations found by previous work and for the continuously measured transect. A previous study by Zimbelman et al. (2009), using the shoreline features at the south end of Surprise Valley as an analog for potential pluvial landforms observed on Mars as a means calibrate proposed satellite laser altimeters, identified major shoreline features at $1428 \mathrm{~m}, 1448 \mathrm{~m}, 1458 \mathrm{~m}$ and $1476 \mathrm{~m}$, and measured the highstand at 1533.6 m. Elder and de la Fuente (2009) estimated a similar highstand elevation of $1530 \mathrm{~m}$ at the north end of Surprise Valley by analyzing modern day Lake Annie. This highstand elevation is lower than that found in this study $(1565.5 \mathrm{~m})$ and reported by Reheis (1999b) at $1567 \mathrm{~m}$. While this apparent difference in elevation could be due to isostatic rebound of the crust, such as that observed $(22 \mathrm{~m})$ to south at the much larger ancient Lake Lahontan (Adams et al., 1999), the elevations recorded by this study and Zimbelman et al., (2009) appear to correlate well. Zimbelman et al, (2009) have identified elevations near or within error of shoreline numbers 2, 4, 5, 6 and 9 measured for this study (see Table 1).

Isostatic rebound would increase elevation measurements made in the center of the valley (this study) more than the measurements made at the north (Elder and de la 
Fuente, 2009) and south (Zimbelman et al., 2009) of Surprise Valley. Preliminary modeling of the isostatic rebound of the lake indicate that it would require a very thin, elastic lithospheric plate $(\sim 5 \mathrm{~km})$ to produce the $>30 \mathrm{~m}$ of isostatic rebound required to reproduce the discrepancy (Egger and Huerta, personal communication, 2011), which is unlikely. Additionally, late Pleistocene to Holocene fault motion may have offset the shoreline sets from different basalt dip slopes (Oldow and Singleton, 2008). For the purposes of this study, elevation measurements made in the center of Surprise Valley in the accommodation zone, will be used to assess lake level fluctuations in tandem with ${ }^{230} \mathrm{Th}-\mathrm{U}$ ages presented in the following sections.

Table 1. Average Identified Shoreline Elevations. Using the elevation transects (found in Appendices Tables A1-8 and plotted in Figure 2) the following eleven shorelines were identified. Shorelines 10 and 11 have no average or standard deviation because they were only observed at the top of transect 1.

\begin{tabular}{ccccc}
\hline Shoreline & $\begin{array}{c}\text { Elevation } \\
\text { Range }(\mathrm{m})\end{array}$ & $\begin{array}{c}\text { Average } \\
\text { Elevation }(\mathrm{m})\end{array}$ & $\begin{array}{c}\text { Standard } \\
\text { Deviation, } \sigma(\mathrm{m})\end{array}$ & $\begin{array}{c}\text { Elevation from T-USGS } \\
(\mathrm{m})\end{array}$ \\
\hline 1 & $1415.0-1422.5$ & 1418.2 & 2.9 & 1418.069 \\
2 & $1425.4-1433.3$ & 1429.3 & 3.0 & 1423.661 \\
3 & $1438.6-1443.3$ & 1440.6 & 1.7 & 1439.522 \\
4 & $1446.7-1451.5$ & 1448.7 & 2.0 & 1448.822 \\
5 & $1457.4-1461.0$ & 1458.9 & 1.6 & 1454.636 \\
6 & $1468.4-1474.4$ & 1471.5 & 2.2 & 1470.353 \\
7 & $1491.1-1493.8$ & 1492.4 & 1.9 & -- \\
8 & $1513.2-1515.3$ & 1514.1 & 1.0 & -- \\
9 & $1528.2-1532.4$ & 1530.3 & 3.0 & -- \\
10 & 1552.2 & -- & -- & - \\
11 & 1565.6 & -- & -- & - \\
\hline
\end{tabular}




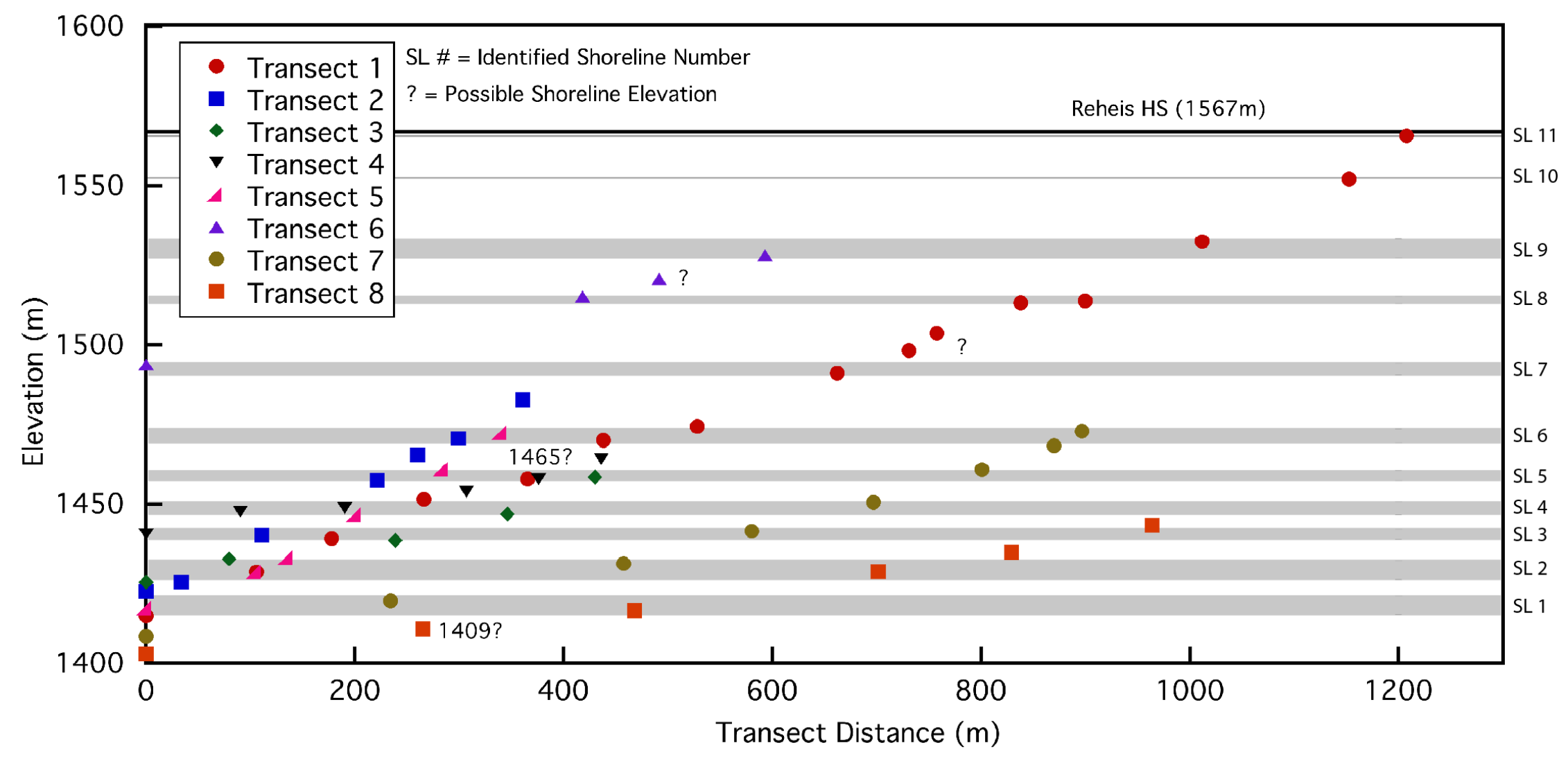

Figure 5. Surprise Valley Elevation Transect Data. Raw elevation and distance from origin from the eight elevation transects used in this study to identify laterally continuous paleo lake levels. Our highest elevation, shoreline number 11 at $1565.6 \mathrm{~m}$, agrees with the elevation reported by Reheis (1999b). Standard deviations (denoted by range of grey bars) are $1 \sigma$, and questions marks indicate possible additional shoreline elevations. 


\section{$4.2{ }^{230}$ Th-U Geochronology}

The measured $U$ and Th isotopic ratios of all samples are presented in Table 2. The ${ }^{238} \mathrm{U}$ and ${ }^{232} \mathrm{Th}$ concentrations of the tufa samples ranged from 0.15 to $5.50 \mathrm{ppm}$ and 0.188 to $1.373 \mathrm{ppm}$ respectively, with $\left({ }^{230} \mathrm{Th} /{ }^{232} \mathrm{Th}\right)$ of 1.7 to 4.5 . To accurately obtain ages on samples with a $\left({ }^{230} \mathrm{Th} /{ }^{232} \mathrm{Th}\right)<20$, the Total Sample Dissolution (TSD) and Bulk Solid Earth (BSE) detrital Th corrections were applied to all measurements. Figure 6 shows the graphical representation of the TSD detrital correction calculation using two plots (e.g. $\left({ }^{234} \mathrm{U} /{ }^{232} \mathrm{Th}\right)$ vs. $\left({ }^{230} \mathrm{Th} /{ }^{232} \mathrm{Th}\right)$ and $\left({ }^{238} \mathrm{U} /{ }^{232} \mathrm{Th}\right)$ vs. $\left.\left({ }^{230} \mathrm{Th} /{ }^{232} \mathrm{Th}\right)\right)$ for each set of apparently coeval samples from Surprise Valley (as outlined in Section 3). Table 3 summarizes the detrital corrected isotope ratios calculated from the slopes of the graphs plotted in Figure 6, and the TSD detrital corrected ages. For comparison, Figure 7 shows $\mathrm{a}^{230} \mathrm{Th}-\mathrm{U}$ isochron diagram with isotope evolution curves and ages for both detrital correction methods.

From Surprise Valley six samples (denoted SVT\#, where \# is the sample number), with three coeval subsamples as replicates, were each analyzed to produce ${ }^{230} \mathrm{Th}-\mathrm{U}$ age using both detrital correction methods. The TSD detrital correction calculation was not successful with SVT2 because the $\left({ }^{230} \mathrm{Th} /{ }^{238} \mathrm{U}\right)>1$, which precludes calculation of an age $\left(\left({ }^{230} \mathrm{Th} /{ }^{238} \mathrm{U}\right) \approx 0.1-0.4\right.$ for young samples such as this). This may be due to preferential $\mathrm{U}$ loss during open system recrystallization. Otherwise, the subsampling of SVT2 may not have been of coeval samples. SVT2 produced BSE detrital corrected ages of $23.61 \pm 4.90$ $\mathrm{ka}$ and $36.69 \pm 4.88 \mathrm{ka}$. For the ages calculated using the BSE detrital correction an error weighted mean age was calculated (Table 2). Comparing the ages obtained from the two methods of dating indicate that the BSE detrital correction (Table 2) and the TSD detrital correction (Table 3) were within error for five of the six samples analyzed SVT4 (31.13 \pm 3.98 ka vs. $30.80 \pm 3.53 \mathrm{ka})$, SVT3 $(31.17 \pm 3.06 \mathrm{ka}$ vs. $32.29 \pm 12.48 \mathrm{ka})$, SVT14 (22.38 $\pm 4.6 \mathrm{ka} v s .23 .07 \pm 2.99 \mathrm{ka})$ and SV17 $(4.64 \pm 1.22 \mathrm{ka}$ vs. $1.75 \pm 2.43 \mathrm{ka})$. For the highest elevation sample, SVT18 the ages produced by the two detrital correction methods disagree considerably $(13.93 \pm 1.21 \mathrm{ka}$ for the BSE detrital correction and 21.99 $\pm 5.45 \mathrm{ka}$ for the TSD detrital correction).

While the ages between the two detrital correction calculations methods are within error of each other, the range in calculated $\left({ }^{234} \mathrm{U} /{ }^{238} \mathrm{U}\right.$ ) initial values (and the measured $\left.\left({ }^{234} \mathrm{U} /{ }^{238} \mathrm{U}\right)\right)$ varies considerably using both methods $(1.217 \pm 0.168$ to $1.964 \pm$ 0.134 for the TSD method and $1.253 \pm 0.014$ to $1.945 \pm 0.101$ for the Bulk Silicate Earth 
method). Additionally, using the BSE detrital correction method appears to substantially reduce the two-sigma error.

Figure 7 demonstrates that the $\left({ }^{234} \mathrm{U} /{ }^{238} \mathrm{U}\right)$ measurements are segregated into two groups, indicating that unless the $\left({ }^{234} \mathrm{U} /{ }^{238} \mathrm{U}\right)$ of the lake water dramatically changed between these time intervals, recrystallization likely occurred when water levels were above previously deposited tufa deposits resulting in open system behavior.

From the Chewaucan Basin three samples from three shoreline elevations $(1333 \mathrm{~m}, 1326 \mathrm{~m}, 1319 \mathrm{~m})$ were analyzed to produce ${ }^{230} \mathrm{Th}-\mathrm{U}$ ages using the BSE detrital correction method (see Table 2). The three detrital corrected ages are within error of each other and increase in age with increased elevation $(24.66 \pm 13.61 \mathrm{ka}, 19.28 \pm 8.53 \mathrm{ka}$ and $19.07 \pm 6.54 \mathrm{ka}$ ) recording the recession of lake level. Additionally, they have similar $\left({ }^{234} \mathrm{U} /{ }^{238} \mathrm{U}\right)_{\text {initial }}$ ratios $(1.897 \pm 0.245,2.149 \pm 0.219$ and $2.154 \pm 0.167)$ indicating closed system evolution, in contrast to several of the Surprise Valley samples. 
Table 2. ${ }^{230}$ Th-U Geochronology Measurements and Bulk Silicate Earth (BSE) Detrital Correction Ages. Detrital corrections were made assuming ${ }^{230} \mathrm{Th} /{ }^{232} \mathrm{Th}$ ratio equal to that of bulk silicate Earth $\left(4.46 \times 10^{6} \pm 2.23(2 \sigma)\right)$ and $\mathrm{a}^{232} \mathrm{Th} /{ }^{238} \mathrm{U}$ of $3.8 \pm 1.9(2 \sigma)$. The weighted mean was taken for each bulk sample's coeval replicates. All age calculations and weighted means were made using decay constants from Cheng et al., (2000) and calculated using Isoplot (Ludwig, 2003a;b). Tufa samples from Surprise Valley (SV) and the Chewaucan Basin's Summer Lake (SL) are denoted using the following convention: SVT\#subsample. The number (\#) is the sample number and the subsamples are the coeval samples taken to apply the TSD detrital correction calculation. (Table continued on next page with BSE detrital corrected ages and error weighted mean ages)

\begin{tabular}{|c|c|c|c|c|c|c|c|c|c|}
\hline \multirow[b]{2}{*}{ Location \& Sample name } & \multirow[b]{2}{*}{$\begin{array}{c}\text { sample } \\
\text { weight } \\
\text { (g) }\end{array}$} & \multirow[b]{2}{*}{$\begin{array}{c}\text { Spike } \\
\text { Weight } \\
\text { (g) }\end{array}$} & \multirow[b]{2}{*}{$\begin{array}{l}\text { 232Th } \\
\text { (ppm) }\end{array}$} & \multirow[b]{2}{*}{$\begin{array}{c}238 \mathrm{U} \\
(\mathbf{p p m})\end{array}$} & \multicolumn{3}{|c|}{ Measured Activity Ratios a,b,c } & \multicolumn{2}{|c|}{ Uncorrected Age ${ }^{\mathrm{d}, \mathrm{c}}$} \\
\hline & & & & & $\left({ }^{230} \mathbf{T h} /{ }^{232} \mathbf{T h}\right)$ & $\left({ }^{230} \mathrm{Th} /{ }^{238} \mathrm{U}\right)$ & $\left({ }^{234} U /{ }^{238} U\right)$ & Uncorrected Age (ka) & $\left({ }^{234} \mathbf{U} /{ }^{238} \mathbf{U}\right)_{\text {initial }}$ \\
\hline$\overline{\text { BZVV } 1}$ & 0.5031 & 0.0162 & & & $3812.23 \pm 76.33$ & $0.979 \pm 0.033$ & $1.000 \pm 0.003$ & & \\
\hline BZVV 2 & 0.5035 & 0.0150 & & & $3997.46 \pm 83.54$ & $0.990 \pm 0.036$ & $1.000 \pm 0.003$ & & \\
\hline \multicolumn{10}{|l|}{ Surprise Valley Samples } \\
\hline SVT4-1a & 1.6057 & 0.0170 & 0.855 & 1.27 & $2.360 \pm 0.019$ & $0.508 \pm 0.006$ & $1.481 \pm 0.014$ & $44.56 \pm 0.85$ & $1.546 \pm 0.016$ \\
\hline SVT4-1b & 1.6057 & 0.0450 & 0.539 & 1.03 & $2.911 \pm 0.026$ & $0.487 \pm 0.007$ & $1.513 \pm 0.007$ & $41.22 \pm 0.74$ & $1.576 \pm 0.008$ \\
\hline SVT4-1c & 1.6057 & 0.0316 & 1.373 & 1.35 & $1.698 \pm 0.027$ & $0.553 \pm 0.025$ & $1.370 \pm 0.013$ & $54.72 \pm 3.19$ & $1.433 \pm 0.015$ \\
\hline SVT3-1 $\mathrm{a}^{\mathrm{e}}$ & 1.2881 & 0.0235 & 0.417 & 0.77 & $2.928 \pm 0.179$ & $0.508 \pm 0.047$ & $1.511 \pm 0.008$ & $43.46 \pm 4.83$ & $1.578 \pm 0.012$ \\
\hline SVT3-1a-Thdup & 1.2881 & 0.0235 & 0.400 & 0.77 & $2.988 \pm 0.027$ & $0.497 \pm 0.007$ & $1.511 \pm 0.008$ & $42.32 \pm 0.76$ & $1.576 \pm 0.009$ \\
\hline SVT3-2a & 2.0287 & 0.0383 & 0.688 & 1.22 & $2.844 \pm 0.028$ & $0.514 \pm 0.008$ & $1.537 \pm 0.015$ & $43.13 \pm 0.92$ & $1.607 \pm 0.016$ \\
\hline SVT3-3a & 1.1865 & 0.0221 & 0.446 & 0.67 & $2.410 \pm 0.085$ & $0.513 \pm 0.028$ & $1.466 \pm 0.008$ & $45.64 \pm 3.01$ & $1.531 \pm 0.010$ \\
\hline SVT2-2a ${ }^{\mathrm{f}}$ & 1.0069 & 0.0134 & 0.359 & 0.70 & $2.562 \pm 0.024$ & $0.421 \pm 0.006$ & $1.575 \pm 0.007$ & $33.20 \pm 0.57$ & $1.632 \pm 0.008$ \\
\hline SVT2-1a ${ }^{\mathrm{f}}$ & 1.2243 & 0.0152 & 0.318 & 0.64 & $3.496 \pm 0.028$ & $0.556 \pm 0.007$ & $1.582 \pm 0.008$ & $45.78 \pm 0.74$ & $1.663 \pm 0.008$ \\
\hline SVT14-1a-1 & 0.2919 & 0.0247 & 0.225 & 0.24 & $1.707 \pm 0.018$ & $0.516 \pm 0.008$ & $1.656 \pm 0.005$ & $39.51 \pm 0.75$ & $1.734 \pm 0.006$ \\
\hline SVT14-1a-2 & 0.5016 & 0.0136 & 0.188 & 0.29 & $2.241 \pm 0.021$ & $0.471 \pm 0.007$ & $1.732 \pm 0.005$ & $33.75 \pm 0.60$ & $1.805 \pm 0.006$ \\
\hline SVT14-1 $c^{e}$ & 0.6356 & 0.0189 & 0.756 & 0.40 & $1.902 \pm 0.017$ & $1.157 \pm 0.016$ & $1.732 \pm 0.005$ & $108.34 \pm 2.38$ & $1.994 \pm 0.009$ \\
\hline SVT17-1a-1 ${ }^{\mathrm{e}}$ & 0.8913 & 0.0689 & 0.277 & 1.46 & $1.755 \pm 0.018$ & $0.106 \pm 0.002$ & $1.240 \pm 0.004$ & $9.72 \pm 0.16$ & $1.246 \pm 0.004$ \\
\hline SVT17-1a-1-Thdup & 0.8913 & 0.0689 & 0.281 & 1.46 & $1.735 \pm 0.018$ & $0.107 \pm 0.002$ & $1.240 \pm 0.004$ & $9.76 \pm 0.17$ & $1.246 \pm 0.004$ \\
\hline SVT17-1a-2 & 1.3491 & 0.0490 & 0.592 & 4.20 & $1.815 \pm 0.015$ & $0.082 \pm 0.001$ & $1.244 \pm 0.004$ & $7.36 \pm 0.12$ & $1.249 \pm 0.004$ \\
\hline SVT17-1b ${ }^{g}$ & 0.1067 & 0.0186 & 0.095 & 0.15 & $1.486 \pm 0.015$ & $0.292 \pm 0.004$ & $1.283 \pm 0.004$ & $27.84 \pm 0.47$ & $1.306 \pm 0.004$ \\
\hline SVT18-1d ${ }^{\mathrm{e}, \mathrm{g}}$ & 1.8064 & 0.0465 & 0.599 & 5.26 & $3.187 \pm 0.106$ & $0.116 \pm 0.006$ & $1.254 \pm 0.012$ & $10.50 \pm 0.58$ & $1.262 \pm 0.012$ \\
\hline SVT18-1c & 1.7331 & 0.0457 & 0.666 & 5.09 & $4.533 \pm 0.050$ & $0.189 \pm 0.003$ & $1.235 \pm 0.012$ & $18.03 \pm 0.39$ & $1.247 \pm 0.013$ \\
\hline SVT18-1e & 2.6690 & 0.0704 & 0.947 & 5.50 & $3.350 \pm 0.065$ & $0.184 \pm 0.006$ & $1.242 \pm 0.012$ & $17.35 \pm 0.68$ & $1.255 \pm 0.012$ \\
\hline SVT18-1e-Thdup & 2.6690 & 0.0704 & 0.878 & 5.50 & $3.522 \pm 0.043$ & $0.179 \pm 0.003$ & $1.242 \pm 0.012$ & $16.88 \pm 0.39$ & $1.254 \pm 0.012$ \\
\hline \multicolumn{10}{|l|}{ Chewaucan Basin Samples } \\
\hline SLT1-2c- $1^{\mathrm{f}}$ & 0.9022 & 0.0112 & 0.503 & 0.38 & $1.417 \pm 0.012$ & $0.597 \pm 0.009$ & $1.543 \pm 0.007$ & $51.51 \pm 0.94$ & $1.628 \pm 0.008$ \\
\hline SLT2- $1^{\mathrm{f}}$ & 1.3738 & 0.0178 & 0.426 & 0.41 & $1.582 \pm 0.017$ & $0.526 \pm 0.009$ & $1.787 \pm 0.008$ & $36.89 \pm 0.71$ & $1.874 \pm 0.009$ \\
\hline SLT3- $1 b^{f}$ & 1.0957 & 0.0181 & 0.269 & 0.32 & $1.812 \pm 0.018$ & $0.490 \pm 0.007$ & $1.847 \pm 0.008$ & $32.71 \pm 0.58$ & $1.929 \pm 0.009$ \\
\hline
\end{tabular}




\section{Table 2. (Continued)}

Detrital Corrected Age

Weighted Mean Age

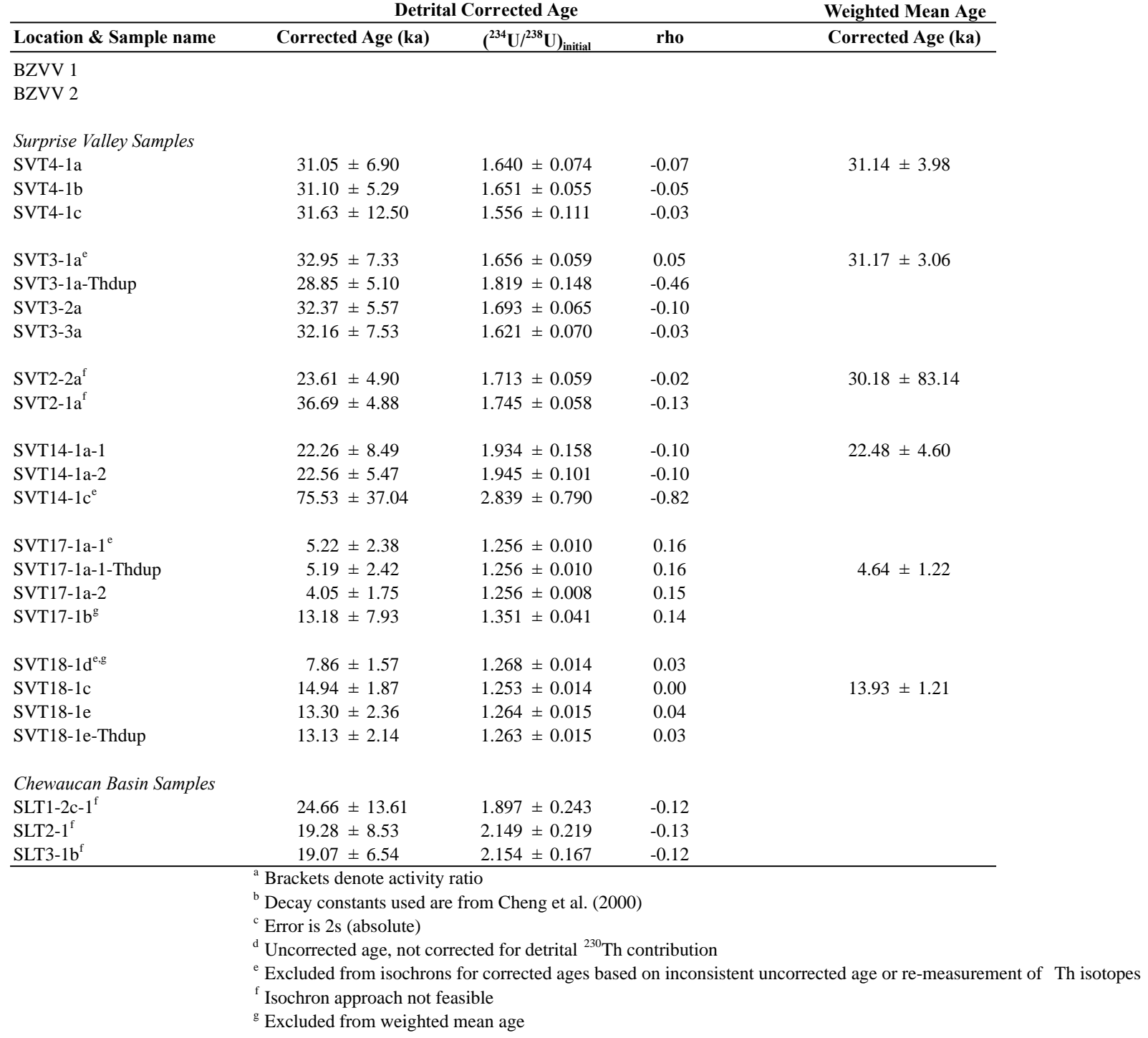


Figure 6. Isochron Plots Calculating Detrital Corrected Activity Ratios. The TSD detrital correction calculation was applied to five samples from Surprise Valley (SVT4, SVT3, SVT14, SVT17 and SVT18). The values for the slopes (equations for U and W) of $\left({ }^{230} \mathrm{Th} /{ }^{234} \mathrm{U}\right)_{\text {authigenic }}$ and $\left({ }^{234} \mathrm{U} /{ }^{238} \mathrm{U}\right)_{\text {authigenic }}$ are calculated using a least squares regression. Similar to Lou and $\mathrm{Ku}$ (1991) and Ku et al. (1998), the least squares fit does not consider error-weighting and correlation of the measured activity ratios. The least square regressions and error calculations were carried out in Isoplot (Ludwig, 2003a;b).

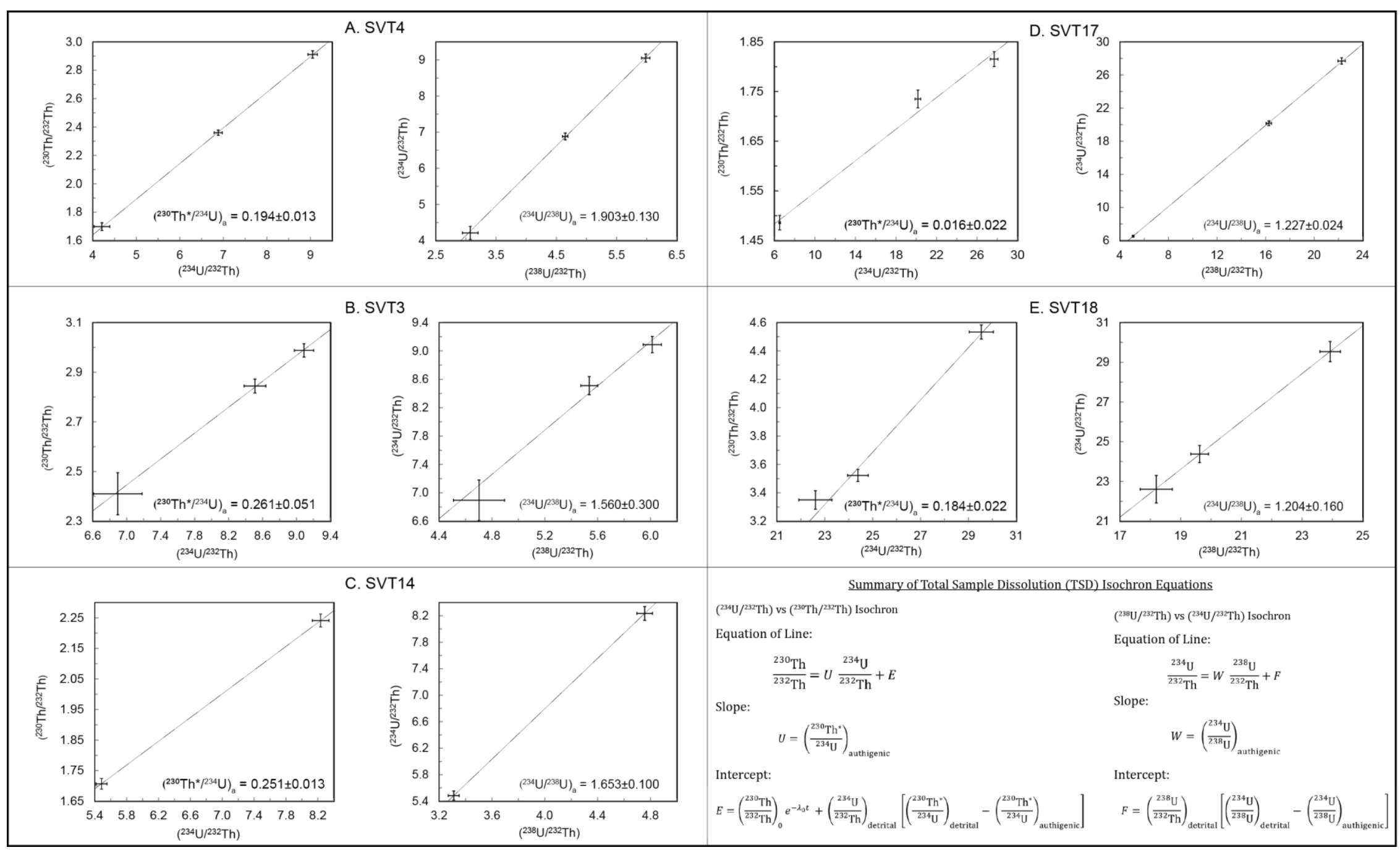


Table 3. Total Sample Dissolution (TSD) Detrital Correction Activity Ratios and Ages. TSD calculated detrital corrected activity ratios $\left.{ }^{230} \mathrm{Th} /{ }^{234} \mathrm{U}\right)_{\text {authigenic }}$ and $\left({ }^{234} \mathrm{U} /{ }^{238} \mathrm{U}\right)_{\text {authigenic }}$ are calculated from the slope of a linear least squares regression (Figure 6) for each set of coeval replicates. $\left.{ }^{230} \mathrm{Th} /{ }^{238} \mathrm{U}\right)_{\text {authigenic }}$ is calculated by multiplying the two detrital corrected activity ratios together. These activity ratios are then used to calculate a detrital corrected age. The weighted linear least squares regression and age calculates were carried out on Isoplot (Ludwig, 2003a;b).

Isochron Calculated Activity Ratios ${ }^{\mathrm{a}, \mathrm{b}}$ Detrital Corr ected Age ${ }^{\mathrm{b}}$

\begin{tabular}{|c|c|c|c|c|c|c|c|c|}
\hline & Shoreline No. & Elevation (m) & $\left({ }^{230} \mathrm{Th} /{ }^{234} \mathrm{U}\right)_{\text {authigenic }}$ & $\left({ }^{234} \mathbf{U} /{ }^{238} \mathbf{U}\right)_{\text {authigenic }}$ & $\left({ }^{230} \mathbf{T h} /{ }^{238} \mathbf{U}\right)_{\text {authigenic }}$ & Age (ka) & $\left({ }^{234} \mathbf{U} /{ }^{238} U\right)_{\text {initial }}$ & rho \\
\hline SVT4 & 2 & 1429 & $0.194 \pm 0.013$ & $1.903 \pm 0.130$ & $0.369 \pm 0.035$ & $30.80 \pm 3.53$ & $1.713 \pm 0.105$ & -0.57 \\
\hline SVT3 & 3 & 1441 & $0.261 \pm 0.051$ & $1.560 \pm 0.300$ & $0.407 \pm 0.112$ & $32.29 \pm 12.48$ & $1.614 \pm 0.316$ & -0.54 \\
\hline SVT14 & 6 & 1472 & $0.251 \pm 0.013$ & $1.653 \pm 0.100$ & $0.415 \pm 0.033$ & $23.07 \pm 2.99$ & $1.964 \pm 0.134$ & -0.55 \\
\hline SVT17 & 8 & 1514 & $0.016 \pm 0.022$ & $1.227 \pm 0.024$ & $0.020 \pm 0.027$ & $1.75 \pm 2.43$ & $1.228 \pm 0.024$ & 0.05 \\
\hline SVT18 & 10 & 1552 & $0.184 \pm 0.022$ & $1.204 \pm 0.160$ & $0.222 \pm 0.040$ & $21.99 \pm 5.45$ & $1.217 \pm 0.168$ & -0.59 \\
\hline
\end{tabular}



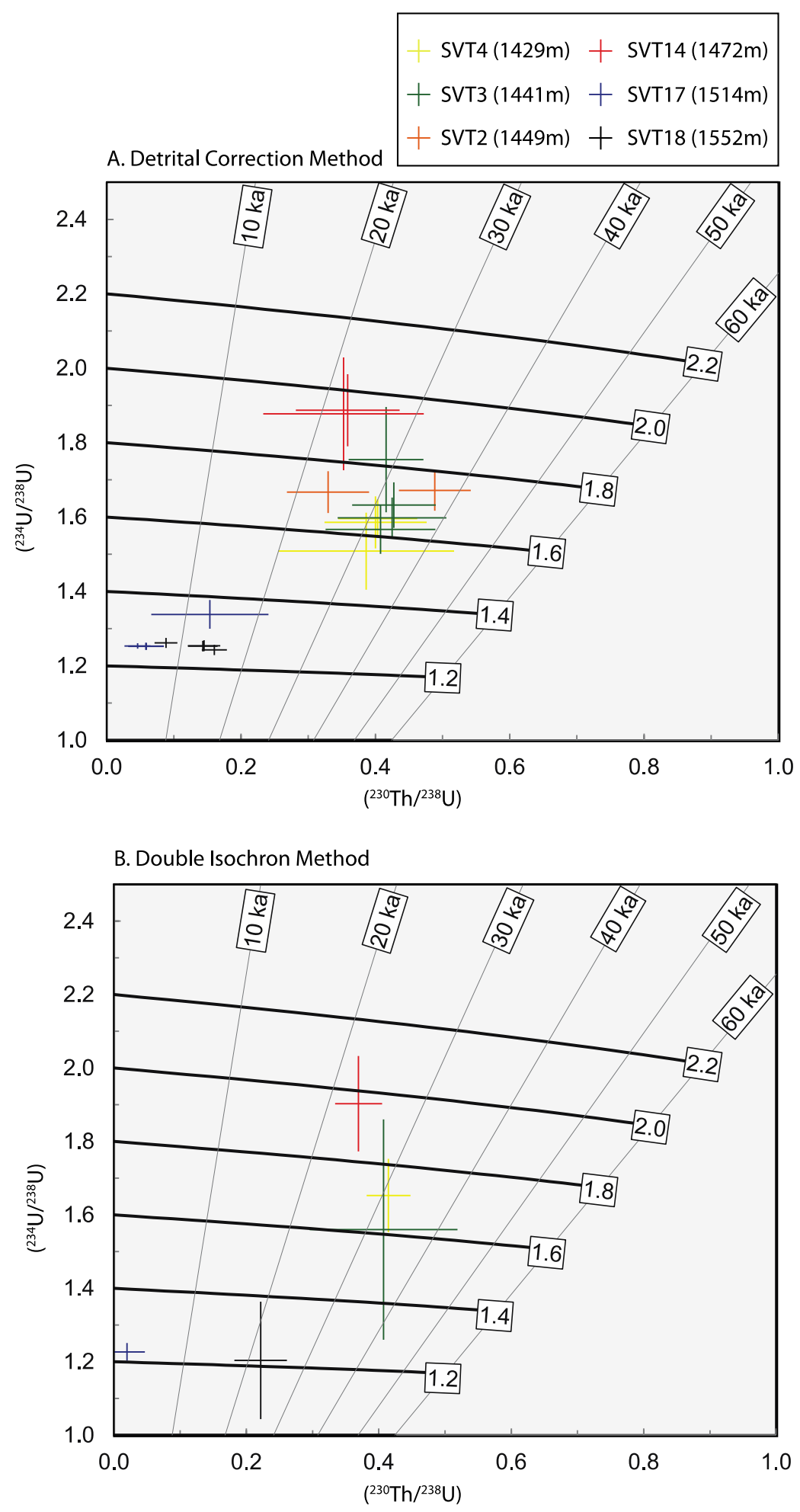

Figure 7. Isochrons $\left(\left({ }^{230} \mathbf{T h} /{ }^{238} \mathrm{U}\right)\right.$ vs. $\left.\left.{ }^{234} \mathrm{U} /{ }^{238} \mathrm{U}\right)\right)$ for Surprise Valley Tufa Samples. (A) BSE detrital corrected $\left.{ }^{230} \mathrm{Th} /{ }^{238} \mathrm{U}\right)$ and $\left({ }^{234} \mathrm{U} /{ }^{238} \mathrm{U}\right)$ for each subsample. The ages of these subsamples produced one age for the BSE detrital correction using an error weighted mean calculation using Isoplot (Ludwig, 2003a;b). (B) TSD detrital corrected $\left({ }^{230} \mathrm{Th} /{ }^{238} \mathrm{U}\right)$ and $\left({ }^{234} \mathrm{U} /{ }^{238} \mathrm{U}\right)$ for each set of coeval samples used to calculated a detrital corrected age (Table 3). Figures were made using Isoplot (Ludwig, 2003a;b). The data points are color coded by sample $($ SVT4 $=$ yellow, SVT3 $=$ green, SVT2 $=$ orange, SVT14 $=$ red, SVT17 = blue, SVT18 = black). The TSD detrital correction was not applied to SVT2 due to $\left({ }^{230} \mathrm{Th} /{ }^{238} \mathrm{U}\right)>1$, calculated from the slopes (as calculated for other samples in Figure 6). 


\section{$4.3 \delta^{18} \mathrm{O}, \delta^{13} \mathrm{C}$ and $\mathrm{Sr} / \mathrm{Ca}$ Analyses}

Eleven samples from Surprise Valley were analyzed for $\delta^{13} \mathrm{C}$ and $\delta^{18} \mathrm{O}$ and the results of these analyses are presented in Table 3 . The $\delta^{13} \mathrm{C}$ varied from $-6.142 \%$ to $4.103 \%$ and $\delta^{18} \mathrm{O}$ varied from $-12.559 \%$ o to $-2.501 \%$ (VPDB).

Table 4. Summary of $\delta^{18} \mathrm{O}$ and $\delta^{13} \mathrm{C}$ Analyses for Surprise Valley Tufa Samples.

\begin{tabular}{ccccc}
\hline Sample ID & Shoreline No & Mass Analyzed $(\mathrm{mg})$ & $\delta^{13} \mathrm{C}_{\mathrm{VPDB}}(\%)$ & $\delta^{18} \mathrm{O}_{\text {VPDB }}(\%)$ \\
\hline SVT4-1a & 2 & 0.099 & 3.866 & -3.123 \\
SVT4-1b & 2 & 0.096 & 3.472 & -3.385 \\
SVT3-1a & 3 & 0.095 & 3.282 & -4.045 \\
SVT3-2 & 3 & 0.105 & 3.302 & -2.988 \\
SVT2-Inn & 4 & 0.089 & 4.103 & -2.501 \\
SVT2-Out & 4 & 0.068 & 3.598 & -2.851 \\
SVT14-1a & 6 & 0.073 & 3.789 & -3.238 \\
SVT14-1c & 6 & 0.070 & 3.690 & -3.225 \\
SVT17-1a & 8 & 0.067 & -6.218 & -10.814 \\
SVT17-1b & 8 & 0.053 & -4.748 & -11.493 \\
SVT18-1e & 10 & 0.083 & -6.142 & -12.559 \\
\hline
\end{tabular}

In general $\delta^{18} \mathrm{O}$ and $\delta^{13} \mathrm{C}$ are more depleted with increasing elevation (Figure 8A). Additionally, the relationship of $\delta^{18} \mathrm{O}$ vs. $\delta^{13} \mathrm{C}$ for each data point (Figure 8B) demonstrates that they covary with a high correlation coefficient $\left(\mathrm{R}^{2}=0.979\right)$.

Eleven samples were measured for $\mathrm{Ca}$ and $\mathrm{Sr}$ concentrations in order to obtain $\mathrm{Sr} / \mathrm{Ca}$ ratios. Sr concentrations vary from 1.01 to $59.60 \mu \mathrm{g} / \mathrm{mL}$, Ca concentrations vary from 14.56 to $223.73 \mathrm{mg} / \mathrm{mL}$ and $1000 * \mathrm{Sr} / \mathrm{Ca}$ vary from 0.64 to $3.56(\mu \mathrm{g} / \mathrm{mg})$.

Table 5. Summary of Sr and Ca Analyses for Surprise Valley Tufa Samples. Total analytical error on the $\mathrm{Sr} / \mathrm{Ca}$ ratios is $2.73 \%(2 \sigma)$.

\begin{tabular}{cccccc}
\hline Sample ID & $\begin{array}{c}\text { Shoreline } \\
\text { No }\end{array}$ & $\begin{array}{c}\text { Mass Analyzed } \\
(\mathrm{g})\end{array}$ & $\mathrm{Sr}(\mu \mathrm{g} / \mathrm{mL})$ & $\mathrm{Ca}(\mathrm{mg} / \mathrm{mL})$ & $\begin{array}{c}1000 * \mathrm{Sr} / \mathrm{Ca} \\
(\mu \mathrm{g} / \mathrm{mg})\end{array}$ \\
\hline SVT4-1a & 2 & 0.0220 & 39.35 & 152.43 & 2.58 \\
SVT4-1b & 2 & 0.0125 & 22.55 & 87.77 & 2.57 \\
SVT3-1a & 3 & 0.0207 & 18.12 & 68.91 & 2.63 \\
SVT3-2 & 3 & 0.0295 & 59.60 & 223.73 & 2.66 \\
SVT2-Inn & 4 & 0.0090 & 16.88 & 69.97 & 2.41 \\
SVT2-Out & 4 & 0.1036 & 17.26 & 65.53 & 2.63 \\
SVT14-1a & 6 & 0.0072 & 15.51 & 43.54 & 3.56 \\
SVT14-1c & 6 & 0.0057 & 11.07 & 31.09 & 3.56 \\
SVT17-1a & 8 & 0.0062 & 2.05 & 32.27 & 0.64 \\
SVT17-1b & 8 & 0.0032 & 1.01 & 14.56 & 0.70 \\
SVT18-1e & 11 & 0.0370 & 26.14 & 168.03 & 1.56 \\
\hline
\end{tabular}

$\mathrm{Sr} / \mathrm{Ca}$ ratios decrease with increasing shoreline elevation (Figure 8C).

Additionally, the relationship of $\delta^{18} \mathrm{O}$ vs. Sr/Ca for each data point (Figure 8D) demonstrates that the two geochemical proxies correlate well $\left(\mathrm{R}^{2}=0.720\right)$ with $\delta^{18} \mathrm{O}$ being more depleted and $\mathrm{Sr} / \mathrm{Ca}$ ratios decreasing with increasing shoreline elevation. 


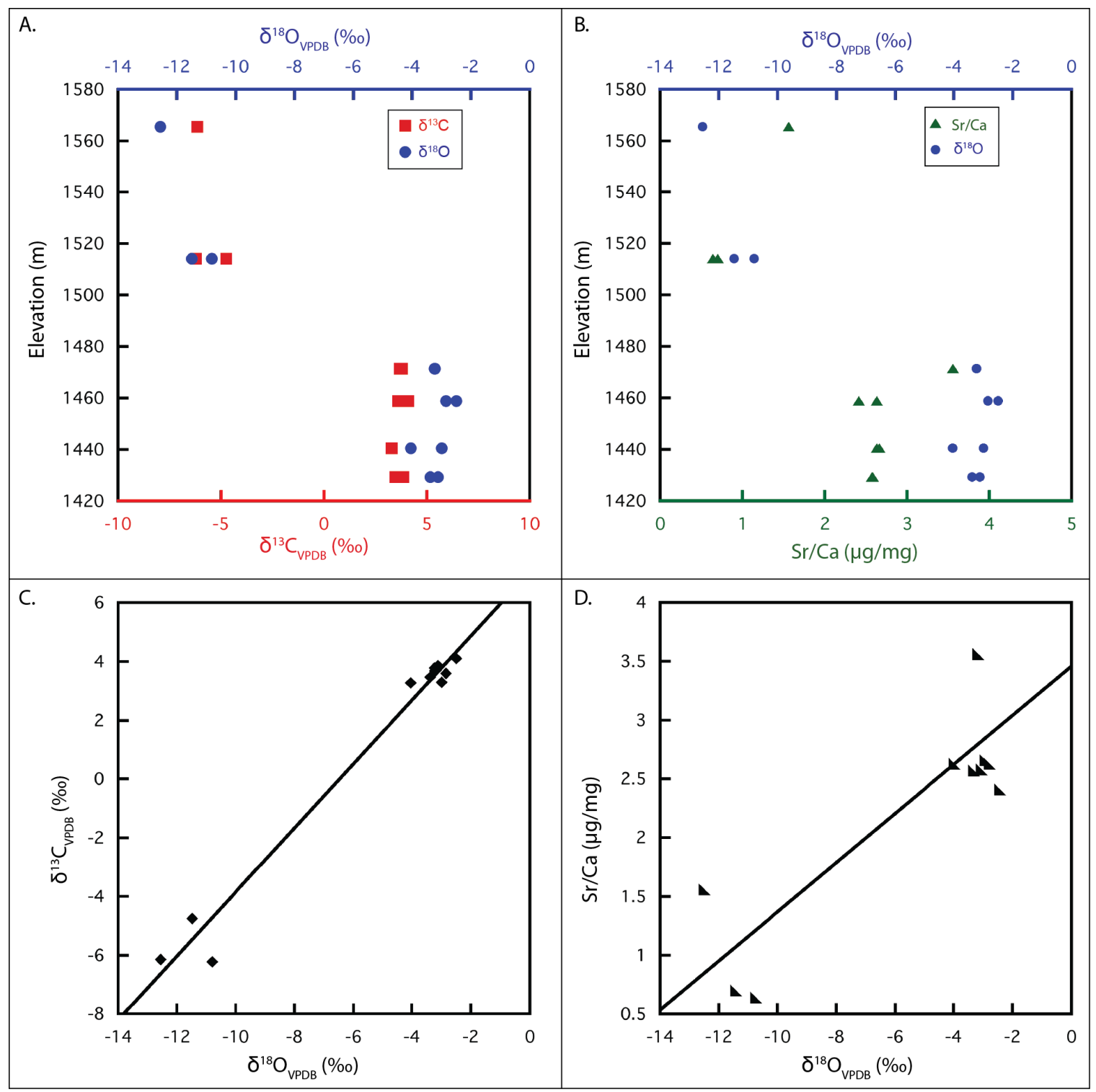

Figure 8. $\delta^{18} \mathrm{O}, \delta^{13} \mathrm{C}$ and $\mathrm{Sr} / \mathrm{Ca}$ Measurements from Surprise Valley Tufa. Stable and elemental measurements obtained on tufa samples from Surprise Valley. (A) $\delta^{18} \mathrm{O}$ (blue circle) and $\delta^{13} \mathrm{C}$ (red square) measurements vs. tufa sample elevation. (B) $\delta^{18} \mathrm{O}$ (blue circle) and $\mathrm{Sr} / \mathrm{Ca}$ (green triangle) measurements vs. tufa sample elevation. (C) $\delta^{18} \mathrm{O}$ vs. $\delta^{13} \mathrm{C}$ plot showing strong correlation $\left(\mathrm{R}^{2}=0.979\right)$ between the measurements. (D) $\delta^{18} \mathrm{O}$ vs. Sr/Ca plot showing correlation $\left(\mathrm{R}^{2}=0.720\right)$ between the measurements. Linear least square regressions used to fit data to test for correlation. 


\section{DISCUSSION}

\subsection{Assessing Surprise Valley as a Terminal Basin}

The extent to which the Surprise Valley lake system was a terminal basin, with no outflow or substantial regional groundwater flow in the past, is important for using lake shoreline ages (and other geochemical data) as indicators of past climate. Smaller, closed basin lakes are more likely to respond rapidly to watershed scale changes in precipitation, runoff/infiltration and evaporation (Menking et al., 2004; Garcia and Stokes, 2006). Coupling light stable isotopic and elemental analysis with geochronologic data provides tools to assess whether Lake Surprise was a closed, inward draining pluvial lake as suggested by modern watershed data (Figure $2 \mathrm{~B}$ ). The covariance of $\delta^{18} \mathrm{O}-\delta^{13} \mathrm{C}$ and $\delta^{18} \mathrm{O}$ $\mathrm{Sr} / \mathrm{Ca}$ can also be used to evaluate the role of evaporation in lake systems (Muller et al., 1972; Eugster and Kelts, 1983; Talbots and Kelts, 1990; Davis et al., 2009).

Terminal basin lakes have long residence times, resulting in the evaporative enrichment of ${ }^{18} \mathrm{O}$ in the lake water and preferential outgassing of ${ }^{12} \mathrm{C}$-rich $\mathrm{CO}_{2}$ from the system (Talbot and Kelts, 1990). Evaporative effects on $\delta^{18} \mathrm{O}$ and $\delta^{13} \mathrm{C}$ indicate that if a lake is hydrologically closed, and evaporation is relatively high (as observed in Figure 3B for Surprise Valley's modern climate), the $\delta^{18} \mathrm{O}$ and $\delta^{13} \mathrm{C}$ will covary (Davis et al., 2009; Talbot and Kelts, 1990). Correlation of $\delta^{18} \mathrm{O}$ and $\delta^{13} \mathrm{C}$ demonstrated in Figure 8 shows that with increased shoreline elevation both $\delta^{18} \mathrm{O}$ and $\delta^{13} \mathrm{C}$ are more depleted, consistent with a closed basin (Figure 8A). Additionally, as lake level rose and fell the values of $\delta^{18} \mathrm{O}$ and $\delta^{13} \mathrm{C}$ remained well correlated, $\mathrm{R}^{2}=0.979$ (Figure $8 \mathrm{C}$ ).

Similarly, Sr/Ca ratios have also been used to assess evaporative effects in lake systems (Muller et al., 1972; Davis et al., 2009). Muller et al., (1972) show that for highly evaporative lakes, $\mathrm{Sr} / \mathrm{Ca}$ in carbonates is proportionally correlated to the $\mathrm{Sr}$ and $\mathrm{Ca}$ concentrations in lake water. Additionally, in terminal lake systems, $\mathrm{Sr}$ is not removed as efficiently from the lakewater as $\mathrm{Ca}$, which is taken up by precipitating carbonates, thus $\mathrm{Sr}$ is concentrated when evaporation, relative to lake volume, is high (Eugster and Kelts, 1983; Davis et al., 2009). This correlation is not expected to hold with an open system lake because Sr would be flushed out of the system. At Surprise Valley, increased $\mathrm{Sr} / \mathrm{Ca}$ ratios at lower lake levels (Figure 8B) are well correlated with the increased relative evaporative effects recorded in the $\delta^{18} \mathrm{O}, \mathrm{R}^{2}=0.720$ (Figure 8D), again consistent with a closed basin. 
However, the isotope and elemental data may be biased towards high correlation coefficients by the clustering of the data (Figure 8C and D). The lower elevation cluster (top right corner) give correlation coefficients of $\mathrm{R}^{2}=0.43$ for of $\delta^{18} \mathrm{O}$ vs. $\delta^{13} \mathrm{C}, \mathrm{R}^{2}=0.30$ for of $\delta^{18} \mathrm{O}$ vs. $\mathrm{Sr} / \mathrm{Ca}$. A larger set of samples (ideally from more shoreline elevations) is necessary to further quantify the evaporative effects at Lake Surprise. The expansion of this dataset, if a hydrologically open system is suspected, will elucidate the contributing effects of local hot springs and/or fluxes between the lake and groundwater aquifers (Li et al., 2008a,b).

In addition to the geochemical data, the stream data derived from high-resolution elevation data obtained from NASA's Shuttle Radar Topography Mission, EPA watershed demarcations, and the contoured outline of the Reheis (1999b) highstand, all shown in Figure 2A, demonstrate that topographically the Surprise Valley lake system likely remained a terminal basin throughout its late Pleistocene pluvial history. Additionally, while some overflow into Duck Flat appears to have occurred at the highstand elevation, to the south, the smaller region of overflow also appears to remain a closed based on the outline of the Reheis (1999b) highstand elevation and local topography (Figure 2B). Coupling of the geochemical measurements and geophysical observations supports previous hypotheses (Russell, 1927; Sack, 2002) suggesting that the Surprise Valley lake system remained a terminal basin in the late Pleistocene.

\subsection{Lake Levels of Late Pleistocene to Middle Holocene Lake Surprise}

Linking ${ }^{230} \mathrm{Th}-\mathrm{U}$ geochronology of tufas with elevation data allows for the hydrologic changes of a lake system to be assessed directly by constructing a lake level curve (Figure 9). Rather than using indirect proxies for lake level, such as pollen (e.g. Whitlock et al., 1999; Grigg et al., 2001; Grigg and Whitlock, 2002) or stable isotopes in sedimentary carbonates from lake cores, the absolute dating of materials collected at known elevations provide temporal constraints on the fluctuation of lake systems through time. Corrections for isostatic rebound may be necessary (as discussed previously). However, for smaller lake systems such as Lake Surprise, the correction is likely minimal (Egger and Huerta, personal communication, 2011).

Figure 9 illustrates the lake levels of Lake Surprise from the late Pleistocene to middle Holocene. Both methods of detrital Th correction are plotted in Figure 9, the BSE age calculations yield lower age errors, are internally consistent, and appear to accurately 
correct for relative amounts of detrital Th incorporated into the sample. In the lower elevation samples, both detrital Th correction methods produced ages within error for the same suite of sample measurements. At the highest elevation sample and SVT17, there is a discrepancy of ages between the two detrital Th correction methods. Using the TSD method, the lake level curve suggests an unlikely scenario of lake level doubling (1472 m to $1552 \mathrm{~m}$ ) within only $\sim 1 \mathrm{kyr}$. In contrast, using the BSE detrital Th corrected ages, the doubling of lake level would have occurred over 9.5 kyr during the period from $22.48 \pm$ $4.60 \mathrm{ka}$ to $13.93 \pm 1.21 \mathrm{ka}$, over the middle to latter part of the LGM. The closest age to modern obtained in this study (using the BSE detrital correction method) was $4.64 \pm 1.22$ $\mathrm{ka}$ at $142 \mathrm{~m}$ above the modern valley bottom. Thus, while the transgression of lake level up $1552 \mathrm{~m}$ was recorded temporally in this study, the regression of the lake surface down to modern day levels remains unrecorded beyond the knowledge that the lake was relatively high until $4.64 \pm 1.22 \mathrm{ka}$.

In addition, the data suggests that Lake Surprise was present at moderate water levels (69 to $57 \mathrm{~m}$ deep) well before the LGM, from at least $31.17 \pm 3.06 \mathrm{ka}$. Hence, Lake Surprise was likely present well into the later stages of the last interglacial period (Marine Isotope Stage 3), which was apparently much colder and wetter compared to the modern day interglacial.

The three tufa samples dated from the middle shoreline elevations of the Chewaucan Basin (Figure 10 (h)) all yielded ages within error of each other $(24.66 \pm$ $13.61 \mathrm{ka}, 19.28 \pm 8.53 \mathrm{ka}$, and $19.07 \pm 6.54 \mathrm{ka}$ ). However, the ages do not agree with the published lake level curve produced by Licciardi (2001). Using sediment cores and dating of shoreline materials Licciardi (2001) produced a preliminary curve with high uncertainty during the LGM, the age of the three samples dated in this study. The Chewaucan Basin's lake history is well constrained by ${ }^{14} \mathrm{C}$ dating approaches from the latest highstand at $\sim 13$ ka to the early Holocene, but earlier lake levels during the LGM are poorly constrained (Licciardi, 2001; Negrini, 2002). However, these ages place new constraints on the previously hypothesized (Licciardi, 2001; Negrini, 2002) pluvial period occurring throughout much of MIS 2, and prior to the 13 ka highstand. 


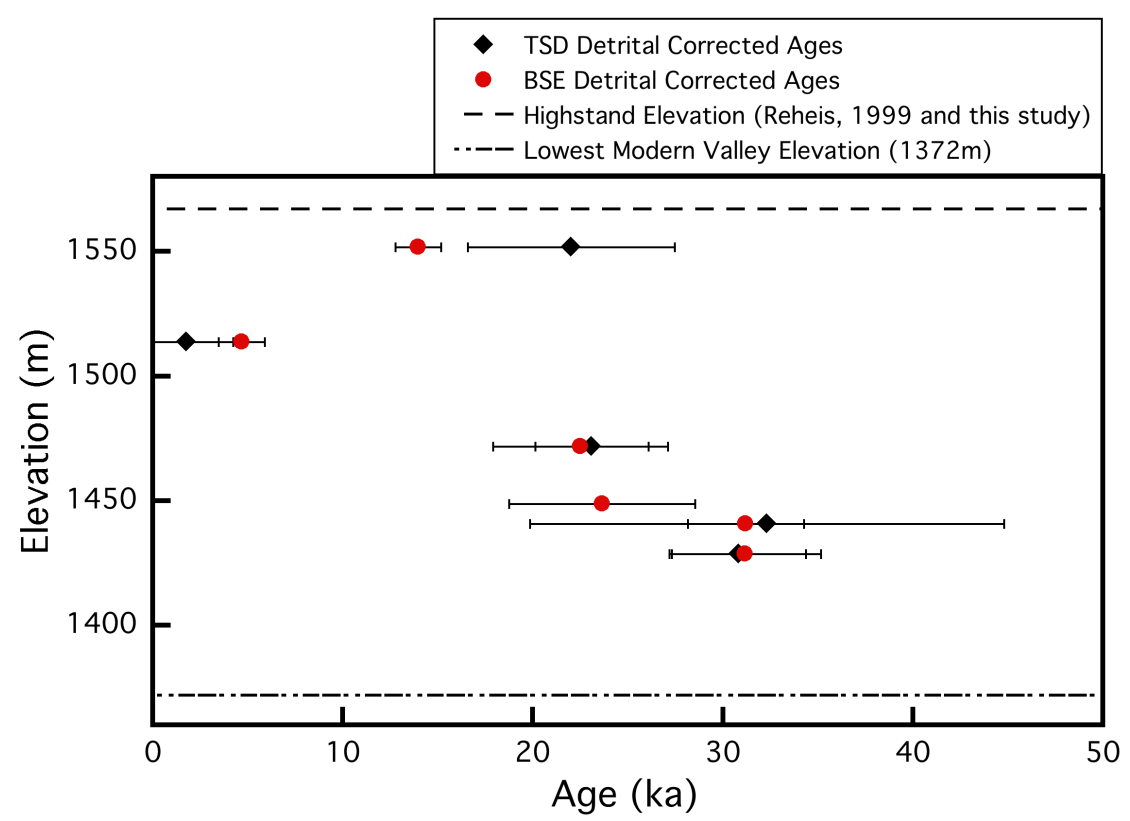

Figure 9. Lake Surprise Lake Level Curve. ${ }^{230}$ Th-U ages calculated using both detrital Th correction methods (Tables 2 and 3, and Figure 7) versus the average elevation of the shoreline that the tufa sample was collected (Table 1 and Figure 5). The highstand elevation observed in this study and reported by Reheis (1999b) is given as the dashed line while the lowest modern valley elevation, found in the middle playa lake, is represented by the dash and dotted line.

\subsection{Comparison of Results to Existing Lake Records and Other Paleoclimate Proxy}

\section{Records}

The high lake level recorded in Surprise Valley at 13.93 ka occurs within error of the Chewaucan Basin stillstand (13.04 ka) to the north (Licciardi, 2001; Negrini, 2002) and after the Lake Lahontan highstand (15.22 ka) to the south (Adams and Wesnousky, 1998; Godsey et al., 2011). The data presented in this study suggests that Lake Surprise remained at a moderate lake level during the LGM, with the lake level peaking after the LGM, similar to the Chewaucan Basin. Table 6 summarizes lake highstands, significant stillstands and hydrologic maxima from western North America. Hydrologic maxima were defined as periods of time when known high lake level occurred in lakes occupying open basins with potential spillover (e.g. Lake Bonneville), or where lake level broadly peaks over longer time periods (e.g. Babicora Basin, Searless Lake and Lake Manly). Most lake highstands in the Basin and Range region occur in the latter portion of the LGM or after the LGM, during the deglaciation period. Lake highstand ages listed in Table 6 (in approximate north to south order) show an approximate northward migration in the timing of the hightstands during the LGM deglaciation. 
Table 6. Western North America Lake Stand Ages. Summary of chronologic data compiled from the shoreline studies. All radiocarbon dates $\left({ }^{14} \mathrm{C}\right.$ Before 1950) have been converted to calendar ages (ka) in order to compare within high stand ages, lake level curves and ${ }^{230} \mathrm{Th}-\mathrm{U}$ ages from studies using ${ }^{230} \mathrm{Th}-\mathrm{U}$ geochronology.

\begin{tabular}{|c|c|c|}
\hline Lake, State & Late Pleistocene Lake Stand Ages $(\mathrm{ka} \pm 1 \sigma)$ & Sources \\
\hline \multirow[t]{2}{*}{ Chewaucan Basin, OR } & $\begin{array}{l}\text { Higher Highstand? } \approx 18.1 \text { to } 15.7 \\
\text { Highstand }-13.04 \pm .69\end{array}$ & Licciardi (2001); Negrini (2002) \\
\hline & $\begin{array}{l}\text { Lower Stillstands }-24.66 \pm 13.61,19.28 \pm \\
8.53 \text { and } 19.07 \pm 6.54\end{array}$ & (This study) \\
\hline Surprise Valley, CA & $\begin{array}{l}\text { Stillstands }-31.17 \pm 3.98 \text { to } 22.48 \pm 4.60 \\
\text { Highstand }-13.93 \pm 1.21 \\
\text { Stillstand }-4.64 \pm 1.22\end{array}$ & This study \\
\hline Lake Bonneville, UT & Hydrologic maximum from 17.57 to 14.45 & $\begin{array}{l}\text { Oviatt et al., (1992); Godsey et } \\
\text { al., (2011) }\end{array}$ \\
\hline Lake Franklin, NV & $\begin{array}{l}\text { Highstand }-19.09 \pm 0.15 \\
\text { Stillstand } 1-15.52 \pm 0.17 \\
\text { Stillstand } 2-14.82 \pm 0.15\end{array}$ & Lillquist (1994) \\
\hline Lake Lahontan, NV & Highstand $-15.223 \pm 1.20$ & Adams and Wesnousky, 1998) \\
\hline Diamond Valley, NV & $\begin{array}{l}\text { Highstand - } 26.54 \pm 0.27 \\
\text { Stillstand - } 15.72 \pm 0.23\end{array}$ & Tackman (1993) \\
\hline Newark Valley, NV & Highstand $-16.024 \pm 1.15$ & $\begin{array}{l}\text { Redwine (2003); Kurth et al., } \\
\text { (2011) }\end{array}$ \\
\hline Jakes Lake, NV & $\begin{array}{l}\text { Highstand }-16.16 \pm 0.13 \\
\text { Stillstand } 1-15.73 \pm 0.12 \\
\text { Stillstand } 2-14.35 \pm 0.13\end{array}$ & Garcia and Stokes (2006) \\
\hline Lake Manly, CA & Hydrologic maximum from 24.7 to 16 & Ku et al., (1998) \\
\hline Searless Lake, CA & Hydrologic maximum from 22.29 to 16.5 & Smith (1984) \\
\hline Lake Estancia, NM & $\begin{array}{l}\text { Highstand } 1-27.66 \pm 0.14 \\
\text { Highstand } 2-21.16 \pm 0.13 \\
\text { Stillstand } 1-16.14 \pm 0.14 \\
\text { Sillstand } 2-14.94 \pm 0.13 \\
\end{array}$ & $\begin{array}{l}\text { Allen and Anderson (2000); } \\
\text { Anderson et al. (2002) }\end{array}$ \\
\hline $\begin{array}{l}\text { San Agustin Basin, } \\
\text { NM }\end{array}$ & Highstand - 22.6 to 25 & Markgraf et al. (1984) \\
\hline $\begin{array}{l}\text { Lower Playas Valley, } \\
\text { NM }\end{array}$ & Highstand - 18.2 & Ballenger et al. (2011) \\
\hline Cloverdale, NM & Highstand -21.5 to 23.9 & Krider (1998) \\
\hline $\begin{array}{l}\text { Babicora Basin, } \\
\text { Mexico }\end{array}$ & Hydrologic maximum from 38 to $\sim 29 \mathrm{ka}$ & Metcalfe et al. (2002) \\
\hline
\end{tabular}

In addition to the apparent northward migration of highstands during the deglaciation, many of the lake record curves (Figure 10) indicate that lake levels were higher before or during the LGM relative to the Holocene or interglacial (MIS 3), followed by a pulse or peak in lake surface height in the latter stages of the LGM or after the LGM. The well-dated records from Lake Bonneville, Lake Lahontan, Searles Lake and Lake Surprise demonstrate this trend. Many authors have postulated a southward deflection of the jet stream and westerly storm tracks with increasing growth of the Laurentide and Cordilleran ice sheets (Negrini, 2002; Benson et al., 1990; Adams and Wesnousky, 1998; Zic et al., 2002). Interpretations of several speleothem records, such as 
the Cave of the Bells record (Wagner et al., 2010) presented in Figure 10 have also invoked the shifting westerly winds as the atmospheric connection between increased rainfall and increased ice sheet extent (Oster et al., 2009; Asmeron et al., 2010).

In addition, southward shifted westerlies in the Northern Hemisphere have been proposed to mirror changes in the Southern Hemisphere westerlies and the inter-tropical convergence zone via synchronous shifts in the three primary circulation cells of Earth's idealized atmospheric circulation model: the Hadley, Ferrel, and Polar cells (Togweiller et al., 2006). Air masses flowing from ca. $30^{\circ} \mathrm{N} / \mathrm{S}$ (high pressure) to ca. $60^{\circ} \mathrm{N} / \mathrm{S}$ (low pressure) in the Ferrel cell are deflected by the Coriolis effect to produce the prevailing westerly winds observed in the mid-latitudes of the Earth's atmosphere (Toggweiler, 2009). Mid-latitude moisture availability is dominated by the westerly wind patterns during Northern Hemisphere winters and is the primary moisture source for pluvial lakes in the Basin and Range. Modern remote sensing analysis and compilation of paleoclimate data indicate that westerly wind patterns and their associated storm tracks correlate with latitudes of maximum precipitation (Moreno et al.1999). Satellite observations and models of future climate (e.g. Shindell and Schmidt, 2003) have also shown a poleward shift of the westerlies in both hemispheres, due to global temperature increases (Salathe, 2006). Furthermore, Southern Hemisphere paleoceanographic records and ice cores suggest southward shifted, strengthened Southern Hemisphere westerlies beginning at 17 ka (Toggweiller et al., 2006; Lamy et al., 2007). Additionally, marine radiocarbon evidence suggests that it was this shift in the strength and position of the westerlies in the Southern Hemisphere that enhanced ventilation of the deep ocean and thus led to increasing atmospheric $\mathrm{CO}_{2}$ (Marchitto et al., 2007), creating a positive feedback loop to warm the Earth and bring it out of the LGM (Toggweiler and Russel, 2008).

Linking south shifted westerlies during glacial periods with a symmetric northward response during deglaciation is attractive because of its synchronous, apparently insolation forced explanation. Denniston et al., (2007) even call for the synchronicity of climate changes between the western United States and the highlatitudes to explain the transmission of far-field atmosphere-ocean interactions in the poles and tropics to temperatures in the Basin and Range. However, with respect to explaining the lag of lake highstands behind peaks in soil P-ET (Maher et al., in prep) (Figure 10) this hypothesis may be too simplistic, neglecting the important effect that decreased temperature and decreased relative humidity may have on evaporation. 
Decreased evaporation would have the same apparent effect of increases in rainfall brought by south shifted westerly storm tracks; particularly in evaporation dominated arid environments, such as Surprise Valley (Figure 3A), surface evaporation should be diminished due to decreased temperatures and increased relative humidity.

Ultimately, ice sheet extent is driven by changes in solar insolation (Figures $10 \mathrm{f}$ and $10 \mathrm{~g}$ ) resulting in changes in atmospheric $\mathrm{CO}_{2}$ levels via atmosphere-ocean-biosphere feedback cycles (Denton et al., 2010). Moreover, analysis of globally widespread paleoclimate datasets indicates that the temperature conditions at the Earth's surface are also driven by solar insolation, particularly during glacial cycles (Denton et al., 2010). Although this forcing may have lag times, the changes in temperature recorded in the NGRIP $\delta^{18} \mathrm{O}$ temperature proxy (Rasmussen et al., 2006), Devil's Hole $\delta^{18} \mathrm{O}$ temperature proxy (Winograd et al., 2006) and alkenone Sea Surface Temperature (SST) records (Liu et al., 2005) indicate that the Northern Hemisphere temperatures during the periods before, during and after the LGM follow winter insolation (Figure 10 (a), (c), (d) and (f)). Additionally, new soil records calculating changes in precipitation minus evapotranspiration (P-ET), or soil infiltration rates (Maher et al., in prep) indicate that moisture availability appeared to synchronously peak in the Great Basin and Mojave deserts before the Last Glacial Maximum (Figure 10 (e)), preceding most of the lake record highstands (Table 6) by 8-10 kyr. This suggests that if the Northern Hemisphere westerlies mirrored the Southern Hemisphere westerlies, shifting poleward from 19 to 17 ka (mirroring ice sheet volume), then North America lake highstand peaks, occurring during and after this time period, cannot be solely explained by the passing westerlies hypothesis (Benson et al., 1990; Negrini, 2002). Thus, colder temperatures and decreased summer solar insolation following the LGM may have resulted in the lake highstands, rather than large increases in precipitation. 

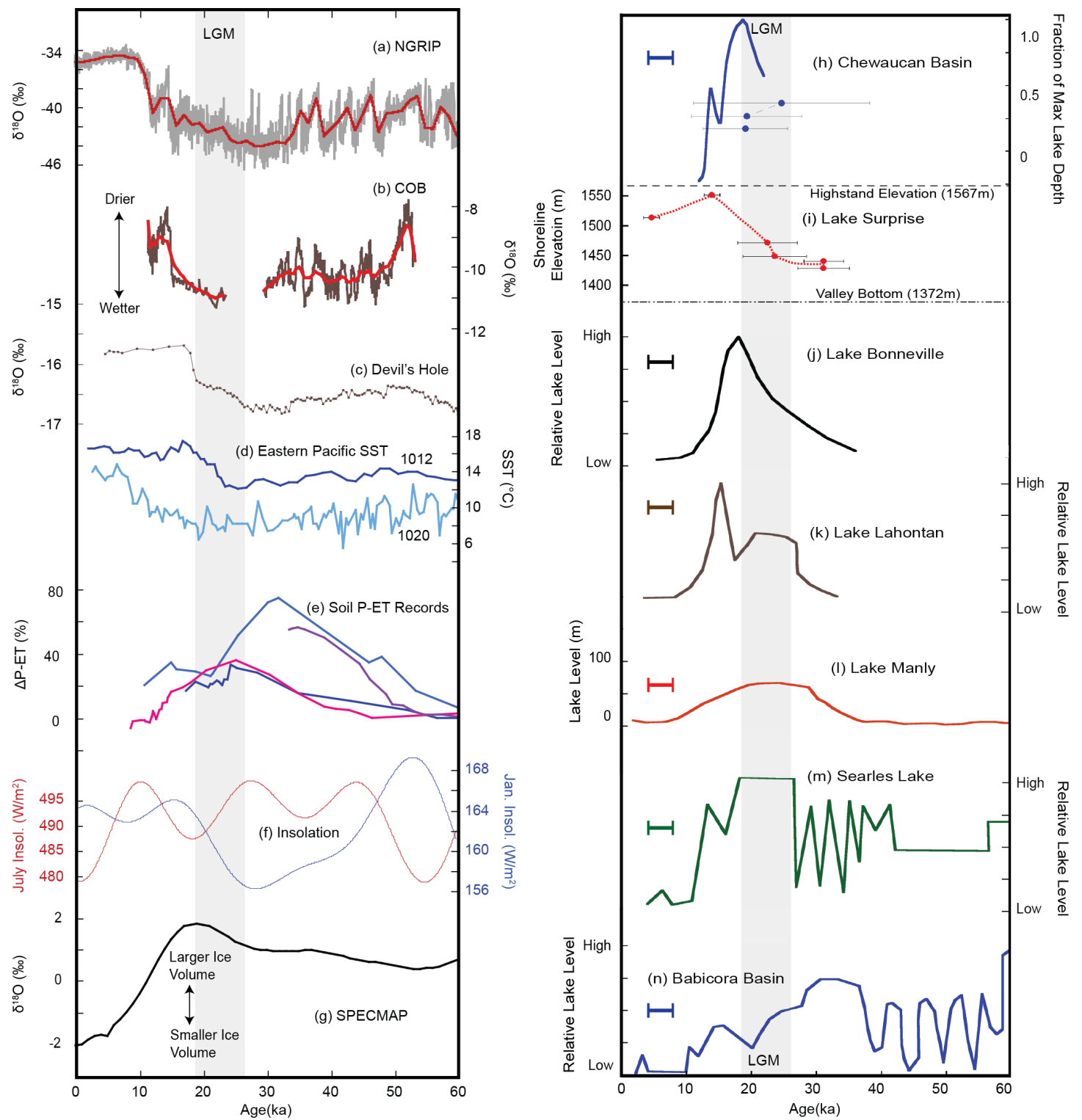

Figure 10. Compilation of Regional Western North America Paleoclimate Records. Comparison of multiple paleoclimate records and proxies with published lake level curves from the Basin and Range and the Lake Surprise lake level curve produced as part of this study. Lake level curves (right panel) are arranged approximately north to south. (a) NGRIP Greenland ice core $\delta^{18} \mathrm{O}$ on extended GICC05 timescale (Rasmussen et al., 2006), red line is smoothed at $1 \%$; (b) $\delta^{18} \mathrm{O}$ from Cave of the Bells (Wagner et al., 2010); (c) vein calcite $\delta^{18} \mathrm{O}$ from Devils Hole, Nevada (Winograd et al., 2006); (d) Alkenone SST proxy from Ocean Drilling Program sites 1012 (Liu et al., 2005) and 2020 (Liu, 2004); (e) reconstructed relative $\Delta$ P-ET (\%) from Maher et al., (in prep) pink, Newark Valley; dark blue, Diamond Valley; light blue, Fish Lake Valley; purple, Yucca Mountain. (f) January and July insolation for $40^{\circ} \mathrm{N}$ calculated using the program of (Laskar et al., 2004); (g) SPECMAP $\delta^{18} \mathrm{O}$ record (Martinson et al., 1987); (h) Chewaucan Basin relative lake level curve from sediment cores (Licciardi, 2001) and ${ }^{230} \mathrm{Th}-\mathrm{U}$ dated tufa samples (this study); (i) Lake Surprise lake level fluctuations from ${ }^{230} \mathrm{Th}-\mathrm{U}$ dated tufa samples (this study), BSE detrital corrected ages only; (j) and (k) Lake Lahontan, NV and Lake Bonneville, UT relative lake levels (Compiled by Brook et al., 2006, from McCoy, 1987; Oviatt et al., 1987; Benson et al., 1990; Oviatt et al., 1992); (e) Lake Manly, CA lake level (m) (Ku et al., 1998); (f) Searles Lake, CA relative lake level (Smith, 1984); (i) Babicora Basin, Mexico relative lake level (Metcalfe et al., 2002). The radiocarbon dated lake level curves $((\mathrm{h}),(\mathrm{j}),(\mathrm{k}),(\mathrm{i}),(\mathrm{m})$ and $(\mathrm{n}))$ have substantial error and uncertainty due to the necessary ${ }^{14} \mathrm{C}$ dead carbon correction and the radiocarbon to calendar age conversion uncertainty, particularly after the LGM due to plateaus in the calibration curve. The average standard error in the lake level curves is 1 to 3 ka (error bars given on figure). 
The nature of paleoclimatic records make it fundamentally difficult to separate the effects of decreased temperatures versus increased precipitation using lake shoreline records (Reheis, 1999a). Modeling of the Estancia Basin lake system hydrology (highstands and stillstands listed in Table 6) concluded that rainfall might have doubled relative to modern values to produce large pluvial lakes (Menking et al., 2004). Conversely, pollen records from California suggest changes in precipitation of less than $50 \%$ (Lyle et al., 2010).

The best apparent explanation for post-LGM lake highstands such as Surprise Valley is that during a period of decreased summer insolation, lake levels increased due to decreased summer temperatures and reduced surface evaporation. Lake levels are primarily controlled by runoff within a lake's watershed and surface evaporation (Reheis, 1999a). While lakes are likely recording summer conditions (that of decreased temperature), speleothems, groundwater systems and soils appear to reflect winter temperature conditions. As a result, the apparent northward migration of pluvial maxima during the last deglaciation track the receding Laurentide and Cordilleran ice sheets, with highstands also occurring during this period due to a minima in summer insolation.

Thus, the direct link between south-shifted westerlies and ice sheet extent, while not necessarily at odds with this data synthesis, was not the primary control on lake levels. Instead, south-shifted westerlies may have been simply a contributing factor to increasing moisture availability during this period of pluvial events. Further work to quantify and model the watershed scale hydrologic processes (e.g. Menking et al., 2004), regional to global scale atmospheric connections that lead to increased moisture availability (e.g. Kim et al., 2006), and lake evaporation fluxes (e.g. Gibson and Edwards, 2002) would help to clarify the fundamental question of whether decreased temperature or increased precipitation contributed to the expansive pluvial systems observed in the lake records during the period of the last deglaciation. 


\subsection{Global Climate Models and Paleoclimate Records}

In addition to providing a predictive tool for future climate scenarios due to anthropogenic $\mathrm{CO}_{2}$ emissions, climate models can also be used to evaluate hypotheses for Earth's past climate. This includes an assessment of the variability of the mid-latitude jet stream over North America that may have brought moisture to the now arid Basin and Range. Early modeling results focused on the late Pleistocene suggest that during the LGM both precipitation and westerly winds were enhanced over North America due to a stronger Aleutian Low over the Northeast Pacific Ocean (Kutzbach et al., 1988). Additionally, more recent modeling has shown that ice sheet extent, both continental ice sheets and sea ice, influence the strength and position of westerly storm tracks (Bromwhich et al., 2004; Sewall and Sloan, 2004). Conversely, paleoclimate proxies, such as P-ET from uranium isotopes in soil minerals (Maher et al., in prep) or sea surface temperature (SST) from alkenones in ocean sediment cores (as applied in Liu et al., (2005)), can be used to directly test the magnitude and direction of temporal changes predicted by the climate model outputs (Booth et al., 2006; Braconnot et al., 2012).

The Paleoclimate Model Intercomparison Project 2 (PMIP2) (Braconnot et al., 2007) has compiled a database of the results from published model simulations. Figure 11 shows the LGM anomaly (LGM minus modern) for P-ET, precipitation, mean annual wind vectors and zonal wind speed at both 200 millibar and 850 millibar from the Hadley Center Coupled Model, version 3 (HadCM3) run for the LGM and pre-industrial conditions (Gordon et al., 2000). This model is one of many used in the past and current rounds of Intergovernmental Panel on Climate Change (IPCC) assessment reports (Solomon et al., 2007; Braconnot et al., 2007). All parameters were imported as model outputs except for evaporation. The evaporation parameter required calculation, using the relationship between the latent heat flux (a model output) and the mass of water evaporated.

The LGM anomaly maps in Figure 11 demonstrate that HadCM3 does predict southward shifted wind patterns during the LGM, particularly in the upper (the 200 millibar) atmosphere level (Panels B and D). For Surprise Valley, the model predicts approximately double the rainfall amount (Figure 11A, $\sim 500 \mathrm{~mm} / \mathrm{yr}$ increase with a modern average of $566 \mathrm{~mm} / \mathrm{yr}$ (Table A1)). However, P-ET (Figure 11B) predicted by HadCM3 is at least two orders of magnitude greater than those predicted by the uranium isotope soil infiltration proxy (Figure $10(\mathrm{e}))$. 

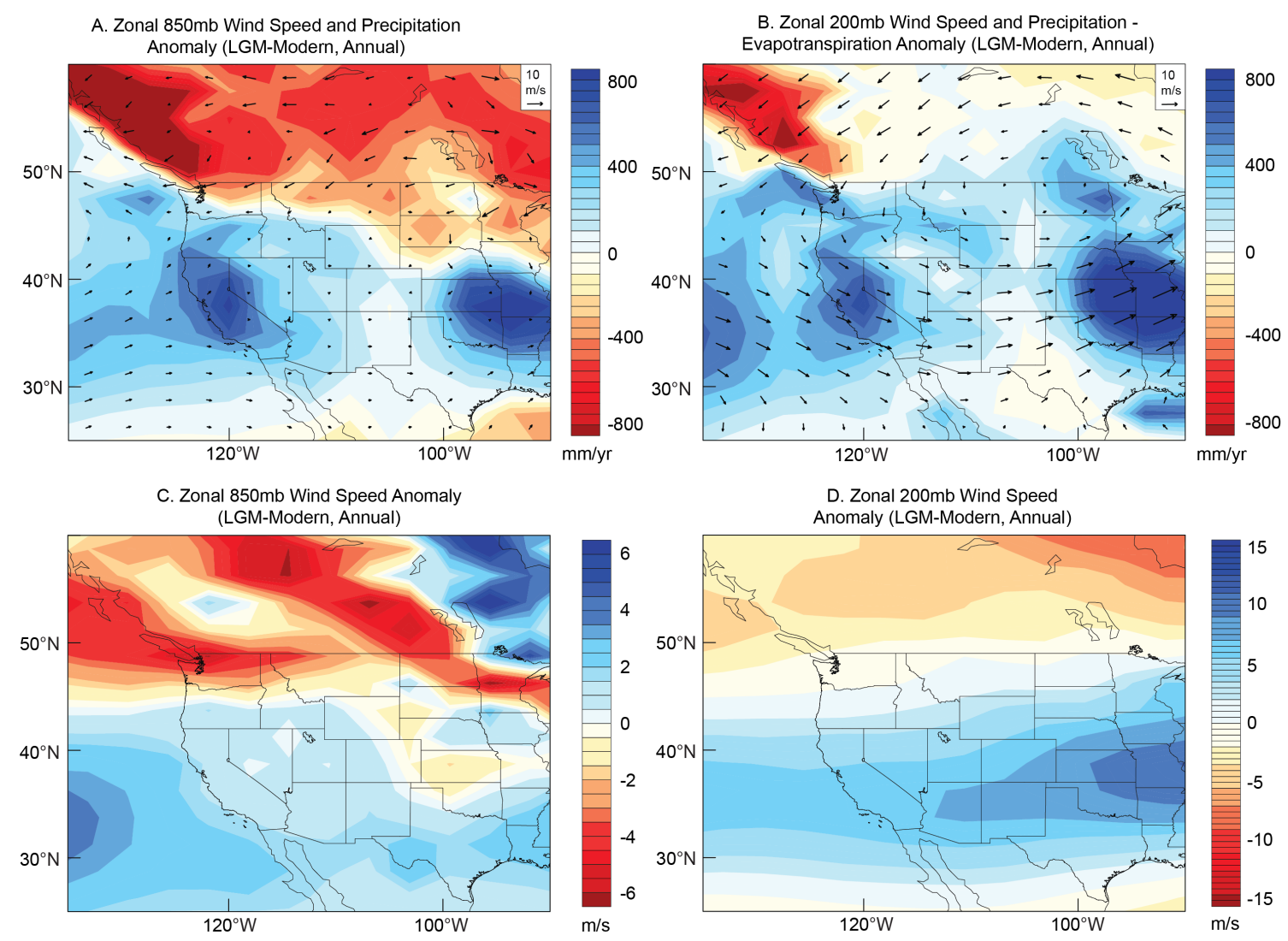

Figure 11. LGM Anomaly Maps for HadCM3 - 200 and 850 millibar Winds (m/s), Precipitation ( $\mathbf{m m} / \mathbf{y r}$ ) and Precipitation Minus Evapotranspiration (mm/yr). HadCM3 is an AOGCM coupling seaice, atmospheric and ocean parameters with an atmospheric grid resolution of $3.75^{\circ} \times 2.5^{\circ} \times 19$ vertical layers developed by the Hadley Centre in the United Kingdom. The HadCM3 modelling experiments, from ref. (Gordon et al., 2000) are available on the PMIP2 database (Braconnot et al., 2007;

http://pmip2.1sce.ipsl.fr/pmip2/). All maps are annually averaged anomaly maps, LGM minus modern.

The second set of LGM anomaly maps shown in Figure 12 illustrate additional climate parameters applicable to the paleoclimate records summarized in Figure 10. Analysis of total cloud cover data from HadCM3 demonstrate that cloud cover over the Basin and Range was $\sim 20 \%$ greater during the LGM (Figure 12A), indicating increased humidity and a net increase in albedo. While we cannot directly measure past cloud cover, this increase over the Basin and Range is consistent with moisture requirements needed to sustain pluvial lakes during the LGM.

HadCM3 predicts 0 to $200 \mathrm{~mm} / \mathrm{yr}$ increase in evapotranspiration in the Basin and Range during the LGM (Figure 12B). In comparison, modern evaporation was calculated as $1178 \mathrm{~mm} / \mathrm{yr}$ (Table A1) using the Kimberly Penman procedure (Dockter, 2004). Additionally, it is expected that during the LGM evapotranspiration would decrease, not increase as predicted by this model. This discrepancy (both in direction and magnitude of change for evaporation) in effectively modeling evapotranspiration may explain why 
HadCM3 over-predicts P-ET predicted by orders of magnitude relative to $U$ isotopes in soils (Figure 12C and D). While HadCM3 does not directly output model evapotranspiration in the PMIP2 database, it does have a soil evaporation term.

Combined with precipitation, this term should be similar to the uranium isotope proxy illustrated in Figure 10 (e) (Maher et al., in prep).
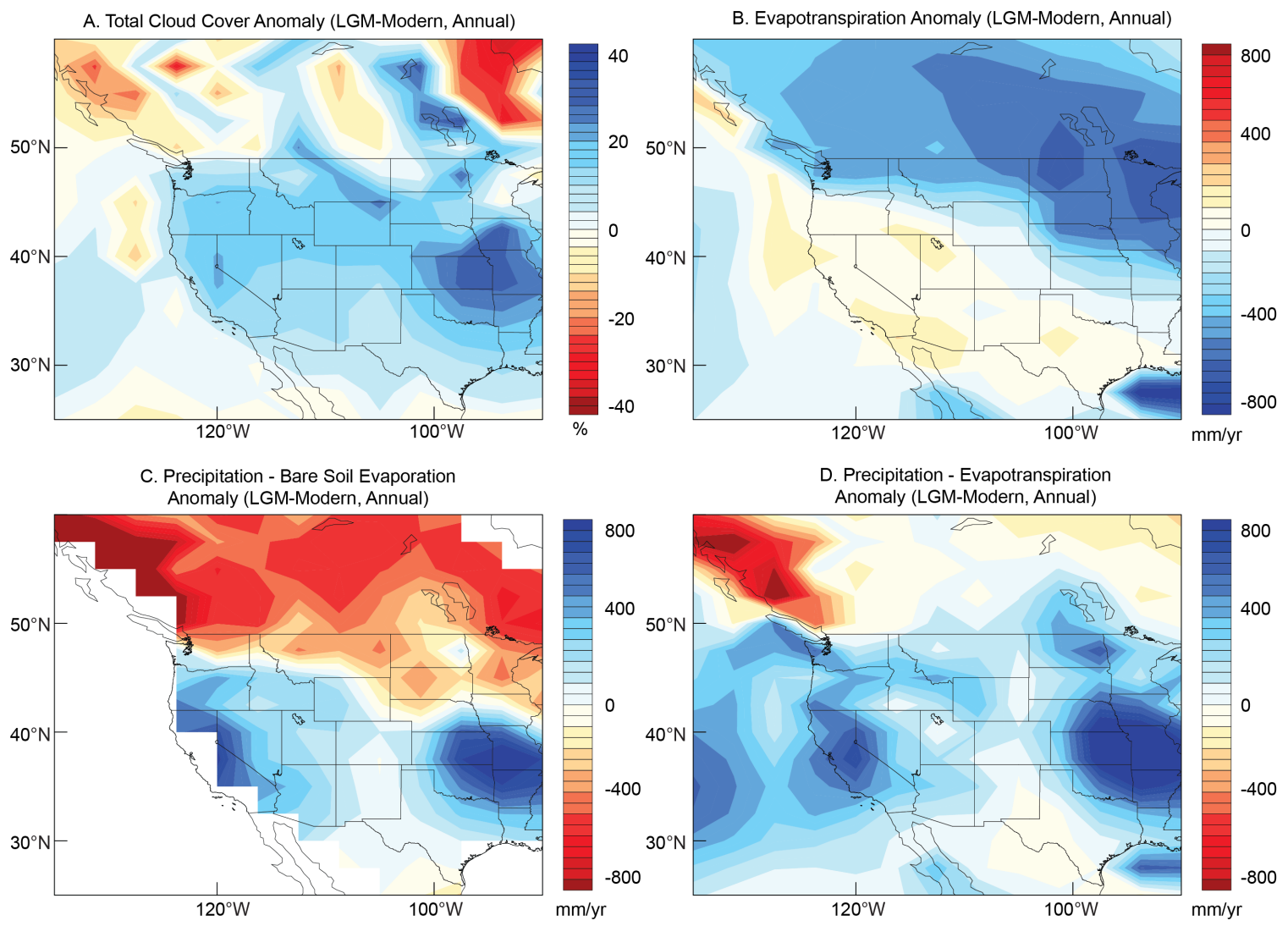

Figure 12. LGM Anomaly Maps for HadCM3 - (A) Total Cloud Cover (\%), (B) Evaporation (mm/yr), (C) Precipitation Minus Soil Evaporation (mm/yr) and (D) Precipitation Minus Evapotranspiration (mm/yr). For details on the HadCM3 AOGCM model see Figure 11.

The HadCM3 model does predict LGM temperatures accurately (Gordon et al., 2000; Braconnot et al., 2007), yet the parameterization of the hydrologic cycle over western North America (and likely in most of the model) clearly requires major refinement. This observation, a major discrepancy between the paleoclimate record and the paleoclimate model's hydrologic quantities, is similar to observations made by a more thorough assessment of the global water cycle in the PMIP2 models, the Climate Model Intercomparison Project (CMIP) 5 project, used in the IPCC Assessment Report 4 (Solomon et al., 2007) to assess future warming scenarios (Waliser et al., 2007). Analysis by Waliser et al., (2007) of historical data sets for precipitation, cloud water, precipitable 
water, runoff, soil moisture and snow mass indicate that while the current generation of models are predicting precipitation reasonably well at a global scale, the other remaining hydrologic quantities, particularly snow mass, runoff and soil moisture, remain highly variable among climate models. Furthermore, on a regional scale there exists a large discrepancy between the models (Waliser et al., 2003). Additional work is clearly necessary to improve AOGCMs' parameterization of the fundamental quantities relevant to the Earth's hydrologic balance. The newest suite of PMIP3/CMIP5 models, currently underway, will require mass balance between continental river runoff and precipitation (Taylor et al, 2012), previously not required in PMIP2/CMIP3 models. Improvements to quantify terrestrial components of the models to accurately track soil moisture, soil and lake evaporation, river runoff and groundwater recharge/discharge, will go a long way in producing AOGCMs with the predictive power to inform policy decisions in the future. 


\section{CONCLUSION}

Evaluating the conditions required to fundamentally change atmospherelithosphere-hydrosphere interactions during periods of Earth's past poses a challenge that necessitates the integration of geochemical, geochronologic and geophysical tools with numerical modeling approaches. To evaluate the factors that controlled pluvial lake systems in the Basin and Range during the LGM requires a spatially and temporally diverse set of paleoenvironmental/paleohydrologic data to infer paleoclimatic change. Often paleoclimate records rely on proxies requiring accurate calibration and modern analogs (e.g. Oster et al., in press; Maher et al., in prep). However, the approach taken in this study was more direct. Using materials found at specific shoreline elevations, the history of lake level fluctuation was evaluated at two study sites.

By dating shoreline elevations using tufa deposits I reconstructed past lake levels in Surprise Valley (Figure 9). Lake Surprise was moderately full (57 m deep, elevation of $1429 \mathrm{~m}$ to $1441 \mathrm{~m}$ ) during the last interglacial, beginning at least $31 \mathrm{ka}$, and increased in size between $31.17 \pm 3.06 \mathrm{ka}$ to $22.48 \pm 4.6 \mathrm{ka}$ ( $57 \mathrm{~m}$ to $100 \mathrm{~m}$ deep). Between $22.48 \pm$ $4.6 \mathrm{ka}$ and $13.93 \pm 1.21 \mathrm{ka}$, Lake Surprise nearly doubled in lake depth from $100 \mathrm{~m}$ to $180 \mathrm{~m}$ deep (up to an elevation of $1552 \mathrm{~m}$ ). The age from this shoreline is likely very close to the highstand age of latest Lake Surprise lake cycle. Samples analyzed from a shoreline at an elevation of $1514 \mathrm{~m}$ yielded a middle Holocene age of $4.64 \pm 1.22 \mathrm{ka}$, indicating that high lake levels at water depths of 140-180 m may have persisted from $13.93 \pm 1.21 \mathrm{ka}$, through the early Holocene until $4.64 \pm 1.22 \mathrm{ka}$.

In comparison, tufa samples from three elevations in the Chewaucan Basin yielded ages of $24.66 \pm 13.61 \mathrm{ka}, 19.28 \pm 8.53 \mathrm{ka}$, and $19.07 \pm 6.54 \mathrm{ka}$, all older than the previous ${ }^{14} \mathrm{C}$-dated highstand of $13.04 \mathrm{ka}$. These ages are likely associated with a previously unknown pluvial period occurring throughout much of MIS 2.

The Surprise Valley lake level curve precedes the existing Chewaucan Basin record (Licciardi, 2001; Negrini, 2002) to the north and follows the Lake Lahontan lake level record and highstand (Adams and Wesnousky, 1998) to the south.

The synthesis of existing paleoclimate records from western North America reveals an interesting interplay between key hydrologic quantities. The question of whether increased precipitation or decreased temperature provided the necessary available moisture to grow and sustain pluvial lakes remains an ongoing area of research, which can potentially be answered by the establishment of a more spatially extensive 
network of paleoclimate records. The diverse data analyzed here, consisting of lake records, soil infiltration records, speleothem records and temperature proxies (Figure 10), indicate that lake highstand ages, including Lake Surprise, primarily precede the LGM and lag behind peaks in soil infiltration by 8 to $10 \mathrm{kyr}$. Previously, the lake highstands were attributed to the passing of the westerly winds. However, inspection of insolation curves, temperature proxies and speleothems indicate that decreased summer insolation and temperature likely decreased summer evaporation, aiding the development of pluvial lake highstands.

Finally, hydrologic quantities from outputs of the HadCM3 AOGCM were used to evaluate challenges and uncertainties in the predictive power of AOGCMs. Most of the models used by the IPCC do appear to predict temperatures accurately in future global warming scenarios and in paleoclimate model simulations (Gordon et al., 2000; Braconnot et al., 2007). However, when categorically different forcings from the LGM are applied, the hydrological outputs appear to accurately predict the direction of change (in precipitation or P-ET), but over predict the magnitude of change over western North America.

This study illustrates some of the challenges associated with, and the importance of, producing paleoclimate records. The utility of paleoclimate data to decipher Earth's past climatic conditions relies on accurate geochronology and ${ }^{230} \mathrm{Th}-\mathrm{U}$ dating of materials, such as tufas, to yield absolute ages, allowing the correlation of climate proxies (Figure 10). Additionally, studies occurring during time intervals of abrupt climate change, such as the transitions from glacial to interglacial conditions following the LGM, may clarify the response of the climate system to large perturbations (e.g. Denton et al., 2010). Furthermore, the comparison between AOGCM simulations of the LGM and the paleoclimate data demonstrated that hydrologic quantities such as evapotranspiration, soil moisture and runoff will require additional paleoclimate proxy data to reduce the model uncertainty (Seager et al., 2007; Waliser et al., 2007) associated with the expected future hydrological changes in the arid western United States driven by global climate change. 


\section{APPENDICES}

\subsection{Map of Chewaucan Basin, OR}

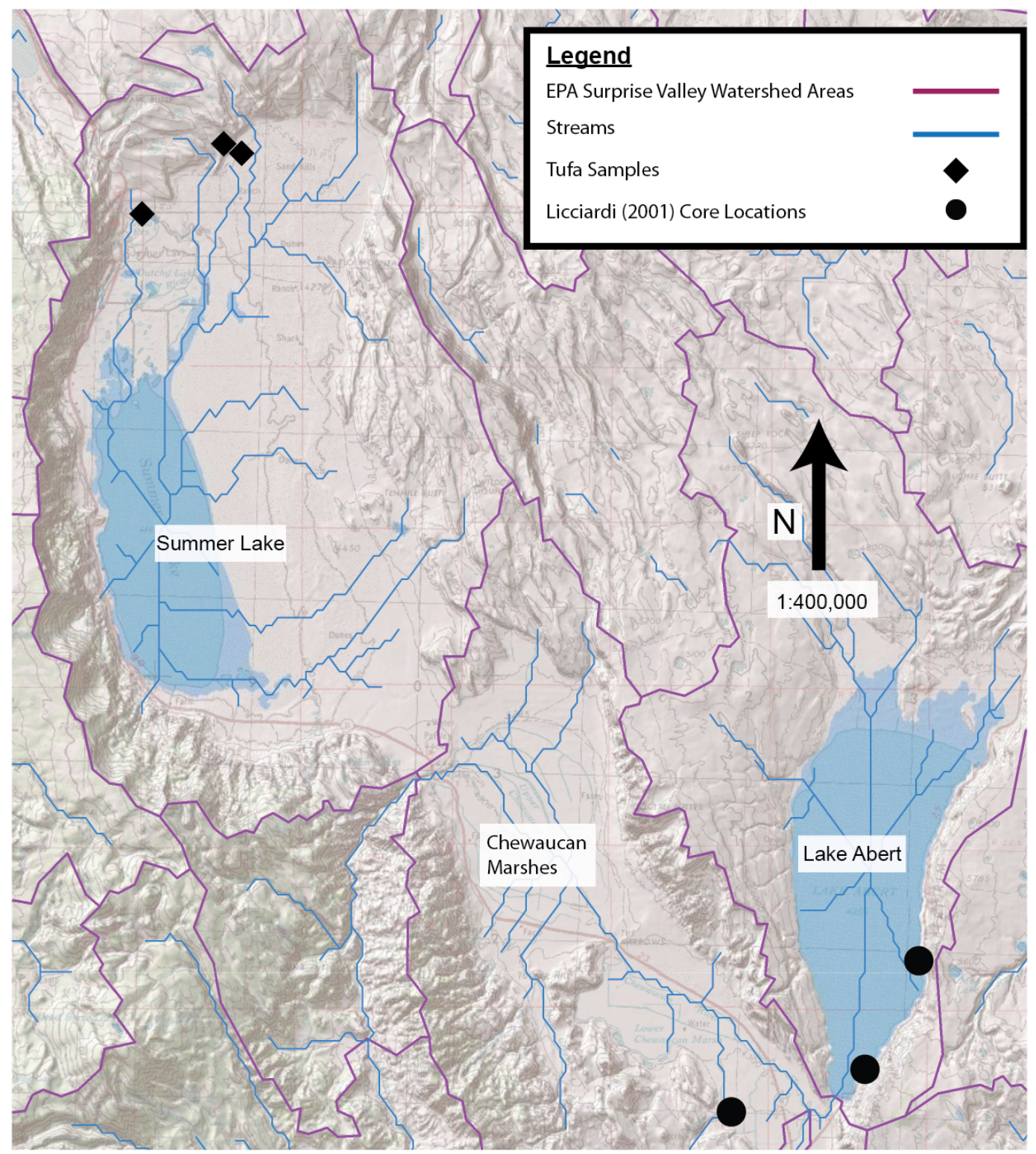

Figure A1. Map of Chewaucan Basin, Oregon Sample Collection Locations. Shaded relief map of the Chewaucan basin (1:400:000) with the Environmental Protection Agency (EPA) watersheds outlined in purple. The location of tufa samples used in this study and sediment cores used by Licciardi (2001) are denoted by black diamonds and black circles respectively. Map layers for watershed areas are established by the EPA (http://cfpub.epa.gov/surf/huc.cfm?huc code=18080001) and streams have been established by the USGS HydroSHEDS program (http://hydrosheds.cr.usgs.gov/). A shaded relief and USGS 100k topography map were used as the basemap. 


\subsection{Surprise Valley Watershed Statistics}

Table A1. Surprise Valley Watershed Climatic and Hydrologic Statistics Watershed size was calculated using ArcGIS layers from the EPA watershed layers. Lake depth and maximum lake size area were calculated by Reheis (1999b) and Clement (2005) intersected this data with regional Digital Elevation Models to calculated the maximum lake volume. Meteorological data from the WRCC (Western Regional Climate Center) is a historical dataset spanning 1884-2011 from the Cedarville, Lake City and Fort Bidwell, CA weather stations. The meteorological data from AgriMet is compiled by the Pacific Northwest Cooperative Agricultural Weather Network database spanning 1985-2011.

\begin{tabular}{|c|c|c|}
\hline $\begin{array}{c}\text { Measured/Calculated } \\
\text { Hydrologic Parameters }\end{array}$ & Quantity & Source \\
\hline $\begin{array}{c}\text { Watershed size } \\
\text { Maximum lake depth } \\
\text { Maximum lake area } \\
\text { Lake Volume } \\
\end{array}$ & $\begin{array}{c}2,313 \mathrm{~km}^{2} \\
1567 \mathrm{~m}-1372 \mathrm{~m}=195 \mathrm{~m} \\
1,478 \mathrm{~km}^{2} \\
321 \mathrm{~km}^{2}\end{array}$ & $\begin{array}{l}\text { EPA Watershed Demarcation } \\
\text { Reheis (1999b) and this study } \\
\text { Reheis (1999b) } \\
\text { Clemenent (2005) }\end{array}$ \\
\hline $\begin{array}{c}\text { Annual Historical Climate } \\
\text { Data }\end{array}$ & Quantity & Source \\
\hline Rainfall Total & $56.58 \mathrm{~cm} / \mathrm{yr}$ & WRCC \\
\hline Pan Evaporation & $117.88 \mathrm{~cm} / \mathrm{yr}$ & AgriMet \\
\hline Evaporation Total & $140.12 \mathrm{~cm} / \mathrm{yr}$ & AgriMet \\
\hline Mean Temperature & $9.22{ }^{\circ} \mathrm{C}$ & WRCC \\
\hline Mean High Temperature & $16.85^{\circ} \mathrm{C}$ & WRCC \\
\hline Mean Low Temperature & $1.59^{\circ} \mathrm{C}$ & WRCC \\
\hline Mean Relative Humidity & $57.58 \%$ & AgriMet \\
\hline
\end{tabular}




\subsection{Spike Calibration}

The following tables and graphs are the measurements made over multiple analysis days to calibrate the mixed spike, StUTh1, containing ${ }^{229}$ Th and ${ }^{236} \mathrm{U}$. All of the dilutions were carried out gravimetrically, weighing everything six times. CRM $145 \beta$ dilution has a ${ }^{238} \mathrm{U}$ concentration of $15870.4046 \mathrm{ng} / \mathrm{g}$ and Th Ames Metal $\beta$-dilution has a ${ }^{232} \mathrm{Th}$ concentration of $924.8870 \mathrm{ng} / \mathrm{g}$. Both standards were spiked with StUTh1 and diluted to concentrations suitable for MC-ICP-MS analysis. This calibration measured on the same aliquot of spike used to spike the tufa samples, locking in the ${ }^{230} \mathrm{Th} /{ }^{238} \mathrm{U}$ ratio prior to sample dissolution, elemental separation and analytical isotope measurement.

Table A2. Calibrated ${ }^{236}$ U Concentration in StUTh1 'Primary.' Errors include gravimetric and analytical errors. Isotopic standard CRM U010 was used to correct the ${ }^{236} \mathrm{U} /{ }^{238} \mathrm{U}$ ratios for Faraday/IC gain. The ${ }^{238} \mathrm{U}$ concentration of the spiked CRM145 was $15.7451 \mathrm{ng} / \mathrm{g}$. The concentration of ${ }^{236} \mathrm{U}$ was calculated using an error weighted average and was found to be $0.91987 \pm 0.00063 \mathrm{ng} / \mathrm{g}(2 \sigma, \mathrm{MSWD}=0.60, \mathrm{n}=18)$. These measurements are plotted graphically in Figure A2.

\begin{tabular}{|c|c|c|c|}
\hline \multirow[b]{2}{*}{ Date } & \multicolumn{3}{|c|}{${ }^{236} \mathbf{U}$ Concentration (ng/g) } \\
\hline & ${ }^{236} \mathbf{U} /{ }^{238} \mathbf{U}$ & & $2 \sigma(\%)$ \\
\hline May $9^{\text {th }} 2012^{1}$ & $5.912 \mathrm{E}-05 \pm 1.6 \mathrm{E}-07$ & $0.9177 \pm 0.0024$ & 0.264 \\
\hline May $9^{\text {th }} 2012^{1}$ & $5.904 \mathrm{E}-05 \pm 1.5 \mathrm{E}-07$ & $0.9164 \pm 0.0024$ & 0.261 \\
\hline May $9^{\text {th }} 2012^{1}$ & $5.871 \mathrm{E}-05 \pm 1.5 \mathrm{E}-07$ & $0.9114 \pm 0.0023$ & 0.253 \\
\hline May $9^{\text {th }} 2012^{1}$ & $5.884 \mathrm{E}-05 \pm 1.5 \mathrm{E}-07$ & $0.9133 \pm 0.0023$ & 0.252 \\
\hline May $9^{\text {th }} 2012^{1}$ & $5.885 \mathrm{E}-05 \pm 1.5 \mathrm{E}-07$ & $0.9135 \pm 0.0023$ & 0.256 \\
\hline May $9^{\text {th }} 2012^{1}$ & $5.894 \mathrm{E}-05 \pm 1.5 \mathrm{E}-07$ & $0.9148 \pm 0.0023$ & 0.250 \\
\hline May $14^{\text {th }} 2012$ & $5.926 \mathrm{E}-05 \pm 2.0 \mathrm{E}-07$ & $0.9198 \pm 0.0031$ & 0.337 \\
\hline May $14^{\text {th }} 2012$ & $5.917 \mathrm{E}-05 \pm 1.9 \mathrm{E}-07$ & $0.9185 \pm 0.0030$ & 0.330 \\
\hline May $14^{\text {th }} 2012$ & $5.924 \mathrm{E}-05 \pm 1.5 \mathrm{E}-07$ & $0.9196 \pm 0.0024$ & 0.257 \\
\hline May $14^{\text {th }} 2012$ & $5.924 \mathrm{E}-05 \pm 1.5 \mathrm{E}-07$ & $0.9195 \pm 0.0024$ & 0.257 \\
\hline May $14^{\text {th }} 2012$ & $5.922 \mathrm{E}-05 \pm 1.5 \mathrm{E}-07$ & $0.9193 \pm 0.0023$ & 0.249 \\
\hline May $14^{\text {th }} 2012$ & $5.922 \mathrm{E}-05 \pm 1.5 \mathrm{E}-07$ & $0.9192 \pm 0.0023$ & 0.255 \\
\hline May $16^{\text {th }} 2012$ & $5.917 \mathrm{E}-05 \pm 1.6 \mathrm{E}-07$ & $0.9184 \pm 0.0025$ & 0.273 \\
\hline May $16^{\text {th }} 2012$ & $5.916 \mathrm{E}-05 \pm 1.8 \mathrm{E}-07$ & $0.9183 \pm 0.0028$ & 0.304 \\
\hline May $16^{\text {th }} 2012$ & $5.927 \mathrm{E}-05 \pm 1.8 \mathrm{E}-07$ & $0.9201 \pm 0.0028$ & 0.305 \\
\hline May $16^{\text {th }} 2012$ & $5.934 \mathrm{E}-05 \pm 1.8 \mathrm{E}-07$ & $0.9211 \pm 0.0028$ & 0.304 \\
\hline May $16^{\text {th }} 2012$ & $5.917 \mathrm{E}-05 \pm 1.9 \mathrm{E}-07$ & $0.9185 \pm 0.0030$ & 0.323 \\
\hline May $16^{\text {th }} 2012^{2}$ & $5.898 \mathrm{E}-05 \pm 1.8 \mathrm{E}-07$ & $0.9155 \pm 0.0029$ & 0.313 \\
\hline May $16^{\text {th }} 2012$ & $5.931 \mathrm{E}-05 \pm 1.8 \mathrm{E}-07$ & $0.9207 \pm 0.0028$ & 0.306 \\
\hline May $16^{\text {th }} 2012$ & $5.935 \mathrm{E}-05 \pm 1.8 \mathrm{E}-07$ & $0.9212 \pm 0.0028$ & 0.306 \\
\hline May $16^{\text {th }} 2012$ & $5.934 \mathrm{E}-05 \pm 1.8 \mathrm{E}-07$ & $0.9211 \pm 0.0028$ & 0.304 \\
\hline May $16^{\text {th }} 2012$ & $5.933 \mathrm{E}-05 \pm 1.8 \mathrm{E}-07$ & $0.9210 \pm 0.0028$ & 0.300 \\
\hline May $16^{\text {th }} 2012$ & $5.934 \mathrm{E}-05 \pm 1.8 \mathrm{E}-07$ & $0.9211 \pm 0.0028$ & 0.305 \\
\hline May $16^{\text {th }} 2012$ & $5.935 \mathrm{E}-05 \pm 1.8 \mathrm{E}-07$ & $0.9213 \pm 0.0028$ & 0.305 \\
\hline May $16^{\text {th }} 2012$ & $5.926 \mathrm{E}-05 \pm 1.8 \mathrm{E}-07$ & $0.9199 \pm 0.0029$ & 0.312 \\
\hline
\end{tabular}

${ }^{1}$ Spike-standard equilibration appeared to be occurring during this first day of analysis (May $9^{\text {th }} 2012$ ) after the solution was made (Figure A2, Panel A), these measurements were discarded from final weighted average (See Figure A2).

${ }^{2}$ Observed a mass bias correction issue, caused raw ${ }^{236} \mathrm{U} /{ }^{238} \mathrm{U}$ value of the solution and ${ }^{235} \mathrm{U} /{ }^{238} \mathrm{U}$ value of CRM U010 brackets to fall outside the range of standard error for the day's analysis, this measurement was discarded from final weighted average. 


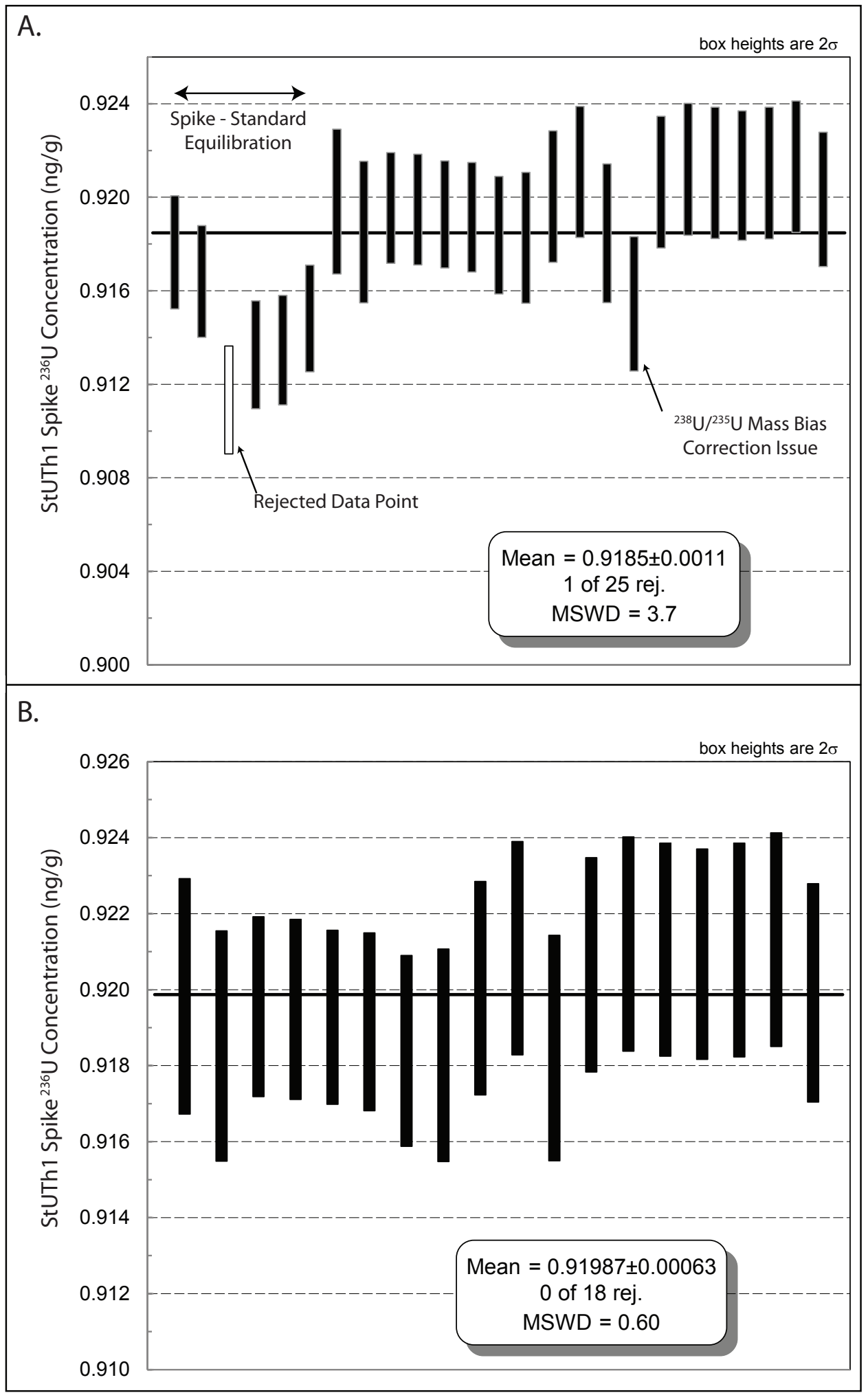

Figure A2. ${ }^{236} \mathrm{U}$ concentration calibration in StUTh1 spike. The horizontal black lines are the error weighted average concentration. 32 measurements were made on the spiked CRM 145 solution during three analytical sessions. (a) The first analytical day was discarded, there appeared to be spike-sample equilibrations problems. On that analytical day CRM 145 was spike at the beginning of the day. (b) Summary of just the measurements used to calculated the error weighted mean concentration. Graph and calculations were made using Isoplot (Ludwig, 2003a,b). 
Table A3. Calibrated ${ }^{229}$ Th Concentration in StUTh1. Errors include gravimetric and analytical errors. Isotopic standard IRMM35 was used to correct the ${ }^{229} \mathrm{Th} /{ }^{230} \mathrm{Th}$ ratios for Faraday/IC gain. The ${ }^{232} \mathrm{Th}$ concentration of the spiked Th Ames Metal was $41.4855 \mathrm{ng} / \mathrm{g}$. The concentration of ${ }^{229} \mathrm{Th}$ was calculated using an error weighted average and was found to be $0.22418 \pm 0.00058 \mathrm{ng} / \mathrm{g}(2 \sigma, \mathrm{MSWD}=0.89, \mathrm{n}=32)$. These measurements are plotted graphically in figure A3.

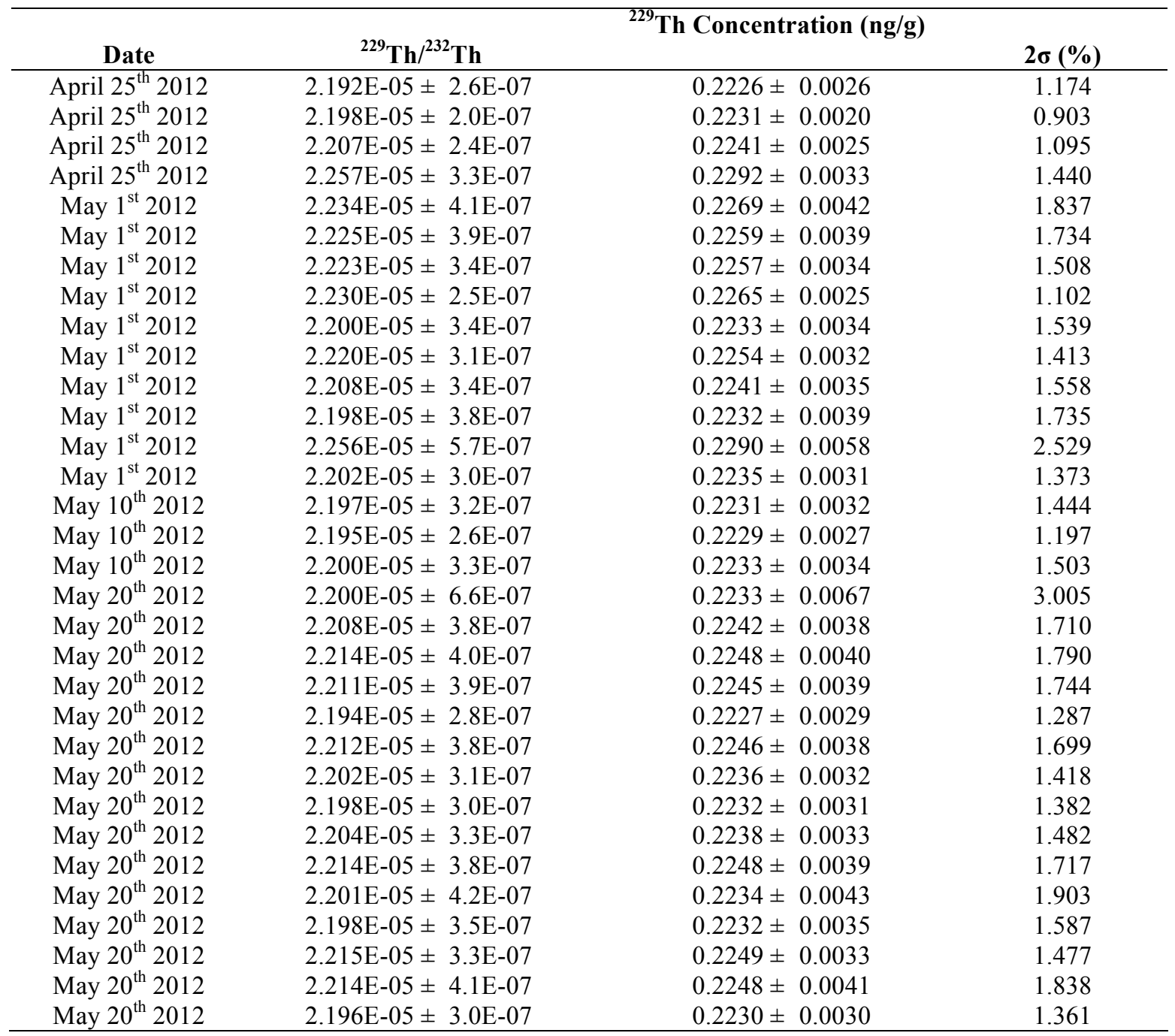




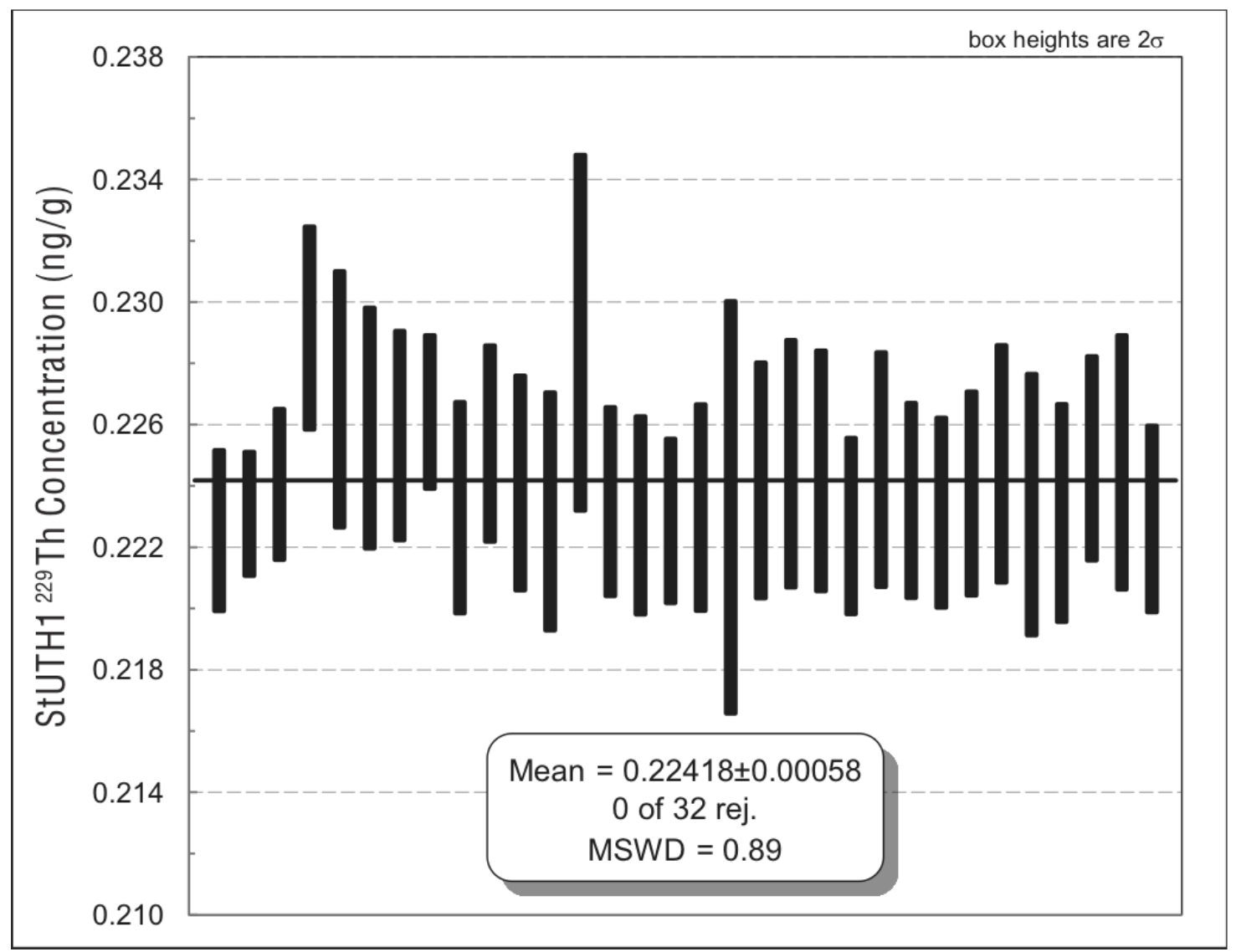

Figure A3. ${ }^{236}$ Th concentration calibration in StUTh1. The horizontal black line is the error weighted average. 32 measurements were made on the spiked Th Ames Metal solution during four analytical sessions. Graph and calculations were made using Isoplot (Ludwig, 2003a,b).

\subsection{Column Chemistry Modified Recipe}

Table A4. Column Chemistry Procedure for separation of Th and U. This recipe was originally developed by Luo et al, (1997).

\begin{tabular}{lll}
\hline Step & Details & Eluted \\
\hline Resin & $0.25 \mathrm{~mL} \mathrm{TRU-Spec} \mathrm{Resin} \mathrm{200-400} \mathrm{mesh}$ & \\
Cleaning & $2 \times 1.25 \mathrm{~mL} 0.2 \mathrm{M} \mathrm{HCl}$ & \\
& $2 \times 1.25 \mathrm{~mL} 0.1 \mathrm{M} \mathrm{HCl}-0.3 \mathrm{M} \mathrm{HF}$ & \\
Conditioning & $1 \mathrm{~mL} 7 \mathrm{M} \mathrm{HNO}_{3}$ & \\
Loading Sample & 1 to $4 \mathrm{~mL} \mathrm{M} \mathrm{HNO}_{3}$ & Major Elements \\
Wash & $4 \times 1 \mathrm{~mL} \mathrm{HNO} \mathrm{HN}_{3}$ & Rare Earth Elements \\
& $2 \times 1 \mathrm{~mL} 3 \mathrm{M} \mathrm{HCl}$ & Thorium \\
Collection & $2 \times 1 \mathrm{~mL} 0.2 \mathrm{M} \mathrm{HCl}$ & Uranium \\
& $2 \times 1 \mathrm{~mL} 0.1 \mathrm{M} \mathrm{HCl}-0.3 \mathrm{M} \mathrm{HF}$ & Uranium \\
& $1 \times 1 \mathrm{~mL} 0.6 \mathrm{M} \mathrm{HF}$ & \\
\hline
\end{tabular}




\subsection{Explanation of the Detrital Thorium Age Correction Methods}

Below is a derivation of the Total Sample Dissolution (TSD) detrital correction method (cf. Ku, 2000). Equations 2 and 4 describe the linear least squares regression (unweighted as suggested by $\mathrm{Ku}(2000)$ ). The derived equations 3 and 5 below are the slopes, corresponding to the detrital corrected activity ratios. Equations 4 and 7 are the $y$ intercepts, given a constant y intercept for both equations the linearity is expected of the $\left({ }^{234} \mathrm{U} /{ }^{232} \mathrm{Th}\right)$ vs. $\left({ }^{230} \mathrm{Th} /{ }^{232} \mathrm{Th}\right)$ and $\left({ }^{238} \mathrm{U} /{ }^{232} \mathrm{Th}\right)$ vs. $\left({ }^{230} \mathrm{Th} /{ }^{232} \mathrm{Th}\right)$ plots.

$\frac{{ }^{230} \mathrm{Th}}{{ }^{232} \mathrm{Th}}=U \frac{{ }^{234} \mathrm{U}}{{ }^{232} \mathrm{Th}}+E$

$U=\left(\frac{{ }^{230} \mathrm{Th}^{*}}{{ }^{234} \mathrm{U}}\right)_{\text {authigenic }}$

$E=\left(\frac{{ }^{230} \mathrm{Th}}{{ }^{232} \mathrm{Th}}\right)_{0} e^{-\lambda_{0} t}+\left(\frac{{ }^{234} \mathrm{U}}{{ }^{232} \mathrm{Th}}\right)_{\text {detrital }}\left[\left(\frac{{ }^{230} \mathrm{Th}^{*}}{{ }^{234} \mathrm{U}}\right)_{\text {detrital }}-\left(\frac{{ }^{230} \mathrm{Th}^{*}}{{ }^{234} \mathrm{U}}\right)_{\text {authigenic }}\right]$

$\frac{{ }^{234} \mathrm{U}}{{ }^{232} \mathrm{Th}}=W \frac{{ }^{238} \mathrm{U}}{{ }^{232} \mathrm{Th}}+F$

$W=\left(\frac{{ }^{234} \mathrm{U}}{{ }^{238} \mathrm{U}}\right)_{\text {authigenic }}$

$F=\left(\frac{{ }^{238} \mathrm{U}}{{ }^{232} \mathrm{Th}}\right)_{\text {detrital }}\left[\left(\frac{{ }^{234} \mathrm{U}}{{ }^{238} \mathrm{U}}\right)_{\text {detrital }}-\left(\frac{{ }^{234} \mathrm{U}}{{ }^{238} \mathrm{U}}\right)_{\text {authigenic }}\right]$ 
The variables $U$ and $\mathrm{W}$ (equations 3 and 6) are the slopes of equations 2 and 5 , corresponding to the detrital corrected activity ratios $\left({ }^{230} \mathrm{Th} /{ }^{234} \mathrm{U}\right)$ and $\left({ }^{234} \mathrm{U} /{ }^{238} \mathrm{U}\right)$ used in the age equation (equation 1). E and $\mathrm{F}$ (equations 4 and 7) are the y-interecepts of equations 2 and 5 , corresponding to the detrital $\left({ }^{230} \mathrm{Th} /{ }^{232} \mathrm{Th}\right)$ and $\left({ }^{234} \mathrm{U} /{ }^{232} \mathrm{Th}\right)$ incorporated into the mineral at the time of mineral precipitation.

The second approach, Bulk Silicate Earth (BSE), detrital correction used by others is to assume that the sample's initial $\left({ }^{230} \mathrm{Th} /{ }^{232} \mathrm{Th}\right)\left({ }^{234} \mathrm{U} /{ }^{232} \mathrm{Th}\right)$ and $\left({ }^{238} \mathrm{Th} /{ }^{232} \mathrm{Th}\right)$ are equal to those of either (1) a second, measured and related sample, such as pure detritus, or (2) an assumed isotopic composition such as the average crustal ${ }^{232} \mathrm{Th} /{ }^{238} \mathrm{U}$ (Ludwig and Titterington, 1994). For this study, the latter method was applied and a correction was applied assuming a ${ }^{230} \mathrm{Th} /{ }^{232} \mathrm{Th}$ ratio equal to that of bulk silicate earth $\left(4.46 \times 10^{6} \pm 2.23\right.$ $(2 \sigma))$ and $\mathrm{a}^{232} \mathrm{Th} /{ }^{238} \mathrm{U}$ of $3.8 \pm 1.9(2 \sigma)$. The geochronology program Isoplot, developed at the Berkeley Geochronology Center (Ludwig, 2003a,b), has built in functions to calculate corrected ages based on this method.

\subsection{Elevation Transect Data Tables}

The following tables summarize the data collected by walking transects with handheld GPS. Eight transects (T-1 to 8) were carried out in total. See location of transects on map of study area (Figure 2B). "?? denotes duplicate surfaces observed at similar elevations.

Table A5. Transect 1

\begin{tabular}{ccc}
\hline Distance $(\mathrm{m})$ & Elevation $(\mathrm{m})$ & Shoreline No. \\
\hline 0.0 & 1415.0 & 1 \\
105.7 & 1428.6 & 2 \\
177.9 & 1439.1 & 3 \\
266.2 & 1451.5 & 4 \\
365.3 & 1457.9 & 5 \\
438.1 & 1470.0 & $6 ?$ \\
528.1 & 1474.4 & $6 ?$ \\
661.9 & 1491.1 & 7 \\
838.1 & 1513.2 & $8 ?$ \\
899.8 & 1513.8 & $8 ?$ \\
1011.4 & 1532.4 & 9 \\
1152.5 & 1552.2 & 10 \\
1207.4 & 1565.6 & 11 \\
\hline
\end{tabular}

Table A6. Transect 2

\begin{tabular}{ccc}
\hline Distance $(\mathrm{m})$ & Elevation $(\mathrm{m})$ & Shoreline No. \\
\hline 0.0 & 1422.5 & 1 \\
33.9 & 1425.4 & 2 \\
110.8 & 1440.3 & 3 \\
221.5 & 1457.4 & 4 \\
299.1 & 1470.7 & 6 \\
\hline
\end{tabular}


Table A7. Transect 3

\begin{tabular}{ccc}
\hline Distance $(\mathrm{m})$ & Elevation $(\mathrm{m})$ & Shoreline No. \\
\hline 0.0 & 1425.4 & $2 ?$ \\
79.4 & 1432.8 & $2 ?$ \\
238.9 & 1438.6 & 3 \\
346.2 & 1447.0 & 4 \\
430.0 & 1458.4 & 5 \\
\hline Table A8. Transect 4 & & \\
\hline Distance $(\mathrm{m})$ & Elevation $(\mathrm{m})$ & Shoreline No. \\
\hline 0.0 & 1440.5 & 3 \\
90.1 & 1447.7 & 4 \\
190.5 & 1448.7 & 4 \\
376.1 & 1457.8 & 5 \\
\hline
\end{tabular}

Table A9. Transect 5

\begin{tabular}{ccc}
\hline Distance $(\mathrm{m})$ & Elevation $(\mathrm{m})$ & Shoreline No. \\
\hline 0.0 & 1417.4 & 1 \\
105.1 & 1428.6 & $2 ?$ \\
135.7 & 1433.3 & $2 ?$ \\
200.8 & 1446.7 & 4 \\
284.1 & 1461.0 & 5 \\
340.7 & 1472.5 & 6 \\
\hline
\end{tabular}

Table A10. Transect 6

\begin{tabular}{ccc}
\hline Distance $(\mathrm{m})$ & Elevation $(\mathrm{m})$ & Shoreline No. \\
\hline 0.0 & 1493.8 & 7 \\
418.3 & 1515.3 & 8 \\
491.6 & 1520.8 & $?$ \\
592.9 & 1528.2 & 9 \\
\hline
\end{tabular}

Table A11. Transect 7

\begin{tabular}{ccc}
\hline Distance $(\mathrm{m})$ & Elevation $(\mathrm{m})$ & Shoreline No. \\
\hline 0.0 & 1408.6 & Below 1 \\
234.2 & 1419.7 & 1 \\
457.4 & 1431.3 & 2 \\
580.2 & 1441.5 & 3 \\
696.8 & 1450.6 & 4 \\
800.7 & 1460.8 & 5 \\
869.6 & 1468.4 & $6 ?$ \\
896.5 & 1472.9 & $6 ?$ \\
\hline
\end{tabular}

Table A12. Transect 8

\begin{tabular}{ccc}
\hline Distance $(\mathrm{m})$ & Elevation $(\mathrm{m})$ & Shoreline No. \\
\hline 0.0 & 1402.9 & Below 1 \\
265.3 & 1410.9 & Below 1 \\
467.8 & 1416.6 & 1 \\
701.6 & 1428.8 & 2 \\
829.2 & 1434.9 & $?$ \\
963.5 & 1443.3 & 3 \\
\hline
\end{tabular}




\section{WORKS CITED}

Adams, K.D. and Wesnousky, S.G. (1998). Shoreline processes and the age of the Lake Lahontan highstand in the Jessup embayment, Nevada. Geological Society of America Bulletin, 110(10), 1318. Geological Society of America.

Adams, K.D., Wesnousky, S.G. and Bills, B.G. (1999). Isostatic rebound, active faulting, and potential geomorphic effects in the Lake Lahontan basin, Nevada and California. Geological Society of America Bulletin, 111(12), 1739-1756.

Allen, B.D. and Anderson, R.Y. (2000). A continuous, high-resolution record of late Pleistocene climate variability from the Estancia basin, New Mexico. Geological Society of America Bulletin, 112(9), 1444. Geological Society America.

Amundson, R., Chadwick, O., Kendall, C., Wang, Y. and DeNiro, M. (1996). Isotopic evidence for shifts in atmospheric circulation patterns during the late Quaternary in mid-North America. Geology, 24(1), 23.

Asmerom, Y., Polyak, V.J. and Burns, S.J. (2010). Variable winter moisture in the southwestern United States linked to rapid glacial climate shifts. Nature Geoscience, 3(2), 114-117. doi:10.1038/ngeo754

Anderson, P. M., Barnosky, C. W., Bartlein, P. J., Behling, P. J., Brubaker, L., Cushing, E. J., et al. (1988). Climatic changes of the last 18,000 years: Observations and model simulations. Science, 241(4869), 1043-1052.

Anderson, Roger Y, Allen, B.D. and Menking, K.M. (2002). Geomorphic Expression of Abrupt Climate Change in Southwestern North America at the Glacial Termination. Quaternary Research, 57(3), 371-381.

Ballenger, J.A.M., Holliday, V.T., Kowler, A.L., Reitze, W.T., Prasciunas, M.M., Shane, Miller, D. and Windingstad, J.D. (2011). Evidence for Younger Dryas global climate oscillation and human response in the American Southwest. Quaternary International, 242(2), 502-519.

Barnett, T.P., Pierce, D.W., Hidalgo, H.G., Bonfils, C., Santer, B.D., Das, T., Bala, G., et al. (2008). Human-induced changes in the hydrology of the western United States. Science, 319(5866), 1080-3.

Barnett, T. P., Adam, J. C., \& Lettenmaier, D. P. (2005). Potential impacts of a warming climate on water availability in snow-dominated regions. Nature, 438(7066), 303-309.

Benson, L.V. (2003). Western lakes. Developments in Quaternary Science, 1(1965), 185-204.

Benson, L.V., Currey, D.R., Dorn, R.I., Lajoie, K.R., Oviatt, C.G., Robinson, S.W., Smith, G.I., et al. (1990). Chronology of expansion and contraction of four great Basin lake systems during the past 35,000 years. Palaeogeography, Palaeoclimatology, Palaeoecology, 78(3-4), 241-286.

Benson, L.V., Lund, S.P., Burdett, J.W., Kashgarian, M., Rose, T.P., Smoot, J.P. and Schwartz, M. (1998). Correlation of Late-Pleistocene Lake-Level Oscillations in Mono Lake, California, with North Atlantic Climate Events. Quaternary Research, 49(1), 1-10.

Bills, B.G. and May, G.M. (1987), Lake Bonneville; Constraints on Lithospheric Thickness and Upper Mantle Viscosity From Isostatic Warping of Bonneville, Provo, and Gilbert Stage Shorelines, Journal of Geophysical Research, 92(B11), 11, 493-11,509.

Bischoff, J.L. and Fitzpatrick, A. (1990). U -series dating of impure carbonates : An isochron technique using total-sample dissolution. Geochimica et Cosmochimica Acta, 55, 543-554. 
Booth, R.K., Kutzbach, J.E., Hotchkiss, S.C. and Bryson, R.A. (2006). A reanalysis of the relationship between strong westerlies and precipitation in the Great Plains and Midwest regions of North America. Climatic Change, 76(3-4), 427-441.

Braconnot, P. and Otto-Bliesner, B. (2007). Results of PMIP2 coupled simulations of the Mid-Holocene and Last Glacial Maximum - Part 1 : experiments and large-scale features. Climate of the Past, 261277.

Braconnot, P., Harrison, S.P., Kageyama, M., Bartlein, P.J., Masson-Delmotte, V., Abe-Ouchi, A., OttoBliesner, B., et al. (2012). Evaluation of climate models using palaeoclimatic data. Nature Climate Change, (March), 1-8.

Bromwich, D.H., Toracinta, E.R., Wei, H.L., Oglesby, R.J., Fastook, J.L., Hughes, T.J. (2004). Polar MM5 simulations of the winter climate of the Laurentide Ice Sheet at the LGM. Journal of Climate, 17, 3415-3433.

Brook, G. A., Ellwood, B. B., Railsback, L. B., \& Cowart, J. B. (2006). A 164 ka record of environmental change in the American Southwest from a Carlsbad Cavern speleothem.Palaeogeography, Palaeoclimatology, Palaeoecology, 237(2-4), 483-507.

Clement, S. (2005). Modeling of the Great Basin pluvial lakes during the Last Glacial Maximum. Ph.D. Thesis. Kent State University.

Cohen, A., Palacios-Fest, M., Negrini, R., Wigand, P. and Erbes, D. (2000). A paleoclimate record for the past 250,000 years from Summer Lake, Oregon, USA: II. Sedimentology, paleontology and geochemistry. Journal of Paleolimnology, 24(2), 151-182.

Davis, S.J., Mix, H.T., Wiegand, B.A., Carroll, A.R. and Chamberlain, C.P. (2009). Synorogenic evolution of large-scale drainage patterns: Isotope paleohydrology of sequential Laramide basins. American Journal of Science, 309(7), 549-602.

Denniston, R.F., Asmerom, Y., Polyak, V., Dorale, J.A., Carpenter, S.J., Trodick, C., Hoye, B., et al. (2007). Synchronous millennial-scale climatic changes in the Great Basin and the North Atlantic during the last interglacial. Geology, 35(7), 619.

Denton, G.H., Anderson, R.F., Toggweiler, J.R., Edwards, R.L., Schaefer, J.M. and Putnam, A.E. (2010). The last glacial termination. Science, 328(5986), 1652-6.

Dockter, D. (1994), Computation of the 1982 Kimberly-Penman and the Jensen-Haise Evpotranspiration Equations a Applied in the US Burea of Reclamation's Pacific Northwest AgriMet Program. US Bureau of Reclamation, Pacific Northwest Region, Water Conservation Center. Version 2, Palmer, P. (revised 2008) Retrieved from: http://www.usbr.gov/pn/agrimet/

Edwards, R.L., Chen, J. H., Ku, T. L., Wasserburg, G. J., (1987). Precise timing of the last interglacial period from mass spectrometric determination of thorium-230 in corals. Science, 236, 1548-1553.

Egger, A.E. and Huerta, A. (2011). Personal communication on initial modeling of Surprise Valley isostatic rebound.

Egger, A.E. and Miller, E.L. (2011). Evolution of the northwestern margin of the Basin and Range: The geology and extensional history of the Warner Range and environs, northeastern California. Geosphere, 7(3), 756. Geological Society of America.

Egger, A.E., Glen, J.M.G. and Ponce, D.A. (2010). The northwestern margin of the Basin and Range province. Tectonophysics, 488(1-4), 150-161. 
Elder, D. and de la Fuente, J. (2009), Bidwell Landslide: Interplay of Landsliding with Active Faulting, Glaciation, Late-Pleistocene Pluvial Lakes and Hydrothermally-altered Tuffs. Portland, OR, Annual Meeting, Geological Society of America, 41, 7, 325.

Eugster, H.P. and Kelts, K. (1983) Lacustrine chemical sediments, in Goudie, A.S. and Pye, K., editors, Chemical sediments and geomorphology: precipitates and residual in the near-surface environment: San Francisco, Academic Press, 321-368.

Felton, A., Jewell, P.W., Chan, M. and Currey, D. (2006). Controls of Tufa Development in Pleistocene Lake Bonneville, Utah. The Journal of Geology, 114(3), 377-389.

Fletcher, K.E.K., Sharp, W.D., Kendrick, K.J., Behr, W.M., Hudnut, K.W., Hanks, T.C. (2010). Th-230/U dating of a late Pleistocene alluvial fan along the southern San Andreas fault. Geological Society of America Bulletin, 122, 1347-1359.

García, A.F., and Stokes, M. (2006). Late Pleistocene highstand and recession of a small, high-altitude pluvial lake, Jakes Valley, central Great Basin, USA. Quaternary Research, 65(1), 179-186.

Garnett, E.R., Gilmour, M.A., Rowe, P.J., Andrews, J.E. and Preece, R.C. (2004). 230Th/234U dating of Holocene tufas: possibilities and problems. Quaternary Science Reviews, 23(7-8), 947-958.

Gibson, J.J. and Edwards, T.W.D. (2002). Regional water balance trends and evaporation-transpiration partitioning from a stable isotope survey of lakes in northern Canada. Global Biogeochemical Cycles, 16(2).

Godsey, H.S., Oviatt, C.G., Miller, D.M. and Chan, M.A. (2011). Stratigraphy and chronology of offshore to nearshore deposits associated with the Provo shoreline, Pleistocene Lake Bonneville, Utah. Palaeogeography, Palaeoclimatology, Palaeoecology, 310(3-4), 442-450.

Gordon, C., Cooper, C., Senior, C. and Banks, H. (2000). The simulation of SST, sea ice extents and ocean heat transports in a version of the Hadley Centre coupled model without flux adjustments. Climate Dynamics, 16, 148-168.

Grigg, L.D., Whitlock, C. and Dean, W.E. (2001). Evidence for Millennial-Scale Climate Change During Marine Isotope Stages 2 and 3 at Little Lake, Western Oregon, U.S.A. Quaternary Research, 56(1), $10-22$.

Grigg, L. and Whitlock, C. (2002). Patterns and causes of millennial-scale climate change in the Pacific Northwest during Marine Isotope Stages 2 and 3. Quaternary Science Reviews, 21, 2067-2083.

Harden, J.W., Slate, J.L., Lamothe, P., Chadwick, O., Pendall, E. and Gillespie, A. (1991).Soil formation on the Trail Canyon Alluvial Fan, Fish Lake Valley, Nevada. US Geological Survey Open File Report 91-291.

Hoffmann, D.L. (2008). 230Th isotope measurements of femtogram quantities for U-series dating using multi ion counting (MIC) MC-ICPMS. International Journal of Mass Spectrometry, 275(1-3), 75-79.

Huntington, T. (2006). Evidence for intensification of the global water cycle: Review and synthesis. Journal of Hydrology, 319(1-4), 83-95.

Jewell, P.W. (2007). Morphology and paleoclimatic significance of Pleistocene Lake Bonneville spits. Quaternary Research, 68(3), 421-430.

Jewell, P.W. and Nicoll, K. (2011). Wind regimes and aeolian transport in the Great Basin, U.S.A. Geomorphology, 129(1-2), 1-13. 
Kim, S.J., Crowley, T.J., Erickson, D.J., Govindasamy, B., Duffy, P.B. and Lee, B.Y. (2007). Highresolution climate simulation of the last glacial maximum. Climate Dynamics, 31(1), 1-16.

Krider, P.R. (1998). Paleoclimatic Significance of Late Quaternary Lacustrine and Alluvial Stratigraphy, Animas Valley, New Mexico. Quaternary Research, 50(3), 283-289.

Ku, T.L., Luo, S., Lowenstein, T.K., Li, J. and Spencer, R.J. (1998). U-Series Chronology of Lacustrine Deposits in Death Valley, California. Quaternary Research, 50(3), 261-275.

Ku, T.L. (2000). Uranium-series methods, in Quaternary Geochronology: Methods and Applications, AGU Ref. Shelf, Vol. 4, edited by Noller, J.S., Sowers, J.M. and Lettis, W.R. 101-114.

Lamy, F., Kilian, R., Arz, H.W., Francois, J.P., Kaiser, J., Prange, M. and Steinke, T. (2010). Holocene changes in the position and intensity of the southern westerly wind belt. Nature Geoscience, 3(10), 695-699. Nature Publishing Group.

Laîné,A., Kageyama, M., Salas-Mélia, D., Voldoire, A., Rivière, G., Ramstein, G., Planton, S., et al. (2008). Northern hemisphere storm tracks during the last glacial maximum in the PMIP2 oceanatmosphere coupled models: energetic study, seasonal cycle, precipitation. Climate Dynamics, 32(5), 593-614.

Lerch, D.W., Klemperer, S.L., Egger, A.E., Colgan, J.P. and Miller, E.L. (2010). The northwestern margin of the Basin-and-Range Province, part 1: Reflection profiling of the moderate-angle $\left(\sim 30^{\circ}\right)$ Surprise Valley Fault. Tectonophysics, 488(1-4), 143-149. Elsevier B.V.

Li, H., You, C., Ku, T., Xu, X., Buchheim, H., Wan, N., Wang, R., et al. (2008). Isotopic and geochemical evidence of palaeoclimate changes in Salton Basin, California, during the past $20 \mathrm{kyr}: 2.87 \mathrm{Sr} / 86 \mathrm{Sr}$ ratio in lake tufa as an indicator of connection between Colorado River and Salton Basin. Palaeogeography, Palaeoclimatology, Palaeoecology, 259(2-3), 198-212.

Li, H.C., Xu, X.M., Ku, T.L., You, C.F., Buchheim, H.P. and Peters, R. (2008). Isotopic and geochemical evidence of palaeoclimate changes in Salton Basin, California, during the past $20 \mathrm{kyr}: 1 . \delta 18 \mathrm{O}$ and $\delta 13 \mathrm{C}$ records in lake tufa deposits. Palaeogeography, Palaeoclimatology, Palaeoecology, 259(2-3), 182-197.

Licciardi, J.M. (2001). Chronology of latest Pleistocene lake-level fluctuations in the pluvial Lake Chewaucan basin, Oregon, USA. Journal of Quaternary Science, 16(6), 545-553.

Lin, J.C., Broecker, W.S., Anderson, R.F., Hemming, S., Rubenstone, J.L. and Bonani, G. (1996). New ${ }^{230} \mathrm{Th} / \mathrm{U}$ and ${ }^{14} \mathrm{C}$ ages from Lake Lahontan carbonates, Nevada, USA, and a discussion of the origin of initial thorium. Science, 60(15), 2817-2832.

Liu, Z. (2004). Pleistocene climate evolution in the eastern Pacific and implications for the orbital theory of climate change. Ph.D Thesis. Brown University.

Liu, Z., Altabet, M.A. and Herbert, T.D. (2005). Glacial-interglacial modulation of eastern tropical North Pacific denitrification over the last 1.8-Myr. Geophysical Research Letters, 32(23), 1999-2002.

Ludwig, K. and Titterington, D. (1994). Calculation of isochrons, ages, and errors. Geochimica et Cosmochimica Acta, 58(22), 5031-5042.

Ludwig, K.R. (2003a). Mathematical-statistical treatment of data and errors for 230Th/U geochronology. Uranium-Series Geochemistry. Reviews in Mineralogy and Geochemistry, 52(1), 631-656. 
Ludwig, K.R. (2003b). User's manual for Isoplot 3.00: A geochronological toolkit for microsoft Excel. Berkeley Geochronology Center, Berkeley CA, Special Publication No. 4.

Luo, S., Ku, T.L. (1991). U-series isochron dating: A generalized method employing total-sample dissolution. Geochimica et Cosmochimica Acta, 55, 555-564.

Maher K., Wooden J.L., Paces J.B. and Miller D.M. (2007). ${ }^{230}$ Th-U dating of surficial deposits using the ion microprobe (SHRIMP-RG): a microstratigraphic perspective. Quaternary International, 166, 15 28.

Maher K., Ibarra, D.E., Oster, J.L., Miller, D.M., Redwine, J.L., Reheis, M.C. and Harden, J.H. (in prep). Rainfall and evaporation in the western United States over the last 60,000 years based on U isotopes in soil.

Markgraf, V., Bradbury, J.P., Forester, R.M., Singh, G. and Sternberg, R.S. (1984). San Agustin Plains, New Mexico: age and paleoenvironmental potential reassessed. Quaternary Research. 22(3), 336-343. Elsevier.

Meehl, G., Zwiers, F., Evans, J. and Knutson, T. (2000). Trends in extreme weather and climate events: issues related to modeling extremes in projections of future climate change. Bulletin of the American Meteorological Society, 427-436.

Menking, K.M., Anderson, R.Y., Shafike, N.G., Syed, K.H. and Allen, B.D. (2004). Wetter or colder during the Last Glacial Maximum? Revisiting the pluvial lake question in southwestern North America. Quaternary Research, 62(3), 280-288.

Metcalfe, S. (2002). Wet Conditions during the Last Glaciation in the Chihuahuan Desert, Alta Babicora Basin, Mexico. Quaternary Research, 57(1), 91-101.

Mote, P.W., Hamlet, A.F., Clark, M.P. and Lettenmaier, D.P. (2005). Declining Mountain Snowpack in Western North America. Bulletin of the American Meteorological Society, 86(1), 39-49.

Negrini, R., Erbes, D., Faber, K., Herrera, A., Roberts, A., Cohen, A., Wigand, P., et al. (2000). A paleoclimate record for the past 250,000 years from Summer Lake, Oregon, USA. 1. chronology and magnetic proxies for lake level. Journal of Paleolimnology, 24(2), 125-149.

Neymark, L.A., Paces, J.B., (2000). Consequences of slow growth for Th-230/U dating of Quaternary opals, Yucca Mountain, NV, USA. Chemical Geology, 164, 143-160.

Oldow, J.S. and Singleton, E.S. (2008). Application of Terrestrial Laser Scanning in determining the pattern of late Pleistocene and Holocene fault displacement from the offset of pluvial lake shorelines in the Alvord extensional basin, northern Great Basin, USA. Geosphere, 4(3), 536.

Orme, A.R. (2008). Pleistocene pluvial lakes of the American West: a short history of research. Geological Society, London, Special Publications, 301(1), 51-78.

Oster, J.L., Montañez, I.P., Sharp, W.D. and Cooper, K.M. (2009). Late Pleistocene California droughts during deglaciation and Arctic warming. Earth and Planetary Science Letters, 288(3-4), 434-443. Elsevier.

Oster, J.L., Ibarra, D.E., Harris, C.R. and Maher, K. (in press). Influence of eolian deposition and rainfall amounts on the U-isotopic composition of soil water and soil minerals. Geochimica et Cosmochimica Acta. 
Personius, S.F., Crone, A.J., Machette, M.N., Mahan, S.A. and Lidke, D.J. (2009). Moderate rates of late Quaternary slip along the northwestern margin of the Basin and Range Province, Surprise Valley fault, northeastern California. Journal of Geophysical Research, 114(B9), 1-17.

Rasmussen, S.O., Andersen, K.K., Svensson, A.M., Steffensen, J.P., Vinther, B.M., Clausen, H.B., Siggaard-Andersen, M.L., et al. (2006). A new Greenland ice core chronology for the last glacial termination. Journal of Geophysical Research-Atmospheres 111, DO6102.

Reeder, R.J., Nugent, M., Tait, C.D., Morris, D.E., Heald, S.M., Beck, K.M., Hess, W.P., Lanzirotti, A., (2001). Coprecipitation of uranium(VI) with calcite: XAFS, micro-XAS, and luminescence characterization. Geochimica et Cosmochimica Acta, 65, 3491-3503.

Reheis, M. (1999a). Highest Pluvial-Lake Shorelines and Pleistocene Climate of the Western Great Basin. Quaternary Research, 52(2), 196-205.

Reheis, M.C., (1999b) Extent of Pleistocene lakes in the western Great Basin: U.S. Geological Survey Miscellaneous Field Investigations Map MF-2323 (digital map),

Redwine J. L. (2003). The Quaternary pluvial history and paleoclimate implications of Newark Valley, east-central Nevada; derived from mapping and interpretation of surficial units and geomorphic features. M.S. Thesis, Humboldt State University.

Sack, D. (2002), Fluvial linkages in Lake Bonneville sub-basin integration. Smithsonian Institution Contributions to the Earth Sciences, 33, 129-144.

Salathé, E.P. (2006). Influences of a shift in North Pacific storm tracks on western North American precipitation under global warming. Geophysical Research Letters, 33(19), 1-4.

Schofield, I., Jewell, P., Chan, M., Currey, D. and Gregory, M. (2004). Shoreline development, longshore transport and surface wave dynamics, Pleistocene Lake Bonneville, Utah. Earth Surface Processes and Landforms, 29(13), 1675-1690.

Seager, R., Ting, M., Held, I., Kushnir, Y., Lu, J., Vecchi, G., Huang, H.P., et al. (2007). Model projections of an imminent transition to a more arid climate in southwestern North America. Science, 316(5828), $1181-4$.

Sewall, J.O., Sloan, L.C., (2004). Disappearing Arctic sea ice reduces available water in the American west. Geophysical Research Letters, 31, L06209.

Sharp, W D, Ludwig, K.R., Chadwick, O.A, Amundson, R. and Glaser, L.L. (2003). Dating fluvial terraces by $230 \mathrm{Th} / \mathrm{U}$ on pedogenic carbonate, Wind River Basin, Wyoming. Quaternary Research, 59(2), 139-150.

Sims, K.W.W., Gill, J.B., Dosseto, A., Hoffmann, D.L., Lundstrom, C.C., Williams, R.W., Ball, L., et al . (2008). An Inter-Laboratory Assessment of the Thorium Isotopic Composition of Synthetic and Rock Reference Materials. Geostandards and Geoanalytical Research, 32(1), 65-91.

Tackman, G. (1993). Paleistocene hydrologic history of Diamond Lake with climatic and isostatic implications. Ph.D Thesis. University of Utah.

Talbot, M.R. and Kelts, K. (1990), Paleolimnological signatures from carbon and oxygen isotopic ratios in carbonates from organic carbon-rich lacustrine sediments, in Katz, B., editor, Lacustrine Basin Exploration: Case Studies and Modern Analogs: American Association of Petroleum Geologists Memoir, 50, 99-112. 
Taylor, K.E., Stouffer, R.J. and Meehl, G.A. (2012). An Overview of CMIP5 and the Experiment Design. Bulletin of the American Meteorological Society, 93(4), 485-498.

Toggweiler, J. (2009). Shifting westerlies. Science, 323(5920), 1434-1435. American Association for the Advancement of Science.

Toggweiler, J.R. and Russell, J. (2008). Ocean circulation in a warming climate. Nature, 451(7176), 286-8. doi: $10.1038 /$ nature 06590

Wagner, J.D.M., Cole, J.E., Beck, J.W., Patchett, P.J., Henderson, G.M. and Barnett, H.R. (2010). Moisture variability in the southwestern United States linked to abrupt glacial climate change. Nature Geoscience, 3(2), 110-113. Nature Publishing Group.

Waliser, D., Seo, K.W., Schubert, S. and Njoku, E. (2007). Global water cycle agreement in the climate models assessed in the IPCC AR4. Geophysical Research Letters, 34(16), 1-6.

Walther, G., Post, E., Convey, P. and Menzel, A. (2002). Ecological responses to recent climate change. Nature, 389-395.

Whitlock, C., Sarna-Wojcicki, A., Bartlein, P. and Nickmann, R. (2000). Environmental history and tephrostratigraphy at Carp Lake, southwestern Columbia basin, Washington, USA. Palaeogeography, Palaeoclimatology, Palaeoecology, 155, 7-29.

Winograd, I.J., Landwehr, J.M., Coplen, T.B., Sharp, W.D., Riggs, A.C., Ludwig, K.R., Kolesar, P.T. (2006.) Devils Hole, Nevada, [delta]18O record extended to the mid-Holocene.Quaternary Research, $66,202-212$.

Zic, M. and Negrini, R. (2002). Evidence of synchronous climate change across the Northern Hemisphere between the North Atlantic and the northwestern Great Basin, United States. Geology, 2(7), 635-638.

Zimbelman, J., Garry, W. and Irwin, R. (2009). Precision Topography of Pluvial Features in Western Nevada as Analogs for Possible Pluvial Landforms on Mars. Lunar and Planetary Institute Science Conference Abstracts, 40, 1370. 